\title{
Artificial neural networks and geographic information systems for inland excess water classification
}

\author{
Ph.D. Dissertation
}

Boudewijn van Leeuwen

Supervisors:

Dr. József Szatmári Prof. Dr. Gábor Mezősi

Assistant professor Professor

\section{Earth Sciences Doctoral School}

Department of Physical Geography and Geoinformatics

Faculty of Science and Informatics, University of Szeged

Szeged, 2012 


\section{Table of contents}

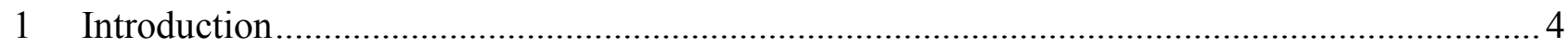

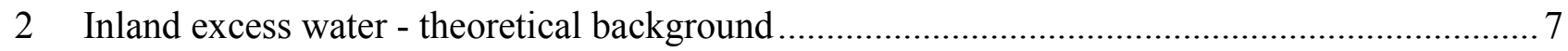

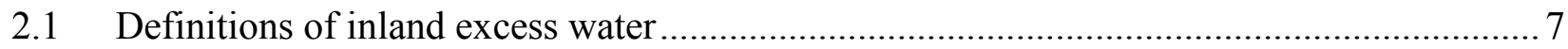

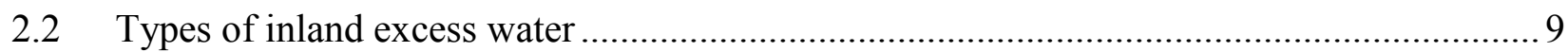

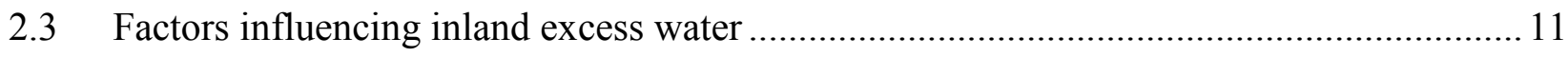

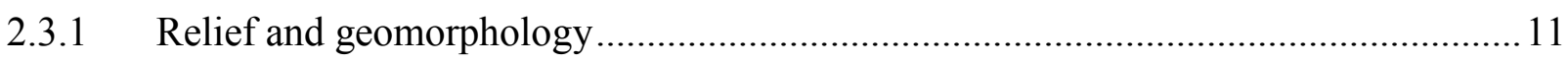

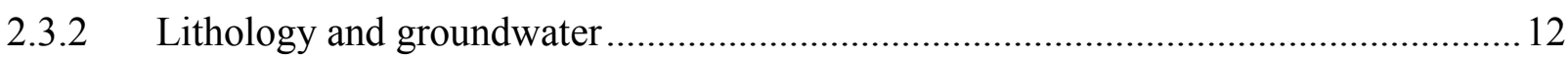

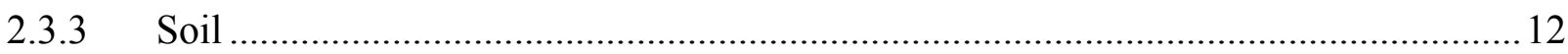

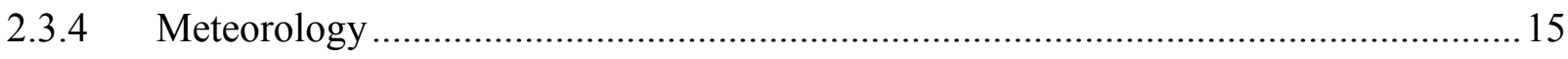

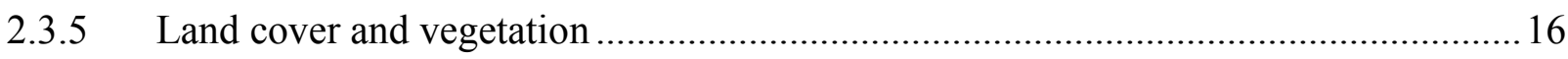

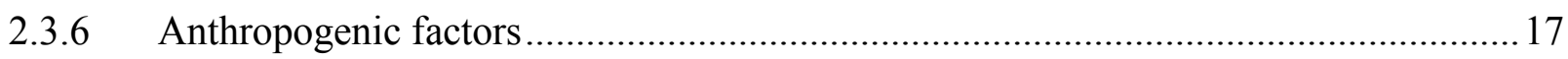

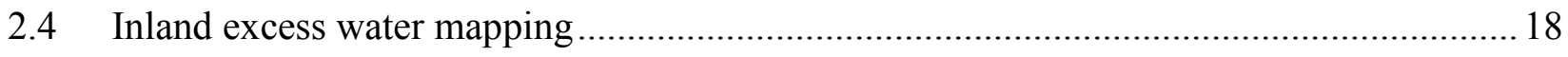

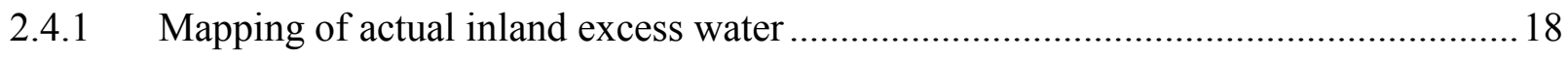

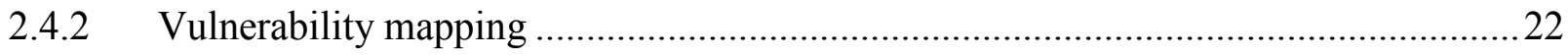

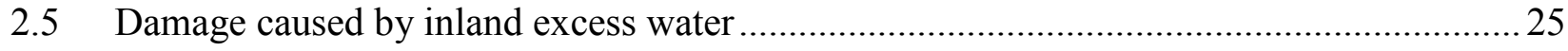

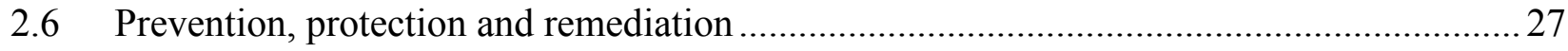

3 Artificial neural networks - theoretical background …………………...................................2 29

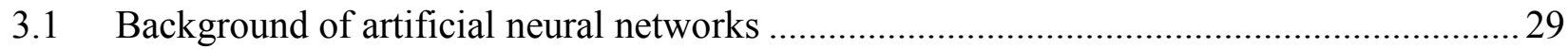

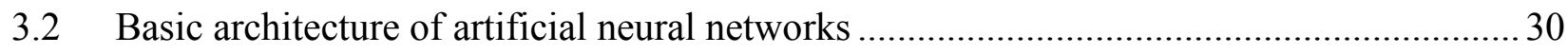

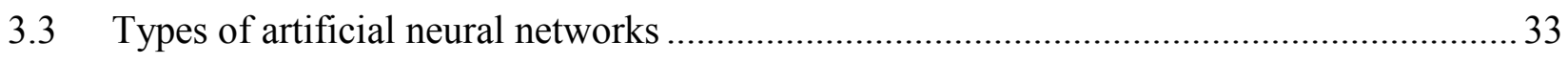

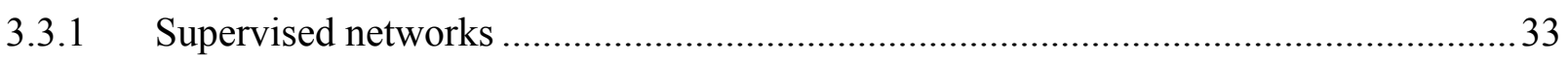

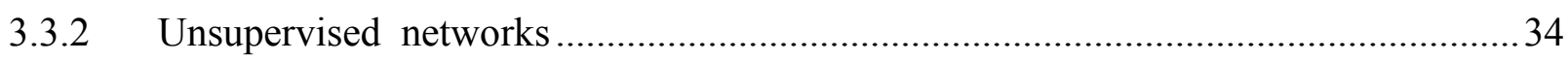

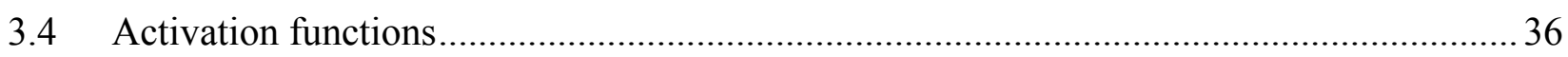

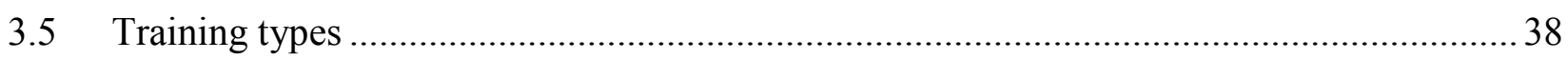

3.6 Application of artificial neural networks in geography and their combination with

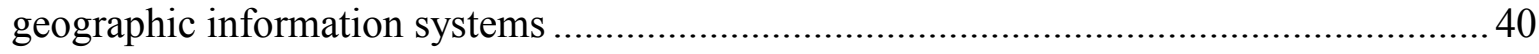

4 Identification and classification of inland excess water ......................................................... 43

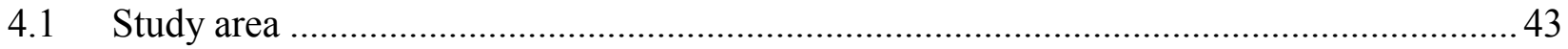

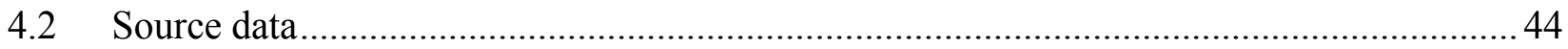

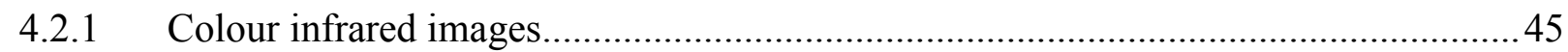

4.2.2 Local depressions derived from a LIDAR based digital elevation model ....................48

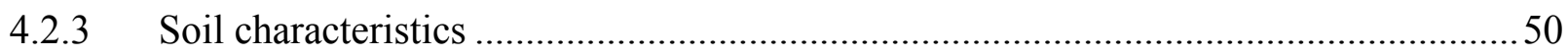

4.2.4 Distance to anthropogenic objects ………………........................................... 


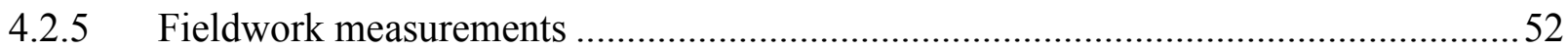

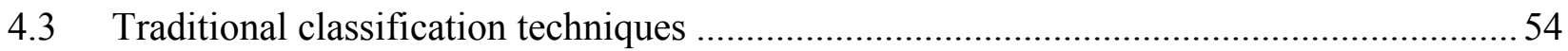

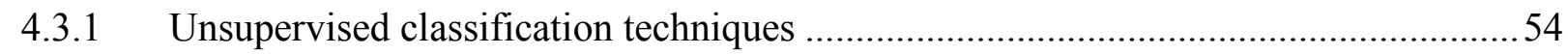

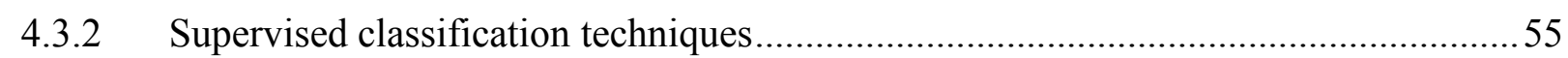

5 Development of an integrated geographic information system - artificial neural

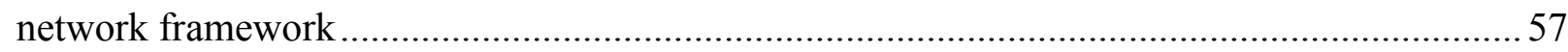

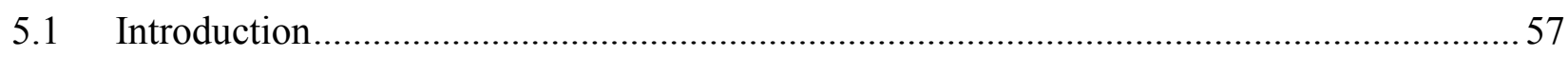

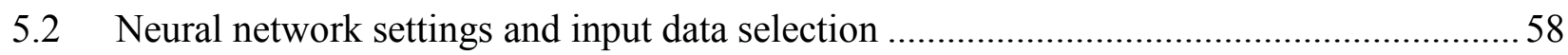

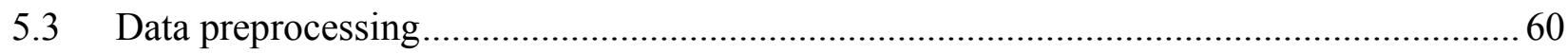

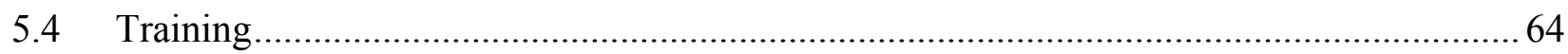

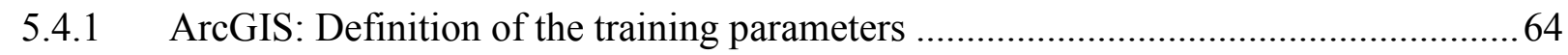

5.4.2 Python: Generation of a command line string for Matlab .......................................65

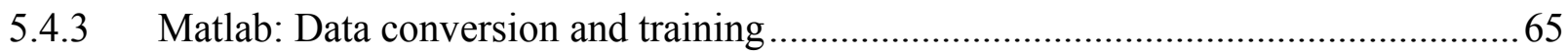

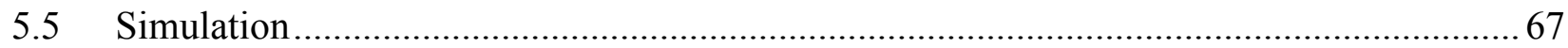

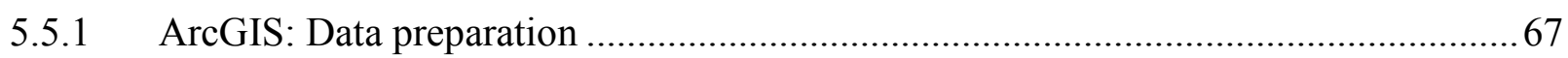

5.5.2 Python: Generation of a command line string for Matlab ........................................6 68

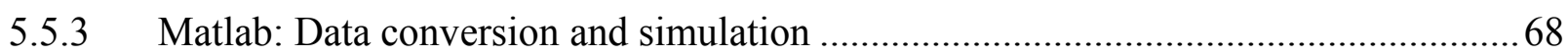

5.5.4 Python: Georeferencing of the simulation output data ............................................69

5.5.5 ArcGIS: Visualization and analysis of the simulation results.....................................69

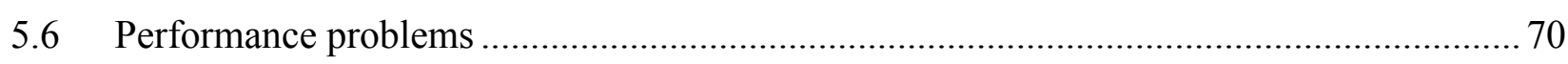

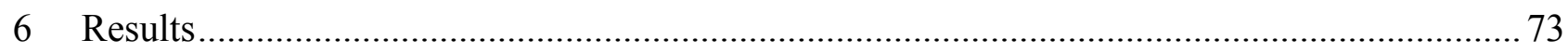

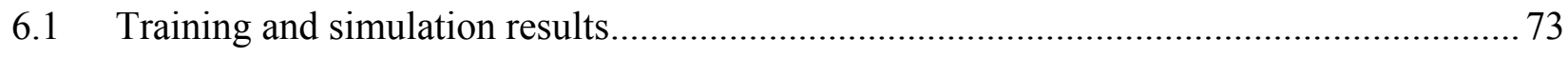

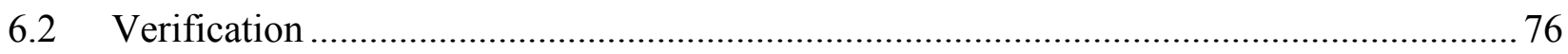

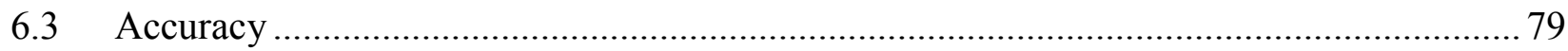

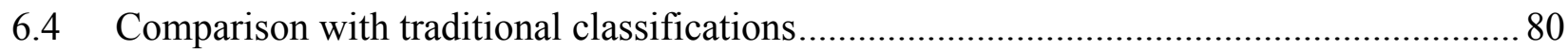

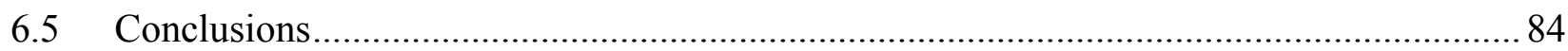

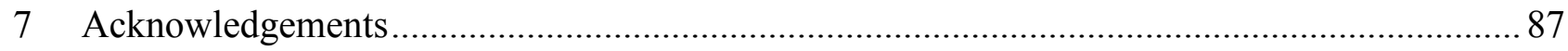

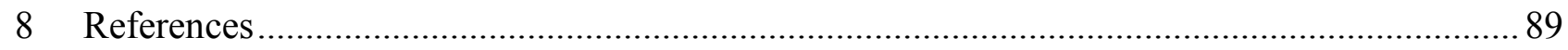

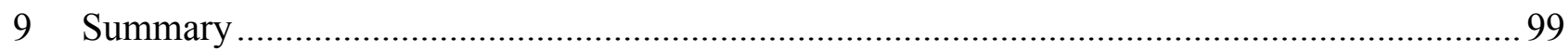

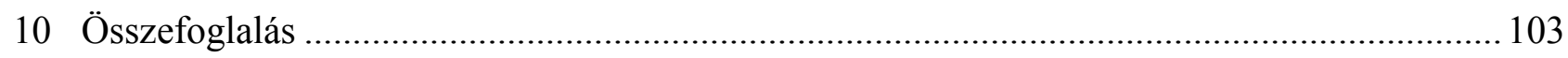

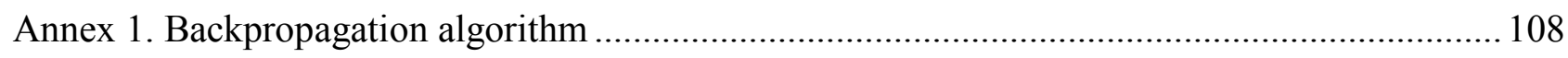

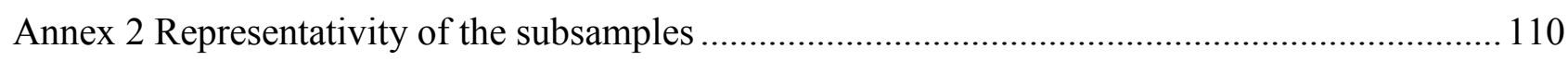

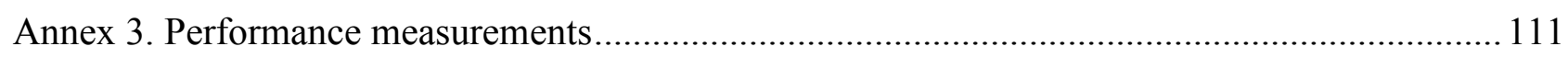




\section{Introduction}

Due to its geographic position and climate, the Great Hungarian Plain is under continuous threat of drought and floods. A well balanced water management program is essential to maintain and improve the water balance on the Hungarian landscape. On one hand, hot summers with limited precipitation result in severe aridification of the landscape (Pálfai 2011, Ladányi et al. 2011, Várallyay et al. 1980), while on the other hand, periods of extensive rainfall and snow melting cause large areas to be flooded. Apart from floodings from rivers, inland excess water (Fig. 1.1) is a reoccurring problem on the Great Hungarian Plain with major economic and environmental consequences.
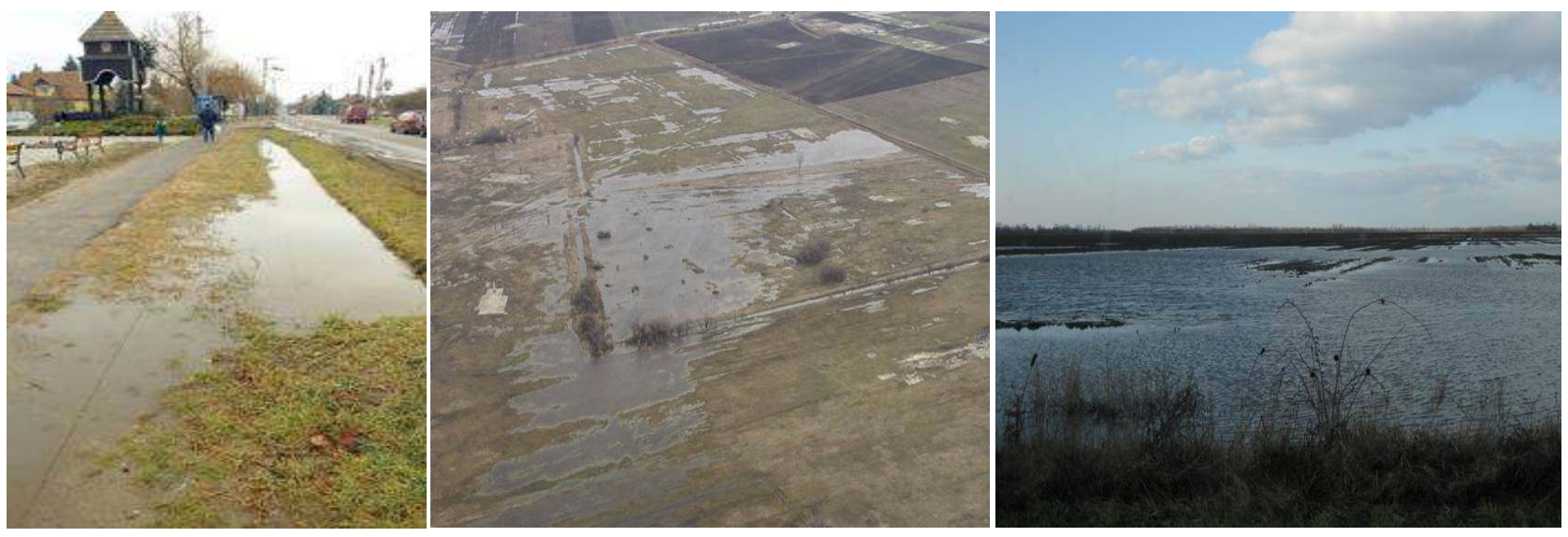

Figure 1.1 Inland excess water within the city (left) and on the countryside (March 2006 in the center, February 2010: on the right)

The amount of inland excess water inundations is strongly fluctuating (Fig. 1.2). On average, in Hungary, every year 110000 ha of land is covered with water, but since 1935 there have been 10 years with less than 10000 ha, and 13 years with more than 200000 ha of land covered with water.

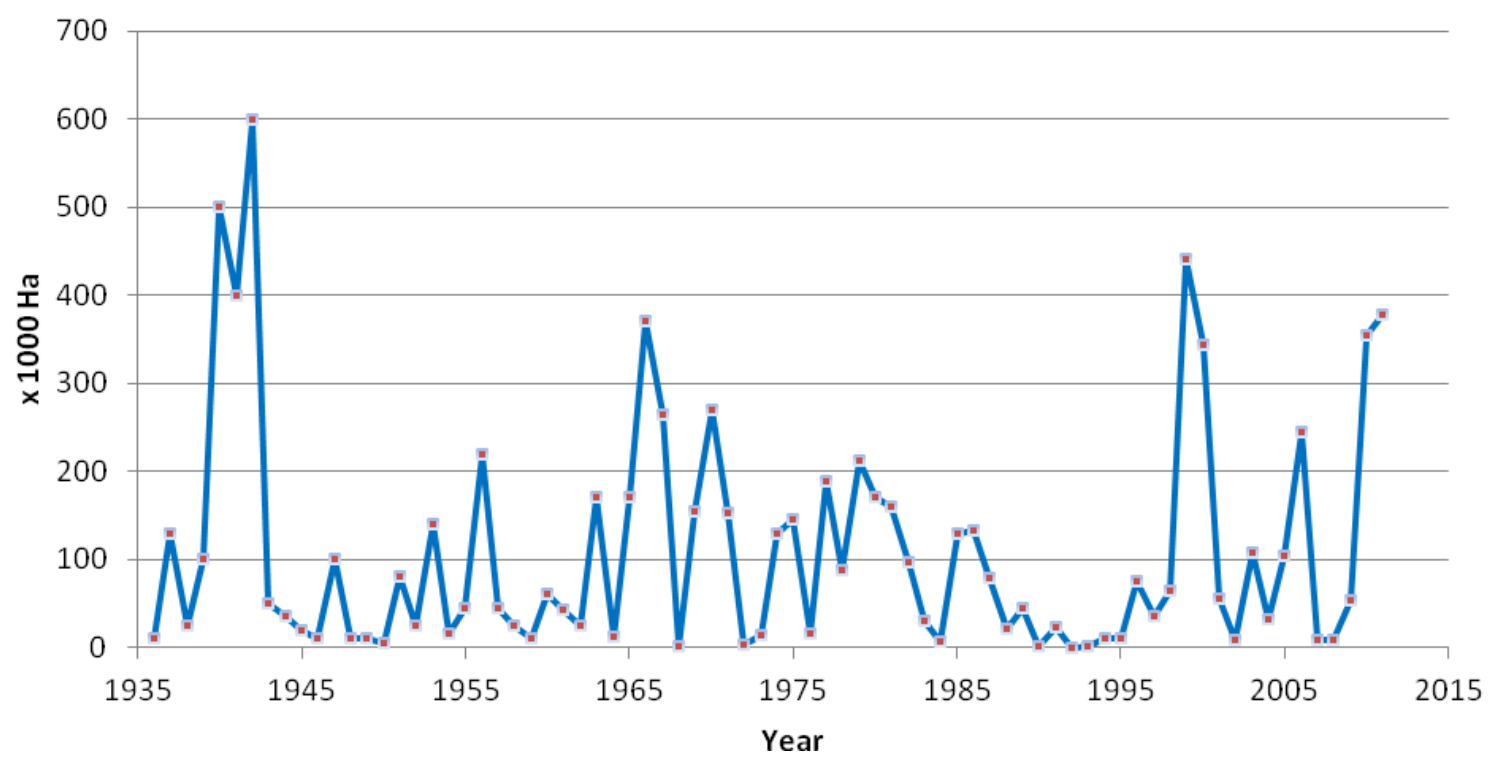

Figure 1.2 Area covered by inland excess water between 1935 and 2011. Except for the year 1940-1944, the inundations from before 1950 are estimates (Source: Vizugy 2011, Pálfai 2000) 
The year 2010 was one of the wettest years ever in Hungary. In the period October 2009 December 2010, on the Great Hungarian Plain, $1149 \mathrm{~mm}$ of precipitation fell, which corresponds to a yearly precipitation of $919 \mathrm{~mm}$, while the long term average yearly precipitation is $489 \mathrm{~mm}$ (in Szeged, OMSz 2012). The extreme precipitation caused exceptionally large areas to be flooded by inland excess water. The maximum total area that was flooded was 355000 ha (Vízügy 2011) and the estimated financial damage to the agriculture alone exceeded 500 million Euros (Agrárszektor 2011). During January and February 2011, the area flooded by inland excess water increased further to the maximum of 380000 ha on January 15, 2011 (Vízügy 2011), which is about 11\% of the total of agricultural land in the country.

Many studies have analysed the inland excess water problem, with varying success (Bozán et al. 2005, Pálfai 2004b, Pásztor et al. 2006, Rakonczai et al. 2001, Rakonczai et al. 2003, Thyll \& Bíró 1999). Most studies have tried to identify phenomena that cause the inland excess water and combined them using regression functions or other linear statistical methods. These methods have the disadvantage that they can neither deal with nonlinear and complex functional relationships nor with collinearity between variables (Lakes et al. 2009, Atkinson \& Tatnall 1997). In this dissertation, I propose a different approach using artificial neural networks (ANN) combined with geographic information systems (GIS). This approach has many advantages over other statistical methods. First, it is independent of the statistical distribution of the data, and there is no need for specific statistical variables. Neural networks allow the target classes to be defined in relation to their distribution in the corresponding domain of each data source, and therefore the integration of remote sensing and GIS data is very convenient (Pradhan \& Lee 2010a). Furthermore, ANNs are capable of incorporating uncertainty, incomplete data, incorrect sampling, multicollinearity between variables, spatial or temporal autocorrelation, and insignificance of single variables (Bishop 1995, Yang \& Rosenbaum 2001). These are common in geographic analysis, but especially in inland excess water research due to the fuzzy nature of the boundaries of the inundations and the complex interrelations between the factors that cause inland excess water.

Certain types of inland excess water can be forecast and those areas where action is needed for decreasing or even avoiding damage can be directly determined with the help of theoretical and practical means. This way the risk of inundations can be mitigated, and this could lead to a shift from a re-active defensive-type water management strategy towards a more pro-active strategy.

ANNs have proven themselves in many fields of science where complex data sets need to be analyzed to identify their underlying structures and properties. Neural networks have a large potential for analysis of complex spatial problems which are common in geographic research (Hewitson \& Crane 1994, Atkinson \& Tatnall 1997). Inland excess water inundations on the Great Hungarian Plain are a clear example of such problems. The reoccurring inundations are caused by a multitude of interrelated factors. 
Combining artificial neural networks with a geographic information system into one framework has the great advantage that the spatial analysis functionality is efficiently combined with the nonlinear classification capability of the networks.

The aim of this work is to connect artificial neural network methods to a geographic information system with the aim to classify inland excess water occurrences in an effective and efficient way. 


\section{Inland excess water - theoretical background}

The world's hydrological cycle is a closed system where water is recycled over and over again in, on and above the Earth's surface (Fig. 2.1). Water is continuously changing its state and position in this cycle. It can be found in solid, liquid and gaseous form. It can remain at a certain position for a very short period, like in a river or for much longer periods when it is stored in for example an icecap. Physical processes, like evaporation, infiltration or sub-surface flow allow water to move from one type of reservoir to another.

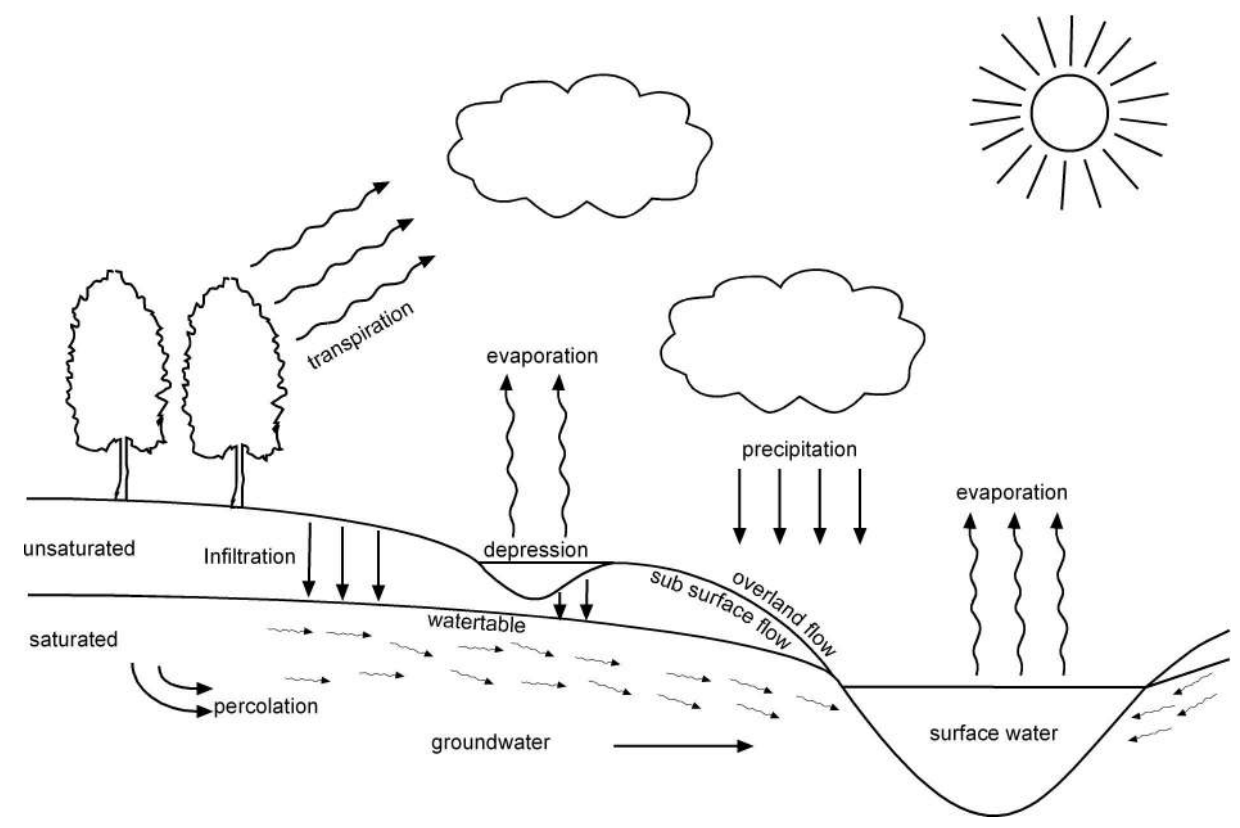

Figure 2.1 Hydrological cycle

Water management in the Carpathian basin has two basic opposing components, namely discharge of surplus water and complementation of water shortage. Both components vary greatly in time and place (Várallyay et al. 1980). Due to the warm summers and poor storing capacity of soils in many places severe droughts occur. On the contrary, due to snow melting at the end of the winter, high groundwater levels, low relief intensity, bad infiltration capacity of the soils, and high intensity precipitation at the beginning of the summer, large areas suffer from inland excess water which causes serious financial, environmental and social problems.

\subsection{Definitions of inland excess water}

There is no formal or official English word to describe the hydrological process that is the main topic of this work. Inland excess water is a translation of the Hungarian word belviz and will be used throughout this work. In literature, both excess water and inland water can be found as well, but are not used here since inland water may cover any type of water that is not sea or ocean, while excess water may also describe inundations by flooded rivers. Kuti - after "consultation with several experts" - uses excess water inundation (Kuti 2006). This term still seems to cover river floodings 
as well. Standing water or sitting water are terms that are usually used for smaller areas, up to about $100 \mathrm{~m}^{2}$ that are temporarily covered by water. In German, the terms polderwasser and stauwasser are used (Kozák 2006). Although inland excess water got most scientific attention in Hungary, the phenomenon is not limited to this geographic region. For example, in China, Germany, India, Italy, the Netherlands, Serbia, Romania and Russia, it occurs as well (Kuti 2006, Pálfai 2004b). In other countries, inland excess water is usually regarded as a specific type of flooding and not recognized as a separate physical process.

Palfai collected over 50 different definitions for inland excess water or belviz (Palfai 2001). This large amount of definitions reflects the different scientific fields that deal with inland excess water (Kozák 2011, Vámosi 2002). Every field e.g. water management, agriculture, ecology, landscape planning or economics defines inland excess water from its own perspective. Most definitions though have a common base where inland excess water is defined as surplus water (from precipitation, snow melting or groundwater) that does not disappear from the land in a short period due to insufficient evaporation, infiltration or runoff. From an ecological point of view, inland excess water does not only occur on the surface but may - if it causes harm to vegetation - also cover completely saturated soil (Rakonczai et al. 2011, Körösparti \& Bozán 2008). Many other definitions also describe inland excess water as a phenomenon that causes damage to the anthropogenic and/or natural environment. Although, in most cases the inundations do cause extensive damage, in this work, this is not considered a prerequisite for inundations to be defined as inland excess water.

Inland excess water is a topic that has been studied by many different disciplines. Many authors developed methods to estimate the risk of flooding (Pálfai et al. 2004a, Bozán et al. 2005, Thyll \& Bíró 1999, Pásztor et al. 2006, Koncsos \& Balogh 2009, Körösparti et al. 2009). Others used remote sensing data and techniques to identify inundations (Csekő 2003, Csornai et al. 2000, Rakonczai et al. 2001, Licskó 2009, Mucsi \& Henits 2011, Szatmári et al. 2011b), Farsang (2011) studied the role soil characteristics play in the development of inland excess water. Vámosi discussed its influence on land use planning (Vámosi 2002). Inland excess water has been described from a theoretical point of view by Pálfai (2004b) and Rakonczai et al. (2011).

The engineering approach is the most common way to look at the problem of inland excess water. The main topic of this approach is how to calculate the amount and size of channels needed to discharge inland excess water. The question is handled by calculating the standard discharge or the water discharge capacity. Pálfai identified 7 methods to calculate or estimate these. He compared the results of the discharge calculations for a test area and found that they vary by $25-30 \%$ from each other (Pálfai 2004b). 


\subsection{Types of inland excess water}

Different genetic types of inland excess water can be distinguished (Kozák 2006, Pálfai 2001, Pásztor et al. 2006, Rakonczai et al. 2011, Vágás 1989). The first type is the vertical or upwelling type, which is caused by the upwards push of groundwater (Fig. 2.2).

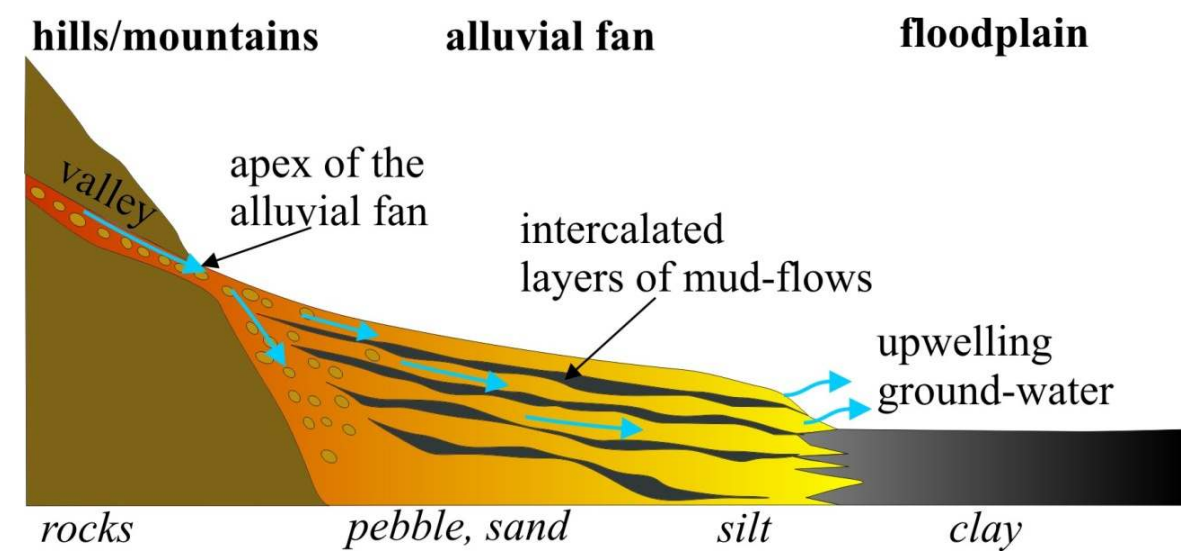

Figure 2.2 Vertical or upwelling inland excess water (source: Strahler 1975, adapted by T. Kiss)

The vertical type occurs where groundwater flows from higher areas towards lower areas, where it appears on the surface by leakage through porous soil. This normally occurs at the edges of alluvial fans and between ridges in the middle of the fan.

The second genetic type of inland excess water - the horizontal or accumulative one - finds its origin in precipitation. Due to rainfall, snow or melting of the snow or of the top soil layer, a large amount of water suddenly appears on the surface. If this surplus water can neither evaporate nor infiltrate in the soil, it will accumulate under gravity in the lowest areas (Fig. 2.3). If the slope is gentile and the height differences are small, no gullies, stream and rivers are formed to transport the water away. The slow overland flow accumulates in local depressions.

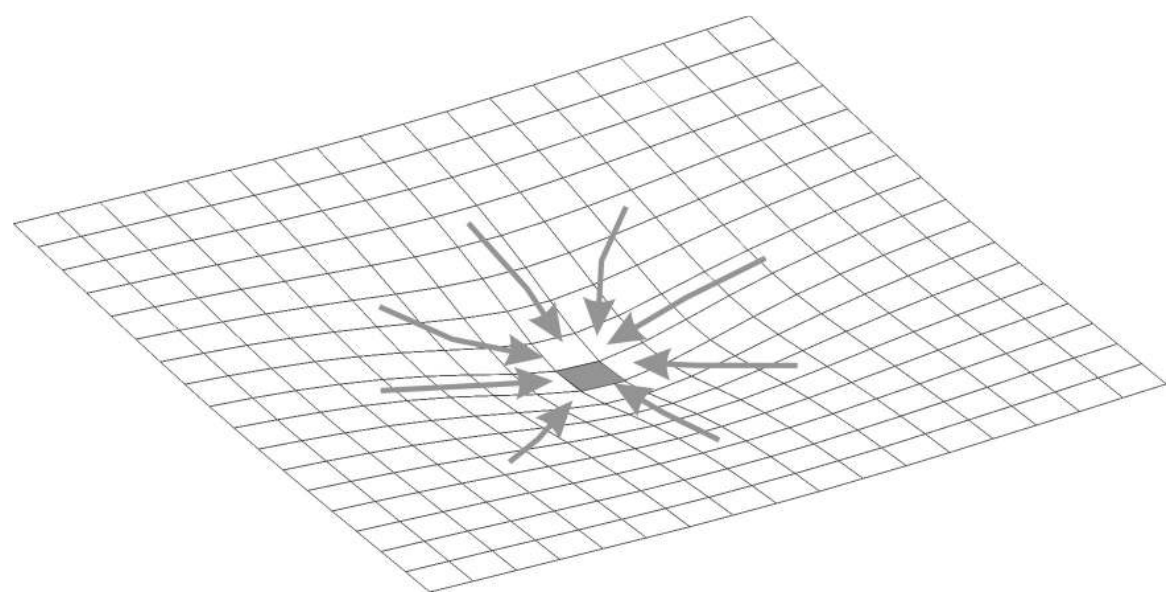

Figure 2.3 Horizontal or accumulative inland excess water 
A third type of inland excess water is summarized by Rakonczai et al. (2011) and based on Vágás 1989). This type has an anthropogenic origin since it results from insufficient pumping capacity. From different areas, inland excess water is transported away via a system of channels towards a pumping station which pumps the water into a main river. If the capacity of the pumping station is not sufficient to immediately pump away the water, the water will queue up in front of the pumping station, and causes the lowest areas surrounding the channels to be flooded (Fig. 2.4.).

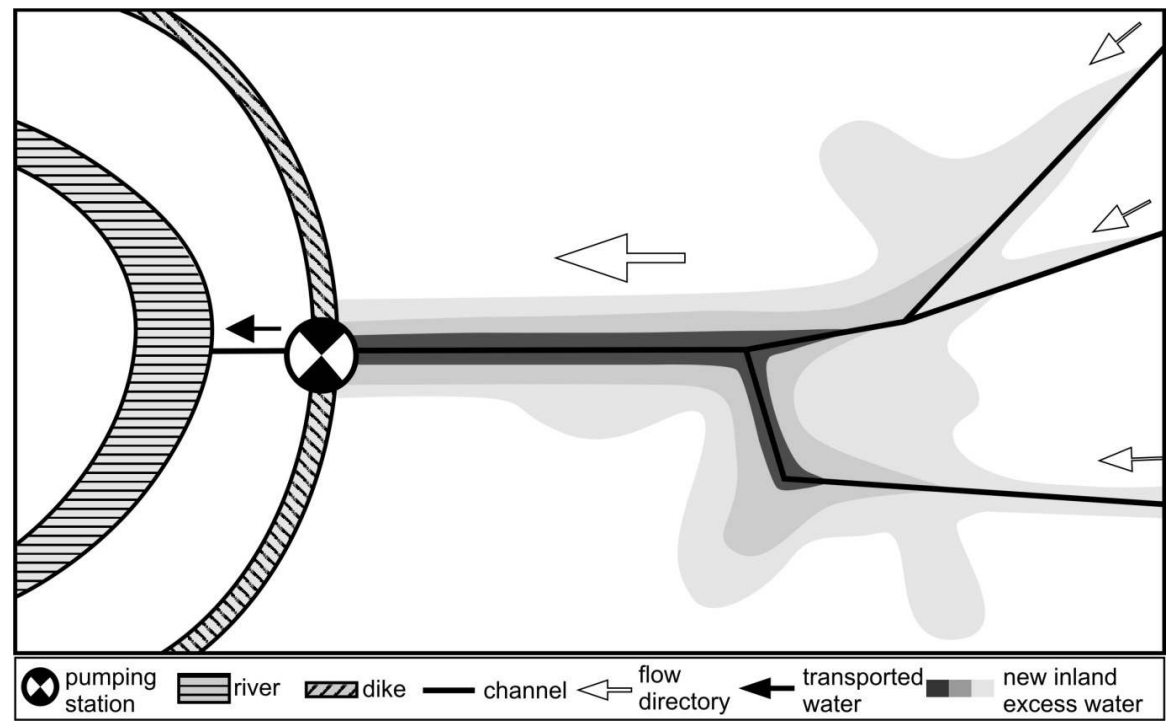

Figure 2.4 Inundation due to queuing up of inland excess water transportation (Rakonczai et al. 2011)

All types of inland excess water cause local depressions to be filled with water. Depending on the meteorological conditions, soil characteristics and human interaction, this water can disappear. Kozák (2011) presented figures about the ratio between these for the 2010 - 2011 inland excess water period. In the area of the Directorate for Environmental Protection and Water Management of Lower Tisza District (ATIKÖVIZIG), the maximum amount of area covered by water was 87850 ha on January 16, 2011. These inundations disappeared via evaporation (78 \%), infiltration (8\%) and human intervention (pumping away) (14\%). The infiltration figures were low due to the fact that the soil was already saturated with water due to earlier inland excess water periods. Also normal runoff towards rivers was not possible due to the high water levels in those rivers.

Inland excess water usually happens from December till April, when lots of snow melts and severe precipitation occurs. In this period, the largest inundations occur, but this does not always result in big economic loss because of minimal agricultural activity in this period. The summer inland excess water - happening from June until August, and caused by short periods of very intensive rainfall or longer periods of low intensity rainfall - often results in larger economic damage due to the crop losses. The autumn inland excess water is caused by high intensity rainfall, but is not that common since in this period the infiltration and storage capacity of the soil are larger due to the earlier drier periods. 
In this research, inland excess water is treated from a natural (geo)science point of view. Therefore, the general working definition that will be used throughout this work is the following:

Inland excess water is water that temporarily remains in local depressions because of a combination of a surplus of water due to lack of runoff, insufficient evaporation and low infiltration capacity of the soil or because of upwelling of groundwater.

\subsection{Factors influencing inland excess water}

Factors that influence the development of inland excess water can be split into two groups. The static factors are phenomena that are stable over a period of decades or longer. Examples are relief and soil. They change very slowly compared to dynamic factors like meteorology or groundwater levels that could change within hours or days.

\subsubsection{Relief and geomorphology}

The most important static factor in the development of inland excess water is the relief. Only in regions with low relief intensity, water will collect in relatively small and local depressions. In regions with larger height differences, water accumulates in gullies, streams and rivers and inland excess water does not occur.

In flat regions, meandering of rivers is a dominant geomorphological process. Former meanders are often only several tens of centimeters lower than the surroundings, and are not visible during dry periods, but when they get inundated by inland excess water they can be clearly identified (Rakonczai et al. 2011) (Fig 2.5.).
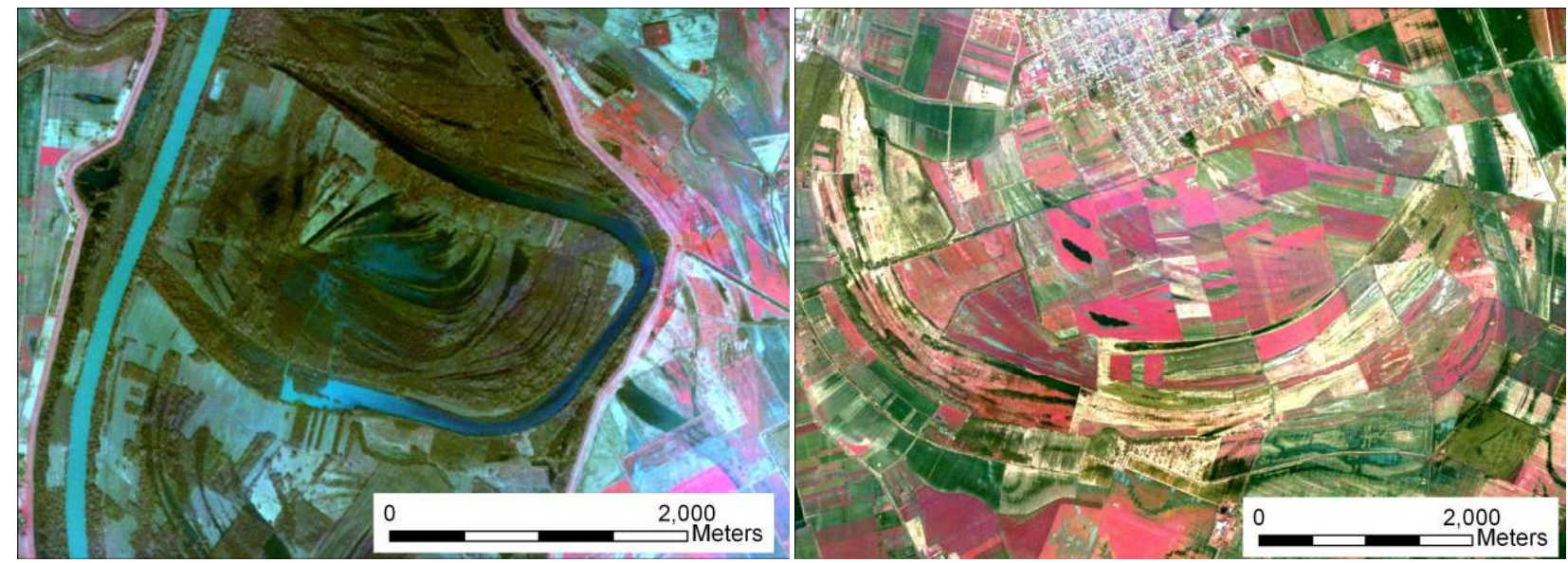

Figure 2.5 RapidEye false colour composite satellite images (24 march 2011) showing former meanders with inland excess water; left: Tisza-holtág, Mártélyi environmental protection area, and right: Desk

The geomorphology also determines the shape of inland excess water patches. Patay and Montvajszki (2010) defined 5 geometrical shapes that are directly related to the geomorphological patterns in the terrain (Fig. 2.6.). 


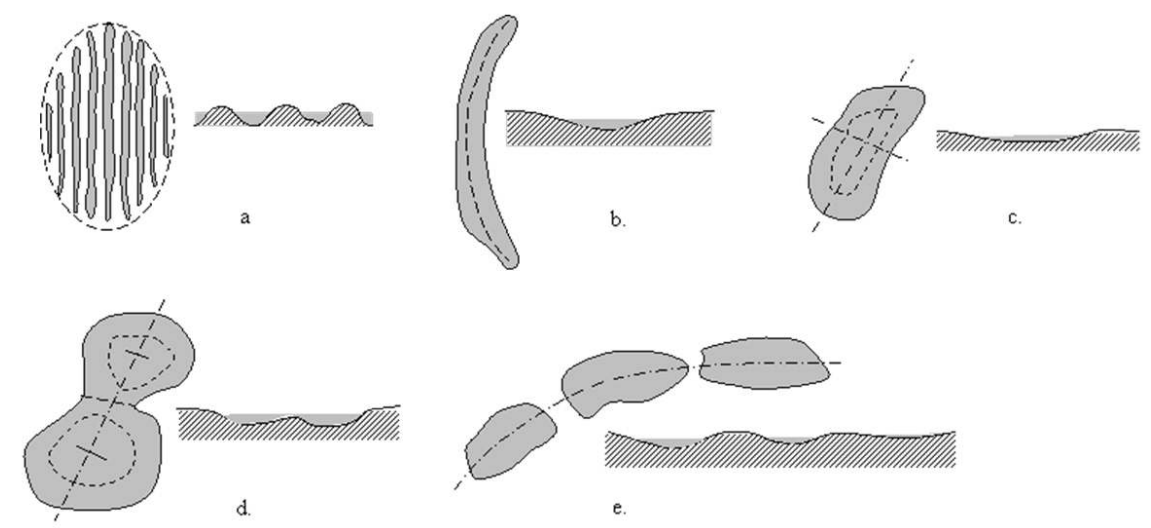

Figure 2.6 Geometrical shapes of inland excess water (after Patay \& Montvajszki (2010)). a) Ploughing grooves type, due to ploughing long and narrow parallel grooves that fill with water, b) Ditch type, long stretched parts that are suddenly lower than the surroundings (often filled up trenches, remainings of channels), c) Pool type, circular or oval shaped depressions, with one central deepest point, d) Twin pool type, connected pool type depressions, that are separated from each other by a levee under water. The depth of the separate pools is usually not equal. e) Rosary type, a chain of pool type depressions that normally result from a former river bed or oxbow

\subsubsection{Lithology and groundwater}

The role groundwater plays in the formation of inland excess water is closely linked to other factors like soil, relief, lithology, geomorphology and precipitation. In multiple ways, the hydro-geological situation can influence the formation of inland excess water (Kozák 2006, Rakonczai et al. 2011). First, when a watertight rock formation is close to the surface, (rain)water will not be able to infiltrate deeper than the shallow soil layer on top of the rock formation, and the soil gets saturated quickly. Second, when sediments easily allow for the horizontal movement of water, upwelling inland excess water develops at locations where groundwater appears on the surface in local depressions (see $\S 2.2$ ) or at places where there is a sudden decrease in height (e.g. at the border of an alluvial fan, at a channel incision). Furthermore, in areas where groundwater is close to the surface, small variations in groundwater level may lead to inland excess water.

Inland excess water can also have a positive effect on the groundwater table. After a period of draught, properly managed inland excess water can be used to recharge the groundwater balance (Rakonczai et al. 2011).

\subsubsection{Soil}

Soils play a major role in the water balance and the prevention or occurrence of inland excess water. Characteristics of the soil determine the infiltration capacity/rate as well as the storage capacity (Várallyay et al 1979, 1980). The average yearly precipitation in Hungary accumulates $50-55 \mathrm{~km}^{3}$ of water, while the soil has a potential storage capacity of $25-35 \mathrm{~km}^{3}$ (Farsang 2011, Szabó et al. 2000). About $60 \%$ of this volume is dead water, which is trapped in the soil at depths where it is not available for vegetation (Várallyay 2010). The major characteristics of the Hungarian soil types and their sensitivity to inland excess water are shown in table 2.1 . 
Table 2.1. General soil types in Hungary and their characteristics relevant to inland excess water. Based on Körösparti et al. (2009) and Várallyay et al. (1980), who used the standard Kreybig type classification (Kreybig 1956) to reclassify the soils according to their water household characteristics

\begin{tabular}{|c|c|c|c|c|c|c|}
\hline $\begin{array}{l}\text { Soil categories, } \\
\text { according to } \\
\text { physical } \\
\text { characteristics }\end{array}$ & $\begin{array}{l}\text { Soil-water } \\
\text { category }^{*}\end{array}$ & $\begin{array}{l}\text { Infiltration } \\
\text { rate } \\
(\mathrm{mm} / \text { hour) }\end{array}$ & $\begin{array}{l}\text { Hydraulic } \\
\text { conductivity } \\
\text { (mm/hour) }\end{array}$ & $\begin{array}{l}\text { Plasticity } \\
\text { index } \\
\text { according } \\
\text { to Arany } \\
\left(K_{A}\right)\end{array}$ & $\begin{array}{l}\text { Kreybig } \\
\text { category }\end{array}$ & $\begin{array}{c}\text { Sensitivity } \\
\text { to inland } \\
\text { excess } \\
\text { water }\end{array}$ \\
\hline Sand & $\begin{array}{l}\text { Very high IR, } \mathrm{P} \text { and } \\
\mathrm{HC} \text {, low FC; and } \\
\text { very poor WR }\end{array}$ & 500 & 40 & $<30$ & V & \multirow{4}{*}{$\begin{array}{c}\text { Not } \\
\text { sensitive }\end{array}$} \\
\hline Sandy loam & $\begin{array}{l}\text { High IR, P and HC; } \\
\text { medium FC; and poor } \\
\text { WR }\end{array}$ & 325 & $25-30$ & $30-38$ & IV & \\
\hline Silt & $\begin{array}{l}\text { Good IR, P and HC, } \\
\text { good FC; and good } \\
\text { WR }\end{array}$ & 125 & $15-30$ & $38-42$ & I & \\
\hline Clayey loam & $\begin{array}{l}\text { Moderate IR, P, HC, } \\
\text { high FC; and good } \\
\text { WR }\end{array}$ & 85 & $10-15$ & $42-50$ & II & \\
\hline Clay & $\begin{array}{l}\text { Moderate IR, poor P } \\
\text { and HC, high FC; and } \\
\text { high WR }\end{array}$ & 60 & 10 & $50-60$ & II (VI) & $\begin{array}{c}\text { Very } \\
\text { sensitive }\end{array}$ \\
\hline
\end{tabular}

*IR: infiltration rate, P: permeability, HC: hydraulic conductivity, FC: field capacity, WR: water retention

Apart from the water that is chemically stored within the soil particles, the storage capacity of the soil is determined by its texture; resulting in a high storage capacity of clay, and lower storage capacity of sand, depending on the void volume (space between the particles). The soil structure determines the infiltration capacity. The high density of clayish soils can impede water from infiltration. This type of soil combined with insufficient runoff and evapotranspiration results in formation of inland excess water of the horizontal type (see $\S 2.2$ ). Coarse soil structures, like in sandy soils, have very good infiltration capabilities, but there, water may percolate to deeper soil layers fast. If there is enough storage capacity in the soil the groundwater level will not increase, and the vertical type of inland excess water is unlikely to occur. If the soil structure is very course, the soil may dry out easily during periods of drought.

Different phenomena can cause the soils to have a positive effect on the formation of inland excess water (Fig. 2.7). 


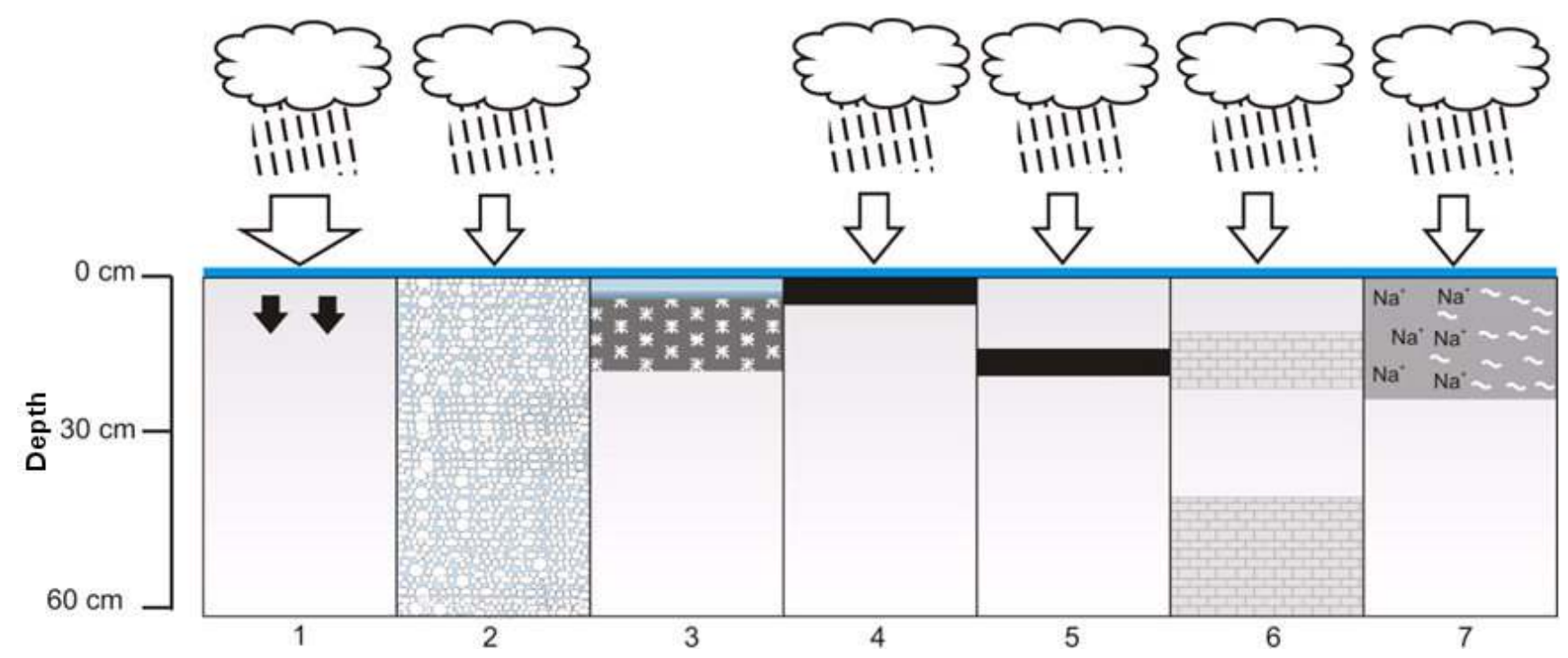

Figure 2.7 Pedological causes of inland excess water: 1) The soil is free of degradation but the infiltration capacity is lower than the precipitation intensity, 2) The soil has a limited infiltration capacity because it is saturated by water, 3) Due to the frozen topsoil, infiltration is not possible, 4) A compact impermeable layer has formed on the surface or in the upper layer of the soil due to continuous external pressure on the soil (by agricultural vehicles, animals, etc). Even with small amounts of precipitation inland excess water can occur on these soils. 5) Soils with a compact impermeable soil layer (clayey) near to the surface or soil degradation (compaction) caused by inadequate landuse and tillage (plough pan). 6) Soils with an extreme moisture regime due to an impermeable layer (cemented by ironstone, calcium carbonate or gypsum) in the upper soil layer and lower. Among others, the compact soils with high clay content on the Great Hungarian Plain belong to this type. 7) Soils with an extremely unfavourable water management due to high salinity/sodicity and/or clay accumulation in the B horizon. (Based on Farsang 2011 and Rakonzcai et al. 2011)

In any soil type after heavy rainfall, inland excess water may occur in local depressions when the soil is (nearly) saturated with water. For example after the extensive rainfall of the summer of 1999 , significant inundations also occured on sandy soils (Kozák 2006). Even if the physical and chemical composition of the soil is without problems, anthropogenic influence can cause inland excess water. These influences are discussed in $\S 2.3 .6$.

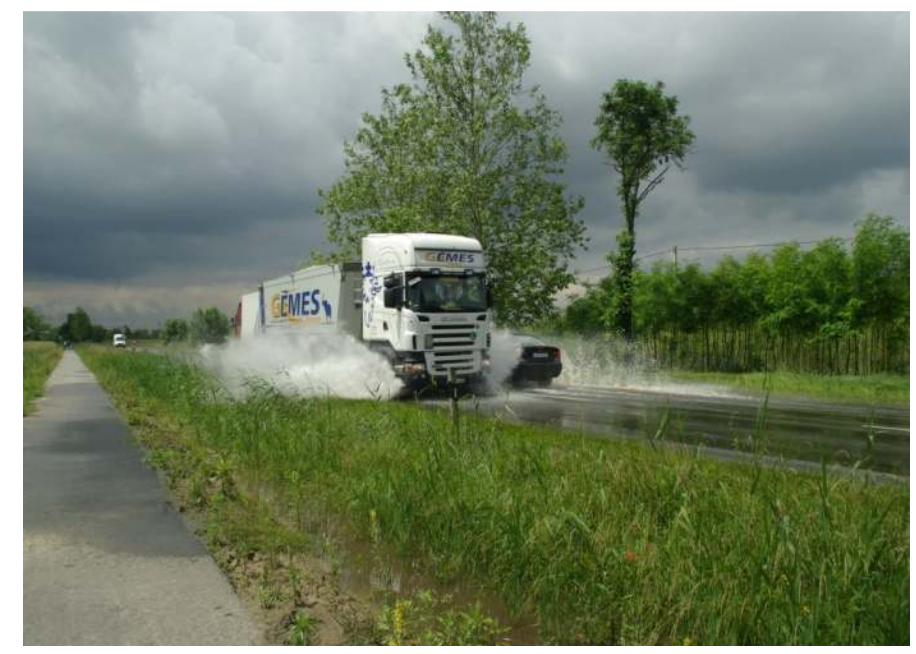

Figure 2.8 Inland excess water in 2010 near Mórahalom, Hungary (Source: J. Rakonczai) 
An example of soil characteristics resulting in the formation of inland excess water is shown in figure 2.8, where an impermeable fresh water limestone layer at a depth of 50-60 cm prevents infiltration of water to the lower soil layers.

\subsubsection{Meteorology}

The meteorological factor is the determining dynamic factor in the formation of inland excess water. It consists of several components like precipitation, temperature, relative humidity and wind speed.

Precipitation in the form of snow and rain provides the source for inland excess water. Apart from the amount of water, the intensity and the interval are important as well. Short rain showers with high intensity may cause inland excess water because water cannot infiltrate in the soil fast enough, and long periods of low intensity rainfall can saturate the top layer of the soil. Equal amounts of precipitation may result in different extents of inland excess water if they were preceded by a dry or a wet period. Also a (partly) frozen soil layer, due to a cold period ahead of a rainy period results in more inland excess water.

Pálfai analyzed the relation between precipitation and the occurrences of inland excess water between 1951 and 2010 in the lower Tisza region. He found that in periods without inundations also the average yearly precipitation was low. The relationship between the amount of hectares covered with inland excess water and the wet years is not strong; there were several occasions when the precipitation was well above average, but no extreme inland excess water situation occurred. In most cases this was the result of a long period of severe drought ahead of the precipitation period (Pálfai 2011).

The meteorological factor in the form of precipitation does not just play an important role as source of the surplus water; solar radiation, air temperature, relative humidity and wind speed determine the evapotranspiration rate (Allen et al. 1998) and as such help to reduce the inundations. If there is no natural runoff and the infiltration rate of the soil in inland excess water areas is very low, evapotranspiration is the only way the water can disappear.

When the air temperature is higher, more evapotranspiration occurs, but the inland excess water itself also warms up. Experimental studies have shown that warmer water is more harmful to flooded plants than cold water (Kreybig 1956, Kozák 2006).

When temperatures are below zero, water in and on the soil, and in channels will freeze. Frozen soil is impermeable and even when the temperature is rising, first the upper few centimeters of soil will unfreeze causing extra water, and new precipitation will still not be able to infiltrate. Due to vegetation or a low sun angle, ice in channels often melts slower than ice on the surface, directly exposed to the sun. This may result in channels to be stuck with ice preventing melted water and/or new precipitation from being transported away. This may cause new inland excess water. 
Solar radiation is the energy source for the evapotranspiration process. Apart from the relative position of the earth towards the sun, the amount of sunlight also depends of on atmospheric conditions, like turbulence and clouds. The relative humidity influences the evapotranspiration rate in a negative way; the higher the relative humidity, the higher the water vapour pressure and the lower the evapotranspiration rate. Wind influences the evapotranspiration rate positively. Higher wind velocity increases the water vapour removal. The wind continuously removes air that is saturated with water vapour by the evapotranspiration process, to make room for drier air that can hold more water vapour.

Different methods exist to measure evapotranspiration. Direct measurement techniques, like with a lysimeter (Barta 2012) can be applied if the area is relatively small. If evapotranspiration estimations over larger regions are required, techniques based on thermal satellite or airborne data can be applied (Meijerink et al. 2005).

The effects of global climate change for the Carpathian basin forecast a warming trend, but no significant change in precipitation. However, significantly large and opposite trends are expected in different seasons. The seasonal precipitation amount is very likely to increase in winter (and to a smaller extent in spring), while it is expected to decrease in summer (Bartholy et al. 2007). The intensity of the precipitation will increase, because the same amount of precipitation will fall in a shorter period. This will likely increase the risk for inland excess water, since a larger amount of water needs to evaporate or find its way to channels and rivers gravitationally (Somlyódy et al. 2010).

\subsubsection{Land cover and vegetation}

The land cover is a factor which influences the formation of inland excess water, but also plays a role when the risk of inland excess water is determined. The land cover determines the type of activity that takes place on the surface, like for example agriculture or built-up area. If the area is an urban area, there will be more paved terrain and infiltration is limited. Furthermore, in these areas runoff will be faster, and probably via man-made systems. In rural areas, there are more possibilities for infiltration, but these depend on the agricultural system in use. Here for example, the type of ploughing, the use of fertilizers, and the use of heavy machinery all have influence on the soil (see $\S$ 2.3.3.) and the formation of inland excess water. The damage caused by the inundations is different depending on the land cover. In urban areas damages are normally higher than in rural areas (see $\S$ 2.5).

Vegetation can also be seen in two ways. It plays a role in the prevention of inland excess water, but it is also strongly influenced by the inundations. As mentioned in $\S 2.2$, most surplus water is disappearing via evapotranspiration. Via their leaf structure and the type of roots, the vegetation type determines the rate of transpiration. On the other hand, due to shading of the surface by vegetation the evaporation rate is negatively influenced. When crops are small, water is 
predominately lost by soil evaporation, but once crop are well-developed and completely cover the soil, transpiration becomes the main process (Allen et al. 1998).

Inland excess water can have a positive as well as a negative effect on vegetation. In wetlands, vegetation can develop unique patterns that cannot be found in drier regions. Strictly speaking, wetlands are inland excess water inundations, but they are normally not considered harmful, and as such are also to be treated differently than the inundation that have been discussed so far.

When the groundwater is rich in salts, inland excess water can cause salinisation, which is harmful to the vegetation. High groundwater levels may also saturate the soil, reducing the oxygen in the soil. This causes leaves to turn yellow due to lack of oxygen and insufficient nutrient intake (Kuti et al. 2006).

\subsubsection{Anthropogenic factors}

The anthropogenic factors involved in the development of inland excess water can be split into two groups. The first group is the human influence that causes floodings. An example of this is the construction of dikes along rivers during the $19^{\text {th }}$ century to protect the land against flooding. The dikes prevented the water to run downwards in a natural way into the main river. This problem was recognized and from 1886 it was required by law to provide possibilities for rain and melting water to run towards the river (Vámosi 2002). Still, similar problems occurred when the Dam of Tiszalök (North-East Hungary) was constructed in 1954 - blocking the gravitational transport of inland excess water - and a pumping station had to be installed to drain the water into the main river (Kovács \& Deme 2008). This is also a contemporary problem; the construction of roads and railroads can disturb the natural runoff of water towards the rivers and change the groundwater flow, causing inland excess water to occur in linear faults along infrastructures (Barta \& Szatmári 2010, Barta et al. 2011, Kozák 2011).

Within cities and villages, inland excess water occurs if there is no possibility for the water to infiltrate in the soil. Due to the high built-up density, and the reduced amount of green area, there are fewer and fewer places where water can be stored and/or infiltrate. Furthermore, on older buildings, gutters are sometimes missing. This results in water running down from the roofs in an uncontrolled manner, possibly towards local depressions, where it remains on the land. Gutters and drainpipes can direct the water towards channels.

Anthropogenic interference can also have large effects on the characteristics of the soil. Soil degradation due to intensive or inadequate agricultural practices may cause changes in the texture structure and chemical composition of the soil reducing its infiltration capacity (see $\S 2.3 .3$ ). The chemical and physical soil characteristics can be improved by soil amelioration. This increases the soil's drainage and makes it less vulnerable to inland excess water.

The privatization of collective agricultural land after the regime change in Hungary, in 1989, had its effects on the vulnerability to inland excess water (Rakonczai et al. 2011, Kozák 2011). After 
privatization, in many cases land was split up into smaller individually owned parcels. The large drainage systems that were collectively maintained earlier, where neglected and fell into decay, also channels covering larger areas were not properly maintained or sometimes destroyed.

A second type of anthropogenic factors influencing inland excess water are the hydrologic structures that are meant to reduce the effect of inundations. These structures consist of channels, pumping stations and reservoirs. If the capacity of the pumping station is lower than the required capacity to pump away the water that is brought to the pumping station via the network of inland excess water channels, inundations will occur sequentially in front of the pumping station (third type of inland excess water, see $\S 2.2$ Fig 2.4). Kozák (2006) found that in 2004, the total capacity of the pumping stations did not exceed their capacity in 1961.

Maintenance of channels is very important as well. If they are blocked by vegetation, soil or garbage the capacity is reduced, resulting in inland excess water faults just next to the channels.

A relatively new way of looking at the problem of inland excess water is to treat water as a valuable commodity. In many places, water shortage occurs during dry periods, while inland excess water occurs in wet periods. With careful water management programs, water can be stored during the wet periods, in the ground or in reservoirs, and can be used during dry periods (Kozák 2008, Somlyódy et al. 2010, Rakonczai et al. 2011). This also fits with the idea of returning to a more heterogenic land use (Bartos 2000), compared to the monoculture that has been in use since the emergence of the cooperatives during the socialist period. A more diverse land use allows for the combination of agricultural land, fallow land, forest, swamps, ponds etcetera in close proximity to each other. In this way, there is more space for the land to function as a buffer during wet periods.

\subsection{Inland excess water mapping}

The formation, size, duration and frequency of inland excess water are the result of a complex set of factors and their interrelations (see $\S 2.3$ ). There are two methods to estimate its spatial and temporal distribution: (1) To map the spatial and temporal distribution based on in situ or remotely sensed observations, and (2) to estimate the impact of a selection of principle factors and weighing those using experimentally derived coefficients.

\subsubsection{Mapping of actual inland excess water}

Systematic mapping of inland excess water has been executed since 1935 (Somlyódy et al. 2010). In earlier days, this could only be done by in situ observation of the inundations. More recently, remote sensing techniques have been used as well.

A. Traditional field measurements

Inland excess water maps have been created systematically by the Hungarian regional water directorates. These maps are created based on in situ observations and 1:10 000 and 1: 25000 
topographic base maps. From the topographic scale observations, 1: 50000 and 1: 100000 synergy maps are derived (Fig. 2.9).

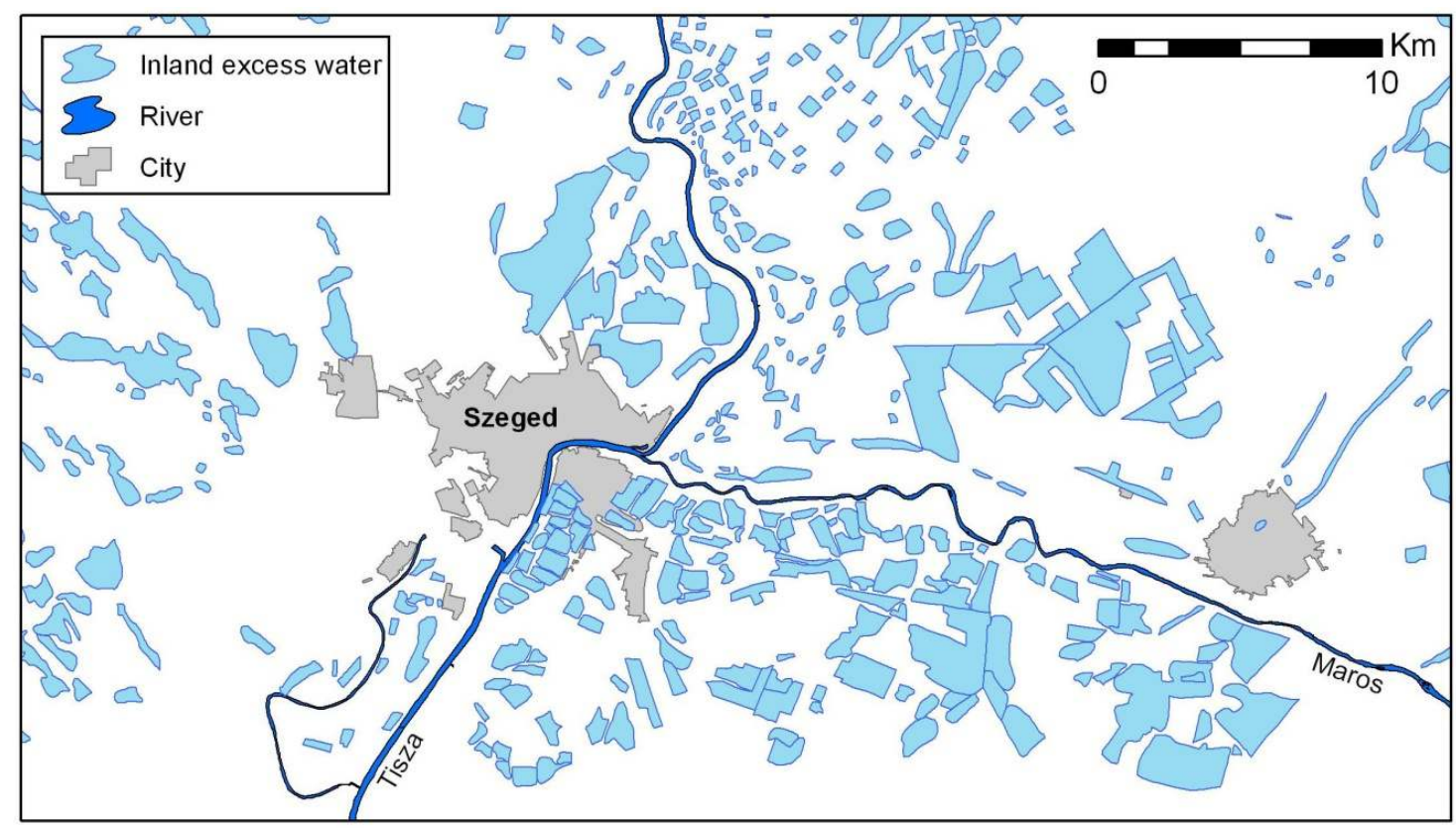

Figure 2.9 Inland excess water map showing in situ observations of 2000. Source data: ATIKÖVIZIG

This type of observation is time-consuming and error-prone due to differences in observation methods and quality. An inland excess water patch does not have a clear boundary, because the soil surrounding it is normally saturated with water. Due to its swampy nature, it is very difficult to measure every inland excess water patch individually (Licskó B, 2009). If the observation maps are combined temporarily, a composite occurrences map is created (Fig. 2.10).

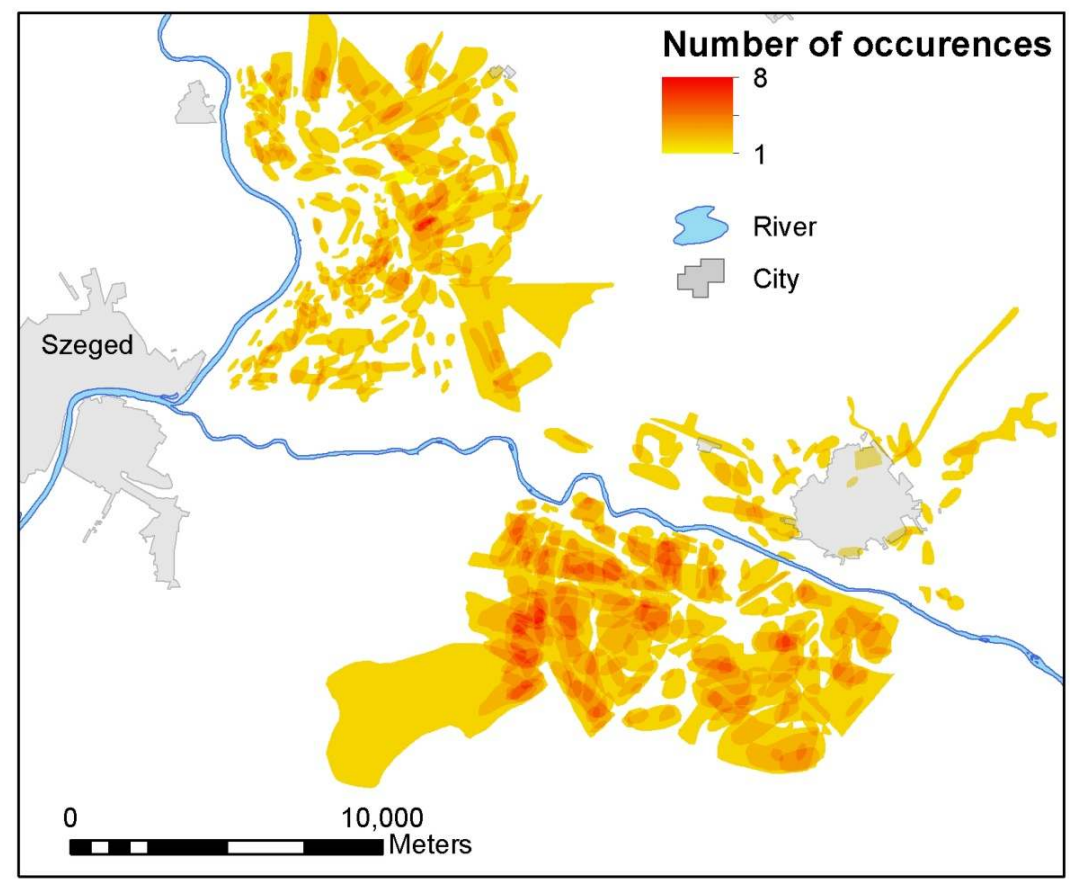

Figure 2.10 Composite map showing the number of occurrences of inland excess water between 1960 and 2001. 
These composite maps are often used in inland excess water studies, as evidence of the spatial distribution of inland excess water occurrences. It is impossible to quantify the quality of the base data for these maps, because they are created in different periods, by different people, using different methods. Therefore they should be used with care.

To evaluate the applicability of the in situ observations as accurate ground truth for the neural network classification, they were statistically compared with a map with local depressions calculated from a LIDAR derived digital elevation model (see also $§$ 4.2.2.).

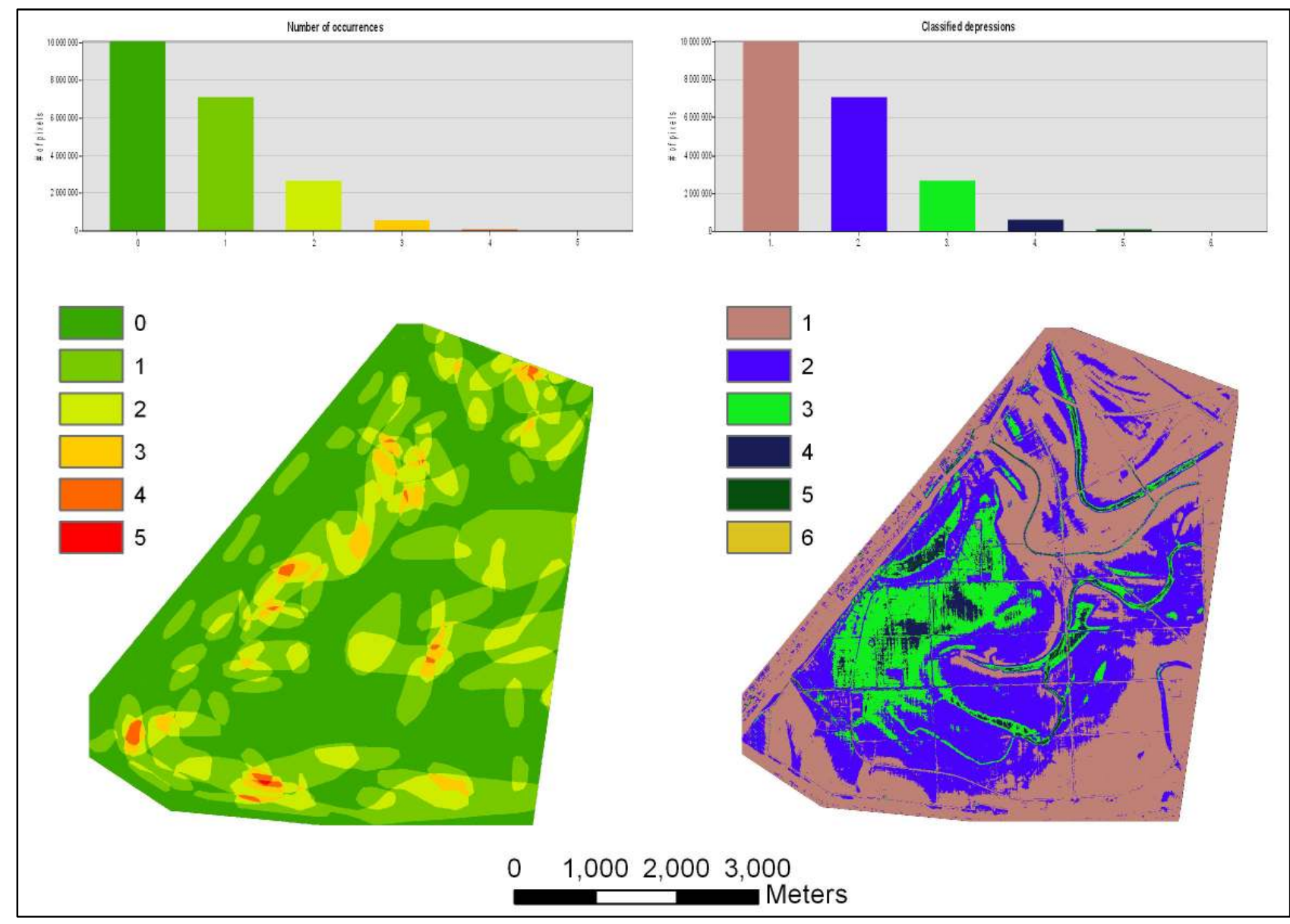

Figure 2.11 Statistical comparison between measured inland excess water occurrences (left) and local depressions (right)

Figure 2.11 left shows the number of years, ranging from never to 5 times, that inland excess water occurred in a $20 \mathrm{~km}^{2}$ large study area between 1960 and 2011 . The histogram of the map is given above it. The map with the local depressions was classified using the distribution of the classes of the occurrences. In other words, the depths of the local depressions were classified in such a way, that each class contained the same amount of pixels. For example, the number of pixels where most inland excess water occurred (5 times) is equal to the number of pixels of the deepest local depression class. The result is shown in figure 2.11 right.

From the two maps, a cross table was calculated. If a relation between the number of occurrences of inland excess water and the depths of the local depressions exists, it should be visible in this cross 
table (table 2.2). Obviously, there is no relationship between these two data sets; the areas where most often inland excess water occurs (4-5 times), correspond with the least deep depressions (class 1 and 2). Areas with few inland excess water inundations are found in all depression classes.

Table 2.2 Cross table with the occurrences class in the columns and the classified depressions in the rows. The cells give the number of pixels

\begin{tabular}{|c|c|c|c|c|c|c|c|c|}
\hline & & 0 & 1 & 2 & 3 & 4 & 5 & $\begin{array}{r}\text { Number of } \\
\text { Occurrences }\end{array}$ \\
\hline shallow & 1 & 4804177 & 3616976 & 1262248 & 303544 & 52069 & 112 & 10039125 \\
\hline 4 & 2 & 3596326 & 2323038 & 912891 & 202251 & 54839 & 3682 & 7093027 \\
\hline & 3 & 1302509 & 886859 & 412623 & 71379 & 3257 & 0 & 2676626 \\
\hline & 4 & 303678 & 232745 & 81919 & 4052 & 70 & 0 & 622464 \\
\hline$\downarrow$ & 5 & 65863 & 36495 & 10313 & 4750 & 0 & 0 & 117421 \\
\hline deep & 6 & 1692 & 1054 & 351 & 152 & 0 & 0 & 3250 \\
\hline Depressions & & 10074245 & 7097167 & 2680345 & 586127 & 110235 & 3794 & 20551913 \\
\hline
\end{tabular}

The field observations are also combined to create an overview map for the whole country showing four qualitative levels of inland excess water protection preparedness, ranging from first degree to exceptional for every inland excess water protection section (Fig. 2.12).

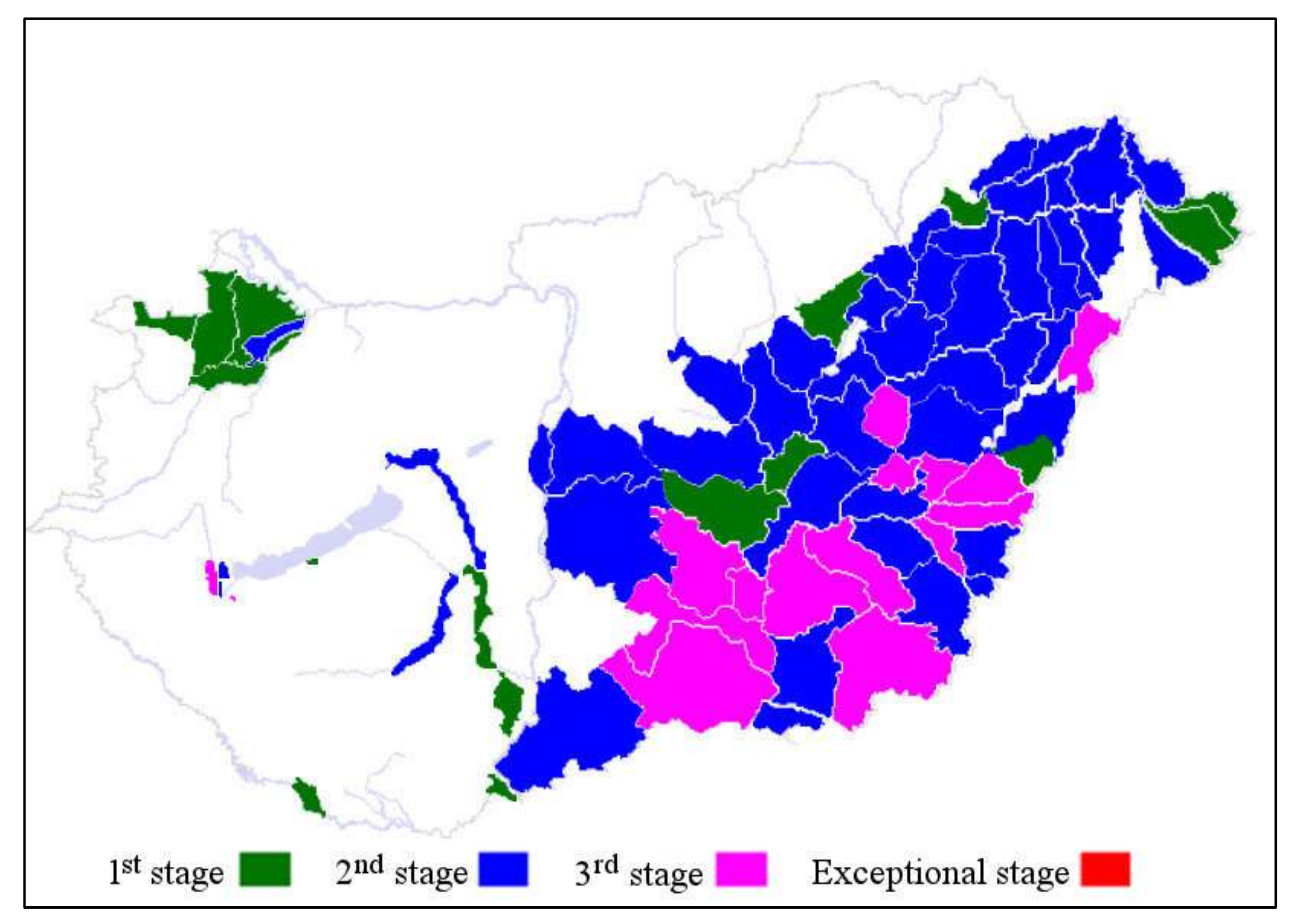

Figure 2.12 Inland excess water protection preparedness on 9 December 2010 (source: Vízügy)

During inland excess water periods the National Directorate for Environment, Nature and Water (VÍZÜGY) refreshes and publishes this map on a daily basis. Although, it does not provide the precise amount of hectares covered by inland excess water, it does show the tendency of the severity of the inundations. 


\section{B. Remote sensing based measurements}

With the appearance of publicly available remote sensing data, like aerial and spaceborne imagery and the development of image processing techniques, in situ observations were complemented and inland excess water could and can be identified and classified in a more efficient and effective way (Rakonczai et al. 2003). Efficient mapping of inland excess water over large areas is only possible using these remote sensing techniques (Licskó B, 2009).

Many different remote sensing data and techniques were used to identify inundations. For example, Csekő (2003) used radar data to monitor inland excess water, a combination of radar and optical sensors was used by Csornai et al. (2000), Rakonczai et al. (2001) compared Landsat based classification of inland excess water with in situ measurements, both Licskó (2009) and Szatmári et al. (2011b) used aerial data to identify inland excess water floodings and Mucsi \& Henits (2011) used sub-pixel based classification on a Landsat time series to identify inundations.

A disadvantage of most remote sensing acquisition techniques is that they are dependent on good weather, and inland excess water often occurs during periods with lots of precipitation. Active sensors do not have this problem, but they normally have lower resolutions and are more difficult to interpret and process. Also, the dynamic nature of the floodings causes problems. Especially spaceborne remote sensors have a limited revisiting time, which may result in inaccurate measurements of inland excess water because the flooded area may have reduced in size or disappeared already by the time the satellite passes over the area. Airborne sensors can be used to overcome this problem. But airborne data acquisition over a large area is costly, so for financial reasons it is often not feasible to acquire data with a high temporal frequency. Vegetation may further reduce the usability of remote sensing data, since it may obstruct the sensor to acquire imagery of inundations.

\subsubsection{Vulnerability mapping}

Vulnerability mapping of inland excess water is traditionally executed by selecting a limited set of factors causing the floodings and by weighing those using coefficients that are derived experimentally. The weights of the coefficients are adapted to match earlier observations or are based on expert knowledge. Many authors have calculated inland excess water vulnerability maps based on such a limited set of factors like relief, soil, groundwater and precipitation (Bozán et al. 2009, Pálfai 2003, Pásztor et al. 2006).

Pálfai and others developed the so-called Complex Inland Excess Water Vulnerability Index in several steps (Bozán et al. 2009, Pálfai 2003, Pálfai 2004a, Körösparti et al. 2009). Their final index is based on 6 main factors namely hydrometeorology, relief, soil, geology, groundwater and land use. The index is described here in detail as an example of inland excess water vulnerability mapping. The expression of the index is: 
Index $=1,976-0,221 *$ SOIL $-0,002 *$ GEOLOGY $-0,076 *$ LANDUSE $+0,022 *$ RELIEF $-0,151 *$ GROUNDWATER

The weight of each factor is derived using a regression model that is applied on actual occurrences of inland excess water. The weight factors vary geographically. The different factors themselves are also composed of multiple parameters:

\section{a. Hydrometeorology}

First the hydrometeorological factor is calculated. This factor is a threshold which is not used in the expression itself. It just determines if the index can be applied or not. Only if the HUMI value is not part of the $10 \%$ lowest values of all HUMI values, the inland excess water index is valid and can be calculated. Its formula is the following:

$H U M I=\left(\frac{p^{*}}{P E T}\right)^{0,5}$

where $p^{*}$ is the weighted precipitation according to table 2.3.

Table 2.3 Precipitation weights based on the months of the year

\begin{tabular}{|l|l|l|l|l|l|l|l|l|l|l|l|l|}
\hline Month & X & XI & XII & I & II & III & IV & V & VI & VII & VIII & IX \\
\hline Weight & 1,0 & 1,5 & 2,0 & 2,0 & 2,0 & 1,5 & 1,0 & 0,75 & 0,5 & 0,5 & 0,5 & 0,75 \\
\hline
\end{tabular}

PET is the potential evapotranspiration and is based on the monthly mean temperature in the

winter and summer.

\section{b. Soil}

The SOIL factor is based on the estimated hydraulic conductivity in $\mathrm{cm} /$ hour (Table 2.1)

\section{c. Geology}

The GEOLOGY factor is based on the depth and thickness of the impermeable layer in the soil and is given in table 2.4 where the vulnerability varies between 0,1 (most vulnerable) and 5 (least vulnerable).

Table 2.4 Values for the GEOLOGY factor based on thickness and depth of the impermeable layer

\begin{tabular}{|l|c|c|c|c|c|}
\hline \multirow{2}{*}{ Thickness } & \multicolumn{5}{|c|}{ Depth of impermeable layer } \\
\cline { 2 - 6 } & At surface & $<2 \mathrm{~m}$ & $2-4$ & $4-10$ & $>10 \mathrm{~m}$ \\
\hline$<1 \mathrm{~m}$ & 0,2 & 1,8 & 3,6 & 4,8 & 5 \\
\hline $1-2 \mathrm{~m}$ & 0,1 & 1,5 & 2,7 & 4,2 & 5 \\
\hline $2-4 \mathrm{~m}$ & 0,1 & 0,9 & 1,8 & 3,4 & 5 \\
\hline$>4 \mathrm{~m}$ & 0,1 & 0,3 & 1,1 & 3,0 & 5 \\
\hline
\end{tabular}

\section{d. Land use}

Every land use category on the CORINE land use map (CLC50, Büttner et al. 2004) receives a value that expresses the vulnerability to inland excess water. These values are stored as the LANDUSE factor 


\section{e. Relief}

RELIEF $=($ elevation above sealevel $/ 75) *$ relief energy

The relief energy is defined as the difference between the minimum and maximum height within one $\mathrm{km}^{2}$.

\section{f. Groundwater}

The GROUNDWATER factor is the average groundwater depth calculated over the maximum groundwater levels during four 10-year intervals in the last 40 years.

The regression analysis using an inland excess water occurrences map (Fig. 2.10) as dependent variable gives the weights for every factor. Figure 2.13 shows a result of calculations as described above for the Csongrád province. The low values indicate a small change for inland excess water, while the highest values indicate a large risk of inland excess water.

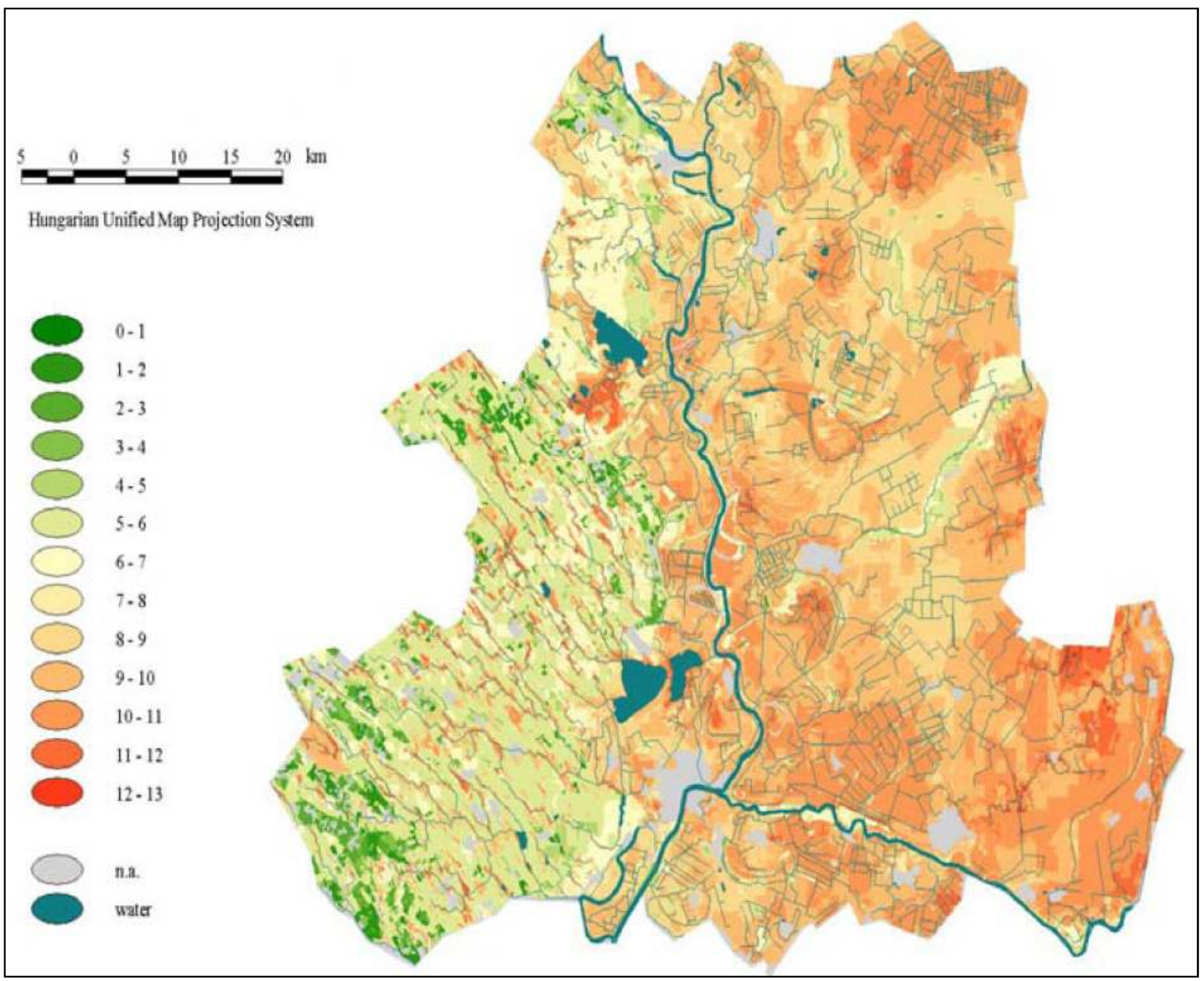

Figure 2.13 Complex Inland Excess Water Vulnerability Index for Csongrád province, Hungary (Bozán et al. 2009) 
Another example of a vulnerability map is the well-known 1:500 000 inland excess water vulnerability map created by Pálfai, in which four classes are identified based on the relative frequency of inland excess water occurrences (Table 2.5), adapted by elevation, soil, geological and groundwater data (Pálfai 2003).

Table 2.5 Pálfai inland excess water vulnerability categories

\begin{tabular}{|c|c|c|}
\hline Vulnerability category & Relative frequency & Qualitative description \\
\hline 1 & $<0,05$ & No or low vulnerability \\
\hline 2 & $0,05-0,10$ & Minor vulnerability \\
\hline 3 & $0,11-0,20$ & Average vulnerability \\
\hline 4 & $>0,20$ & High vulnerability \\
\hline
\end{tabular}

The maps were created in analogue form in 2002 and digitized by the Central bureau of Water and Environment (Vízügyi és Környezetvédelmi Központi Igazgatóság) in 2008 (Fig. 2.14)

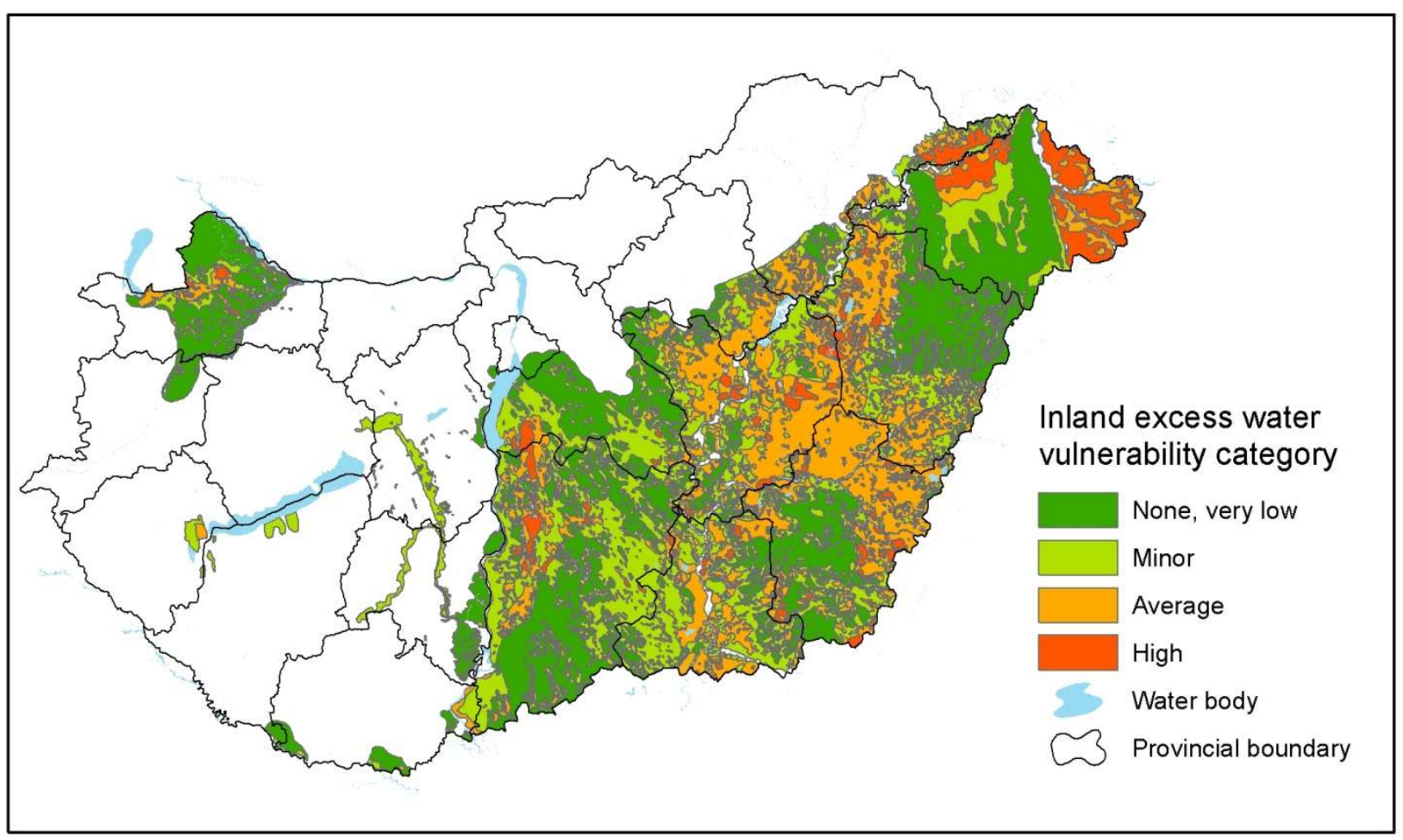

Figure 2.14 Inland excess water vulnerability map by Pálfai (Pálfai 2003)

\subsection{Damage caused by inland excess water}

Since inland excess water is a phenomenon that occurs irregularly (Fig. 1.2), the damage it causes also fluctuates. The financial damage to just the agricultural sector of the severe inland excess water period of 2010-2011 exceeded 500 million Euros according to the Secretary of State for Agriculture (Agrárszektor 2011), but there are also years without almost any financial damage. Another aspect of inland excess water is its regional variation; since the inundations are usually caused by excessive rainfall, there are often also areas where this extra rainfall causes increased yields. In this 
way, the negative effects on the agricultural output in one geographical region are sometimes smaller than the positive effects of the increased agricultural production in another region.

Foremost, inland excess water causes damage to the agricultural sector. This damage can be split in two types (Thyll \& Bíró 1999). The first type of damage is a decrease in quantity and quality of agricultural goods, which results in lower income from agricultural production in the short term. Furthermore, a farmer has extra cost because it is more difficult to cultivate the land and to harvest, and because of structures that need to be built to mitigate the damages caused by the inundations, like building temporary dikes and channels, or pumping away water. This direct damage continues as long as the inland excess water period remains.

The second type of damage causes long term harm to the agricultural sector due to damage of the soil structure and reduced fertility of the soil (also see $\S 2.3 .3$ ). These costs are much more difficult to estimate since they are spread over a longer period.

Apart from the economic impact of inland excess water to the agricultural sector and the costs of prevention, protection and remediation, there are also other consequences. Environmental problems occur due to the inundations, because the water spreads pollutants, like pesticides and fertilizers. In some regions, like at Algyö oilfield, which is part of the study area of this research, oil wells are situated in the flooded terrain (Mucsi 2001). Minor oil spills can easily pollute a larger area if inland excess water transports the oil to other places. When the water covers the land for longer periods, it can also cause changes in the natural vegetation.

When inland excess water occurs near farms or within villages the social impact can be big. Houses can become (temporarily) uninhabitable (Fig. 2.15) and roads inaccessible (Fig. 2.8). Spatial impact might occur because of land use changes; agricultural land might be returned to wetland if continuous inundations occur, or the land might be cultivated with more water resistant crops.

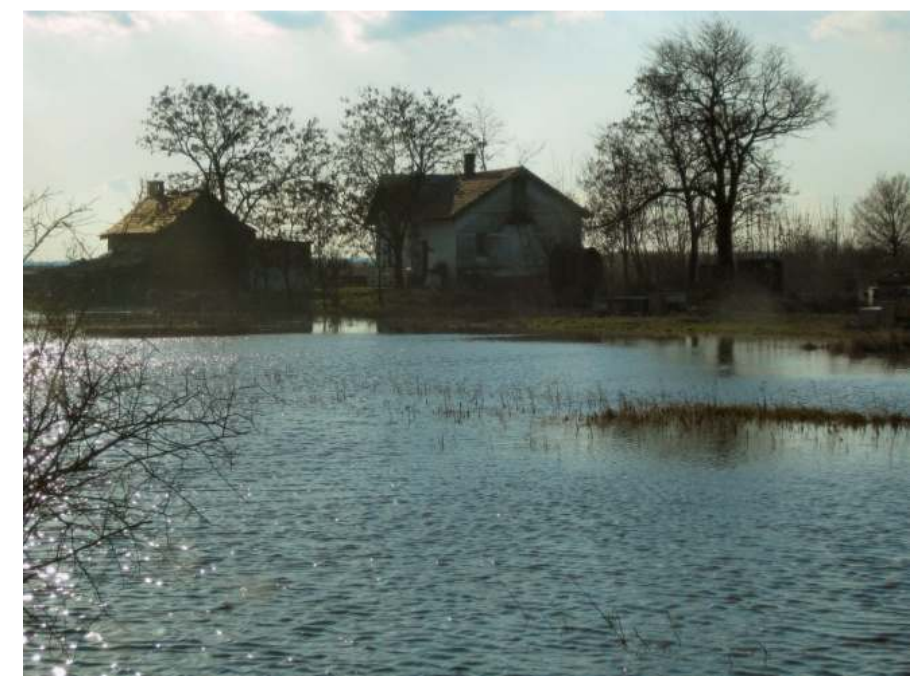

Figure 2.15 A farm near Szentes, Hungary surrounded by inland excess water (source: van Leeuwen) 


\subsection{Prevention, protection and remediation}

Prevention against and mitigation of inland excess water can be executed in many ways. Technical/engineering solutions consist of building open channel systems or field drainage systems combined with pumping stations (Fig. 2.16).

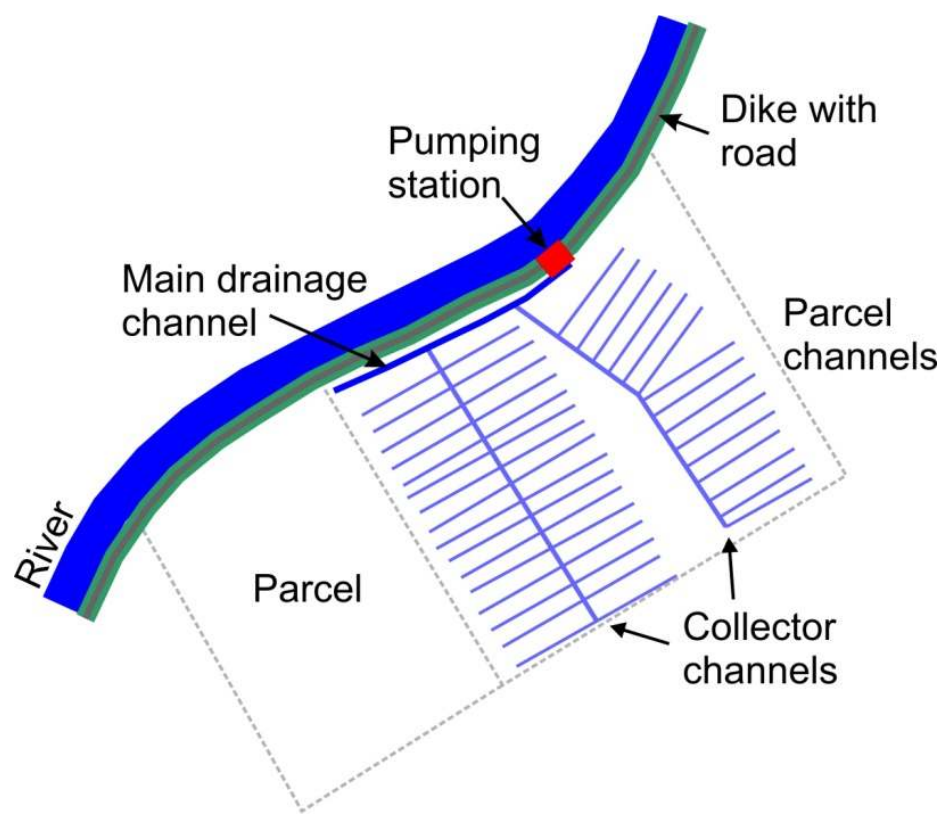

Figure 2.16 Schema of a region drained using underground drains and open drainage channels (after Ritzema 1994)

Since the initial costs to build underground drainage systems are very high, and the costs of maintenance are also considerably high, in many regions this type of prevention is not feasible. In these cases, the economic balance between the costs of the drainage system and the costs due to inland excess water is unfavourable. For this reason, in many regions, open channels systems are the only engineering solution to prevent inland excess water, although these also need considerable maintenance.

Just building extra channels is not solving the inland excess problem. Kozák (2006) found that there is no relationship between the total length of drainage channels and the area covered by inland excess water. During the last half century, the capacity of the channel system doubled but the amount of land covered with inland excess water remained very fluctuating (Fig. 2.17.).

Channels can also result in shifting the problem of inland excess water from its original location, where there are bad physical conditions, toward the pumping station, where there is not enough capacity. In this case, the queuing up type of inland excess water happens (see $\S 2.2$ ). 


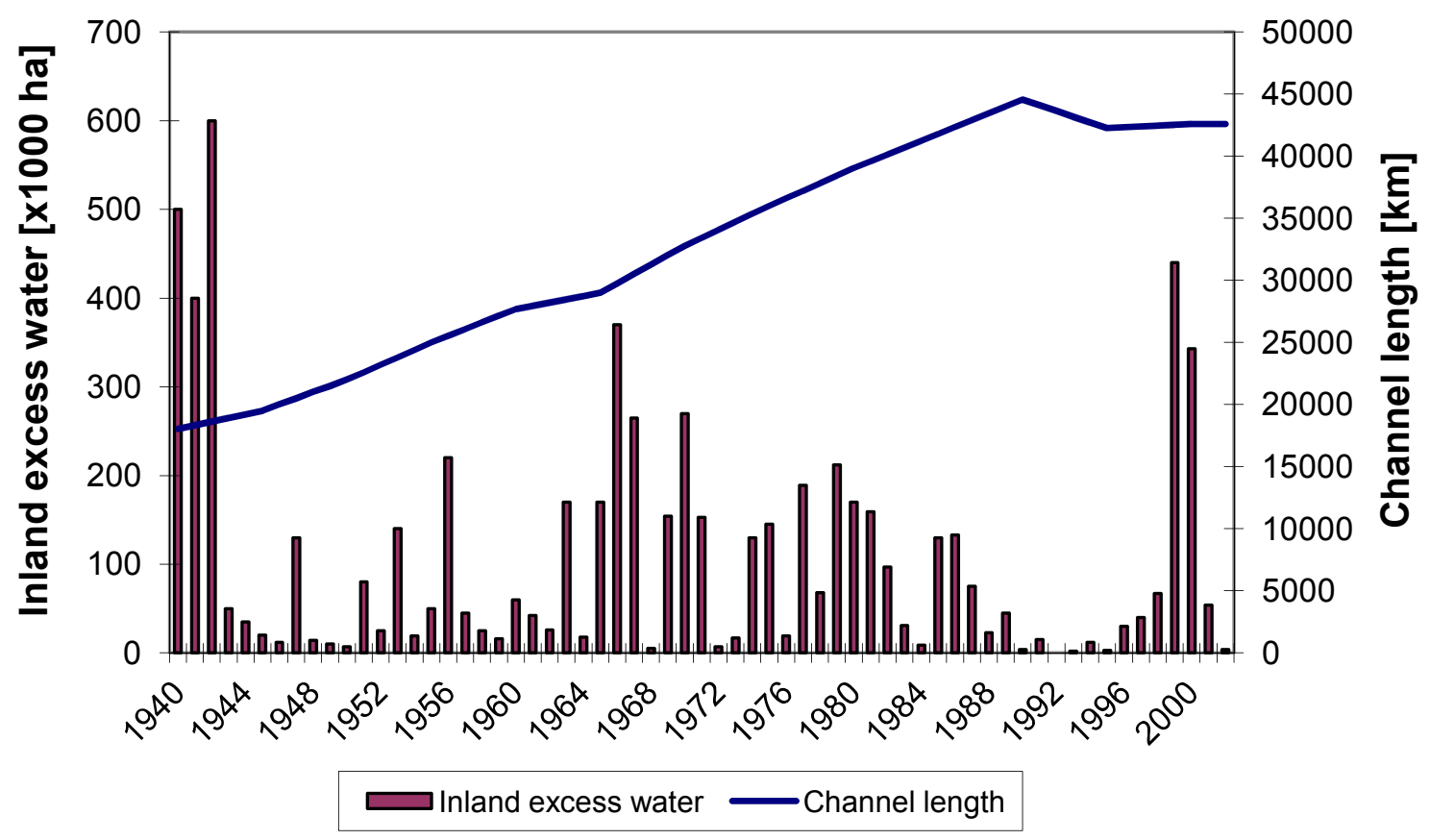

Figure 2.17 Relationship between drainage channel length and inland excess water (Kozák 2006)

Other solutions consist of biological drainage, where increased vegetation surfaces, like forests result in increased transpiration to reduce the amount of surface water. The construction of reservoirs also helps storing surplus water, and has the advantage that the water can be used in drier periods to mitigate drought. 


\section{Artificial neural networks - theoretical background}

\subsection{Background of artificial neural networks}

The modern view on neural networks began in the 1940s with the work of McCulloch and Pitts (1943), who showed that networks of artificial neurons could, in principle, compute any arithmetic or logical function. Their work is often acknowledged as the origin of the neural network field (Hagan et al. 1996). After a booming period during the 1950s and 1960s, interest in artificial neural networks reduced due to limitations of the then available networks and limited scientific progress. Except for a small group of scientists (e.g. Kohonen (see $\S$ 3.3.2.)), most researchers devoted their attention to other fields of science. Renewed interest came when Paul Werbos wrote his PhD dissertation about the development of the backpropagation algorithm (Hagan et al. 1996).

Since then, artificial neural networks have been developed in many scientific fields and used for numerous applications. This chapter will discuss their theoretical background and their use in geography and associated fields.

Artificial neural networks are computational models that mimic the functioning of the human brain. They are computational mechanisms that are able to acquire, represent, and compute a mapping from one multivariate space of information to another, given a set of data representing that mapping (Atkinson \& Tatnall, 1997). Other names for artificial neural networks are computational neural networks (e.g. Openshaw 2000) or parallel distributed processors (McClelland \& Rumelhart 1986, McClelland 2011, Rumelhart \& McClelland 1986). In this dissertation, the term artificial neural network or $A N N$ will be used.

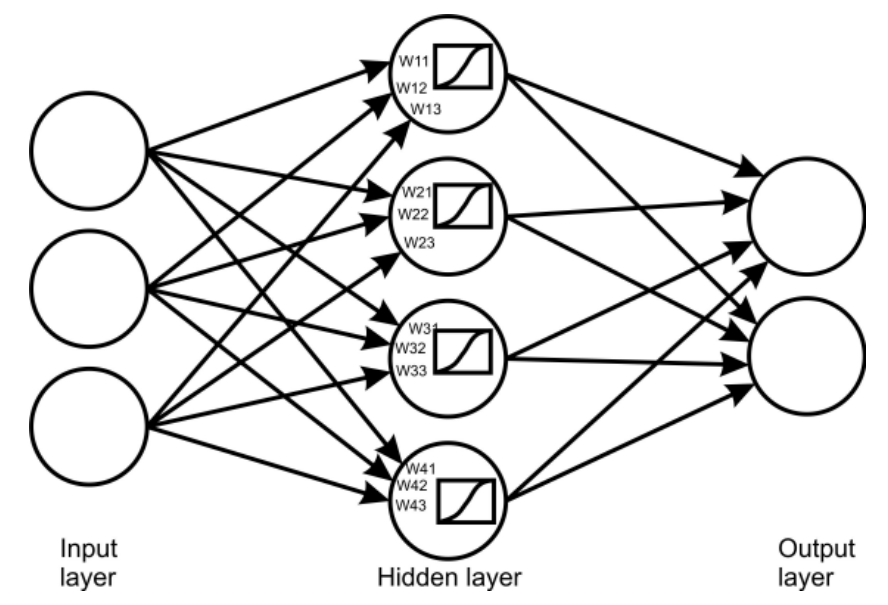

Figure 3.1 Basic artificial neural network

Artificial neural networks do not approach the complexity of the brain. There are, however, several key similarities between biological and artificial neural networks. First, the building blocks of both networks are simple computational devices (although artificial neurons are much simpler than biological neurons) that are highly interconnected. Second, the connections between neurons determine the function of the network (Hagan et al. 1996). Third, information is not stored in any 
single location, but rather in a parallel, distributed form. Fourth, mechanisms exist in which new information can be 'learned' through changes that potentially affect large portions of the network (Agarwal \& Skupin 2008). Schematically, a basic artificial neural network can be depicted as a structure consisting of multiple layers of interconnected nodes as shown in figure 3.1 (Dawson \& Wilby 2001, Gurney 1997, Hagan et al. 1996).

The application of ANNs consists of two phases. The first phase is called the training phase. During this phase the ANN is fed with an input and an associate output data set. The training is an iterative process that aims to adapt the network internally in such a way that the calculated results from the network are as close as possible to the expected results. Many different types of training algorithms exist (see $\S 3.5$ ). The result of the training phase is a trained network. This network is used in the simulation phase to generate new output results based on new input data. The new input data is different from the training input data but covers the same problem domain.

\subsection{Basic architecture of artificial neural networks}

The following paragraphs describe the general functioning of artificial neural networks. This description is based on the detailed descriptions of neural network architectures in particularly Hagan et al. 1996. Also Retter 2006, Freeman \& Skapura 1991, Demuth et al. 2010, McClelland 2011, Zurada, 1992 and Neural networks and their applications by Clothiaux and Bachmann in Neural nets: Applications in Geography (Hewitson \& Crane 1994) were used for this purpose.

The individual neurons (which are also called nodes, units, or processing elements (PEs)) can be modelled as in figure 3.2, where in the left picture, one input scalar $p$ is multiplied by weight $w$, and a bias $b$ is multiplied with the other input 1. Terms $w p$ and $b$ are summed to form output $n$, which is called the net output. The type of connection is reflected by the sign of the weight. Excitatory connections have positive weights, while inhibitory connections have negative weights. Biases are used to modify the net output $n$ to prevent it from becoming 0 in case that the input $p$ or weight $w$ of a neuron is equal to 0 . The net output $n$ goes into a so-called activation function $f$ where it produces output $a$. Activation functions determine the rate of transfer to the next neuron, and are discussed in more detail in $\S 3.4$. The neuron output $a$ is computed as $a=f(w p+b)$. In reality, neurons usually have multiple inputs, as it is shown in the right picture. In case of $\mathrm{R}$ inputs, each single input $p_{1}, p_{2}$, $\ldots, p_{R}$ is multiplied by its corresponding weight $w_{1,1}, w_{1,2}, \ldots, w_{1, R}$, where the first index is the neuron destination for that weight, and the second is the source. Weights $w_{1,1}, w_{1,2}, \ldots, w_{1, R}$ form the weight vector $\mathbf{w}$, and the inputs form vector $\mathbf{p}$. The net input is then $n=w_{1,1} p_{1}+w_{1,2} p_{2}+\ldots+w_{1, \mathrm{R}} p_{\mathrm{R}}+$ $b$ or $n=\mathbf{w} \cdot \mathbf{p}+b$. The resulting neural output becomes then $a=f(\mathbf{w} \cdot \mathbf{p}+b)$. 
Inputs General neuron

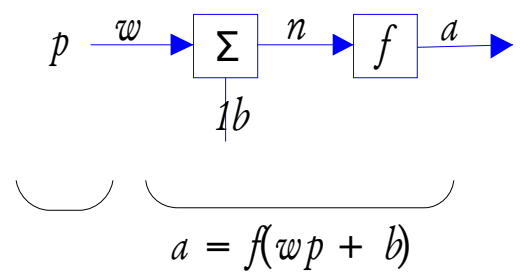

Inputs General neuron

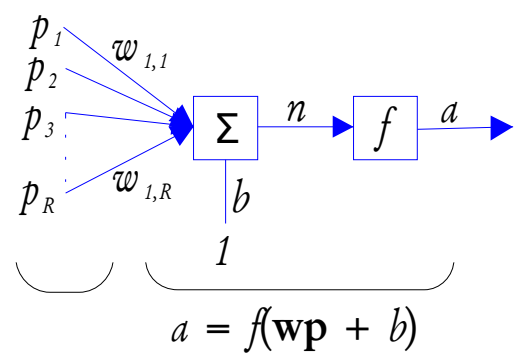

Figure 3.2 Schematic model of an individual neuron with a single input (left) and with multiple input neurons (right) (Hagan et al. 1996)

Normally, single neurons are not sufficient to solve real world problems, but layers of neurons operating in parallel are required. Combining several layers of neurons result in neural networks. The simplest artificial neural networks consist of one input layer, a hidden layer and an output layer. The input and output layers are known to a user, while the hidden layer is a set of neurons without known content. The hidden layer does not have any connection to the outside world.

Following the same graphical notation as in figure 3.2, a neural network with two layers of $S$ neurons can graphically be presented as figure 3.3.

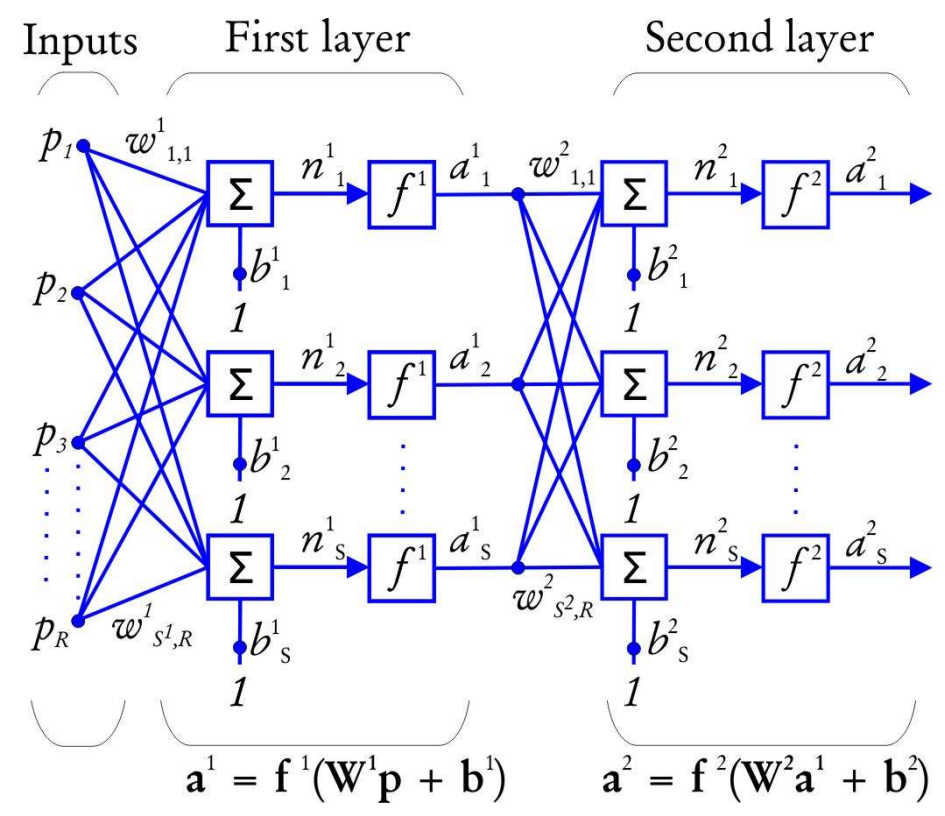

Figure 3.3 Schematic model of an artificial neural network with two layers of $S^{i}$ neurons (Modified after Hagan et al. 1996)

The output of the first layer is $\mathbf{a}^{1}=\mathbf{f}^{1}\left(\mathbf{W}^{1} \mathbf{p}+\mathbf{b}^{1}\right)$. Now $\mathbf{a}^{\mathbf{1}}$ and $\mathbf{b}^{1}$ are vectors instead of scalars since they vary for every neuron in the layer. 
The activation function of the first layer is denoted by $\mathbf{f}^{1}, \mathbf{W}^{1}$ is a matrix containing the weights for every neuron and input $P_{1} \ldots P_{\mathrm{R}}$ in the first layer:

$$
\mathbf{W}^{1}=\left[\begin{array}{cccc}
w_{1,1}^{1} & w_{1,2}^{1} & \cdots & w_{1, R}^{1} \\
w_{2,1}^{1} & w_{2,2}^{1} & \cdots & w_{2, R}^{1} \\
\vdots & \vdots & \vdots \\
w_{S, 1}^{1} & w_{S, 2}^{1} & \cdots & w_{S, R}^{1}
\end{array}\right]
$$

Similarly, $\mathbf{a}^{2}=\mathbf{f}^{2}\left(\mathbf{W}^{1} \mathbf{a}^{1}+\mathbf{b}^{2}\right)$ where the inputs are now the outputs of the first layer. The second layer has its own activation function and weight matrix containing the weights for every neuron. So, the output of this network is given by:

$$
\mathbf{a}^{2}=\mathbf{f}^{2}\left(\mathbf{W}^{2} \mathbf{f}^{1}\left(\mathbf{W}^{1} \mathbf{p}+\mathbf{b}^{1}\right)+\mathbf{b}^{2}\right)
$$

Every layer has its own activation function, weight matrix and biases. This neural network has one output layer (layer 2) and one so-called hidden layer (layer 1). Note that in this example every neuron in one layer is connected to every neuron in another layer. Although this is common, many architectures exist that rely on different interconnection schemes (Freeman \& Skapura 1992). The complexity and capability of a network depends on the amount of hidden layers and the number of neurons per layer. A single layer network is capable of classifying linearly separable data (Atkinson $\&$ Tatnall 1997), while a two-layer network with a log-sigmoid activation function (see $\S 3.4$ ) in the first layer and a linear activation function in the second layer (as used in chapter 5) can be trained to approximate most functions arbitrarily well (Hagan et al. 1996).

The decision of what neural network architecture to use is one of the basic problems in the field of neural network research (Hagan et al. 1996, Rumelhart et al. 1994). The amount of neurons in the input layer is determined by the application in which the network is used; if the number of relevant factors is $\mathrm{X}$, then $\mathrm{X}$ input layers are needed. The same is true for the number of output neurons; if $\mathrm{Y}$ outputs are expected from the network, then Y neurons are required in the output layer. It is more difficult to determine the number of hidden layers and the number of neurons in those layers.

The amount of hidden layers and the amount of neurons in the hidden layers determine the learning capability of the network. If there are too few neurons in the hidden layers, the network may be unable to describe the underlying function of a problem because it has insufficient parameters to map all samples in the training data. On the other hand, if there are too many neurons, the network has too many free parameters and may over-fit the data, losing the ability to generalize (see $\S 3.5$ ). In addition, an excessive number of hidden neurons can retard the training process to such an extent that it takes an inordinate length of time for a network to learn (Dawson \& Wilby 2001). According to Kolmogorov`s theorem, with $2 n+1$ hidden neurons (with $n$ being the number of input neurons) any continuous function can be represented exactly (Bishop 1995). 


\subsection{Types of artificial neural networks}

Since the first experiments in the 1940s and 1950s, many different artificial neural networks have been developed. A selection of the most common ANNs is presented in this paragraph. Many handbooks exist that provide a larger list of neural networks, and describe them in more detailed. Some of these are: Gurney 1997, Freeman \& Skapura 1991, Hagan et al. 1996 and Zurada 1992.

There are several possibilities to distinguish different types of ANNs. One way is to make a distinction between networks that are feed forward in nature, where the data flow is strictly happening in a way, that no feedback is present from the output to the input neurons, and those networks that are recurrent in nature. These networks do incorporate feedback connections between (some of the) output and input neurons. Obviously, time and time delay play important roles in these networks. Examples of feed forward neural networks are Multi Layer Perceptron and Adalin, while recurrent networks are for example Kohonen self-organising maps and Hopfield nets.

Another way to group ANNs is based on their training properties. This divides ANNs in supervised and unsupervised artificial neural networks. A supervised network is used for classification of a set of input variables into a known set of output variables. When the network is trained, the expected output is defined. On the contrary, an unsupervised neural network is used for clustering of input data based on similar characteristics, without a fixed output target. The aim of unsupervised neural network modelling is to find patterns, while the aim of supervised neural network modelling is to model the relationship between the input and output data.

\subsubsection{Supervised networks}

The purpose of a supervised ANN is to build a model of the data generating process, so that the network can generalize and predict outputs from input that it has not previously seen (Pradhan et al. 2010a). Commonly used supervised ANNs are:

\section{- Multi Layer Perceptron}

One of the most popular artificial neural models used in pattern classification, prediction and regression tasks is the multilayer perceptron (MLP) (Atkinson \& Tatnall 1997, Demuth et al. 2010, Pradhan et al. 2010a). The network is based on Rosenblatt's single node experiment in 1957 (Rosenblatt 1958). He developed a 'machine' that could learn and store information, and was capable of classifying linearly separable data and performing linear functions (Pijanowski et al. 2002). An MLP is the feed forward multilayer version of Rosenblatt's experiment where a signal propagates in a forward manner from one layer to the next layer and is modified by the associated weights of each connection (Pradhan et al. 2010a). This means that there is neither direct, nor indirect influence from a given neuran to its own inputs (Rumelhart et al. 1994). The network has at least one hidden layer, where usually a sigmoid function (see $\S 3.4$ ) is applied. MLPs can identify nonlinear relationships (Atkinson \& Tatnall 1997, Zurada 1992). They are often combined with a backpropagation learning algorithm (see $\S 3.5$ ). The earlier exemplary description of the neural 
network in $\S 3.2$ is a MLP. Throughout this research, an MLP was used to identify inland excess water inundations (see chapter 5).

- Feed forward radial basis function network

The structure of a radial basis function (RBF) network is identical to a MLP, but it uses a network of Gaussian basis functions in the hidden layer and linear activation functions in the output layer. The Gaussian basis activation functions are described in $\S 3.4$. Training of a RBF involves two stages. First, the distance between the input data and the center vectors is calculated (Bishop 1995). These center vectors are the centers of cluster derived from the input data (Jayawardena et al. 1997). In the second stage, the weights linking the hidden and the output layer are calculated directly using matrix inversion and multiplication. This direct calculation of the weights makes the training of a RBF much faster than of an MLP (Dawson \& Wilby 2001, Gurney 1997).

- Adaline network

An Adaline is a single layer neural network with multiple nodes where each node accepts multiple inputs and generates one output. It was developed by Widrow and Hoff at Stanford University in 1960. Originally Adaline was an acronym of ADAptive Linear NEuron, but later this became ADAptive LINear Element. It is almost identical in structure to the general neuron as in figure 3.2. The difference between them is that in the learning phase of the Adaline net, the weights are adjusted according to the weighted sum of the inputs. In general, the weights are adjusted based on the outputs of the activation functions (Freeman \& Skapura 1991). A Madaline (Many Adaline) network is created by combining a number of Adalines into a two-layer neural network. A Madaline network can be applied to pattern recognition problems (Widrow \& Lehr 1995).

\subsubsection{Unsupervised networks}

Unsupervised networks try to discover any relationships of interest that may exist in the input data. These networks can discover patterns, features, regularities, or categories without a teacher. In unsupervised learning, the input vectors do not correspond to classes known a priori. Output nodes compete for the input vectors on the basis of certain similarity functions and the weights of winning nodes are adjusted according to the weights of respective input nodes (Agarwal \& Skupin 2008). Networks trained in this way will not only react to values of inputs but also to their statistical parameters. Unsupervised learning can only be implemented with redundant input data. Redundancy provides knowledge about statistical properties of input patterns. (Zurada 1992).

- Kohonen Self Organising Maps

The most widespread unsupervised ANNs are self-organizing maps (SOM, Kohonen Map). They have been developed by Kohonen (Kohonen 2001). They classify n-dimensional input samples $(\mathrm{n}>2)$, and add them to the elements of a lower-dimensional output layer. Similar samples are associated with neighbouring elements of the output layer, i.e. apart from the distribution of the 
samples in the input space, it also learns the topology between them. The SOM performs data clustering and dimension reduction at the same time (Agarwal \& Skupin 2008). SOMs are made up of two layers. The input and output (or Kohonen) layers that are connected to each other through all of their neurons (Fig. 3.4). Data is fed into the input layer, which has the same number of neurons as the number of input variables. Classification takes place in the Kohonen layer, where the number of classes created during the training process is equal to the number of neurons. These neurons are arranged a priori on a fixed grid with a 1D, 2D or 3D topology (Szantó et al. 2008).

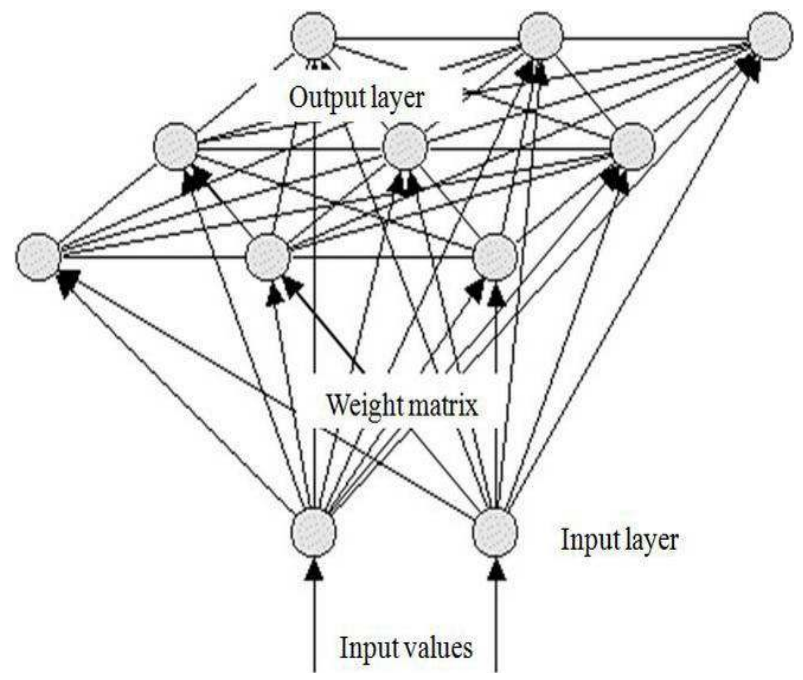

Figure 3.4 Self-organizing map (Szantó et al. 2012)

The training takes place according to the Kohonen rule, where the processing units learn competitively. After initializing the weights for each neuron, a random sample case is fed to the net. The model searches for the weight vector of the most similar i.e. the winning neuron in each input sample. This is usually calculated on the basis of Euclidean distance. Then the weights of the winning neurons and the ones within a certain topological distance are adapted slightly to move towards the input sample. These focal modifications over the course of many iterations are causing similar input data to be associated with closely positioned neurons. The size of the modifications of the weights decreases with time and the training stops after a predetermined number of iterations (Villmann et al. 2003).

The different types of visualization of the output model make the analysis of the results possible. When the distribution of the input sample in the data space is examined, the position of the neurons in the data space, their distances from each other or from the component planes can be visualized. The component planes represent the strength of the neuron weights regarding each variable. Through examination of the similarity of the component planes, the connections between the variables can be detected (Szantó et al. 2008).

- Adaptive Resonance theory

Most ANN are working in such a way, that after having trained the system, the weights are fixed, and the network is fed with new data. The boundaries of the problem domain are considered stable. 
In real world applications however, often the problem domain does not have well-defined boundaries and is not stable. To adapt to changing patterns the network needs to be retrained with the new patterns as well as with the old patterns. To solve these problems, the adaptive resonance theory has been developed, which has a feedback mechanism between the competitive layer and the input layer of a network. This feedback mechanism facilitates the learning of new information without destroying old information. The results from this approach are two neural-network architectures that are particularly suited for pattern-classification problems in realistic environment (Freeman \& Skapura 1991, Tso \& Mather 2009).

- Hamming network

A Hamming network is an example of a competitive learning network that was explicitly designed to solve binary pattern recognition problems. It is a combination of a feed forward network and a recurrent net. It is called Hamming network because the neuron in the feed forward layer with the largest output (calculated by the inner product of the weights and the prototype pattern) will correspond to the prototype pattern that is the closest in Hamming distance (= the number of elements that are different between two binary vectors) to the output pattern. The output of the feed forward layer is the input for the recurrent layer. Here, the neurons compete. The winning neuron is the only non zero neuron. This neuron indicates what input was given to the network (Hagan et al. 1996).

\section{- Hopfield net}

A Hopfield net is designed to mimic physical memory. It has only one layer, but all neurons in this layer are fully interconnected through double weighted links going in both directions (Lara 1998). Therefore, the network is a recursive network. An important application of Hopfield nets is associative memory which is useful to regenerate incomplete signals or noise corrupted ones (Gurney 1997).

\subsection{Activation functions}

Activation or transfer functions determine if and how strong a neuron should pass on a signal to the next neurons (in the next layer), or in other words, how much of weighted input of the incoming signals is transferred further. They are processing the net output $n$ of the input neurons to determine the neural output $a$ (Fig. 3.3). A number of functions and variations on functions exist. It depends on the application which transfer function is best suitable (Hewitson \& Crane 1994). For the backpropagation algorithm it is required that the activation function is differentiable, therefore this training algorithm normally uses a sigmoid activation function (see $\S 3.5$ ). The most commonly used functions are the Hard Limit, Linear and Sigmoid functions. 
The Hard Limit activation function is a threshold or binary function that gives output $\mathrm{a}=0$ if $\mathrm{n}<0$ and $\mathrm{a}=1$ if $\mathrm{n} \geq 0$. It is sometimes referred to as a threshold logic unit (TLU) (Zurada 1992). Its mathematical expression is:

$$
a= \begin{cases}0, & n<0 \\ 1, & n \geq 0, \quad \text { with } n \in \mathbb{R} \text { (Hard Limit activation function) }\end{cases}
$$

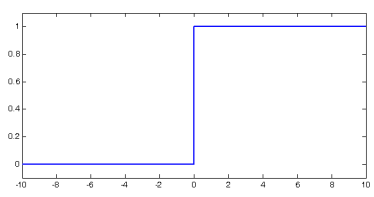

A second commonly used activation function is the Linear Function, where the neural output is equal to the net output. This is a continuous bipolar function, because it produces both positive as well as negative responses (Zurada 1992). Its expression is:

$a=n, \quad$ with $n \in \mathbb{R}$ (Linear activation function)

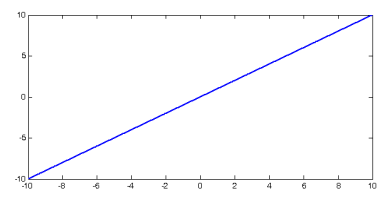

The third activation function is the Log-Sigmoid function. It maps the outputs away from the extremes and it introduces nonlinear behaviour to the network (Dawson \& Wilby 2001). These activation functions are used in the backpropagation training algorithm, where the easy differentiability of the function feature is used to calculate the gradient of the function (see $\S 3.5$ ):

$a=\frac{1}{1+e^{-n}}$ with $n \in \mathbb{R}$ (Unipolar Log-Sigmoid activation function)

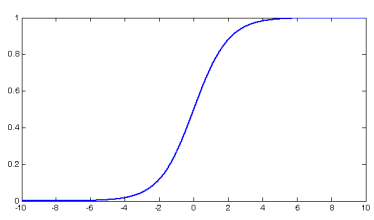

The Log-Sigmoid activation function is an example of a unipolar continuous function because its response is always positive. The bipolar version of the Log-Sigmoid function is given by:

$a=\frac{2}{1+e^{-n}}-1$, with $n \in \mathbb{R}$ (Bipolar Log-Sigmoid activation function)

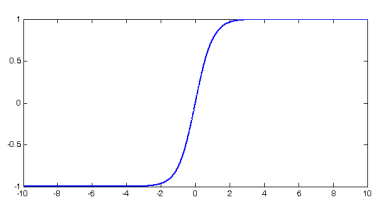

The Gaussian activation function (which is a type of radial basis function) is given by:

$a=e^{-n^{2}}$, with $n \in \mathbb{R}$ (Gaussian activation function)

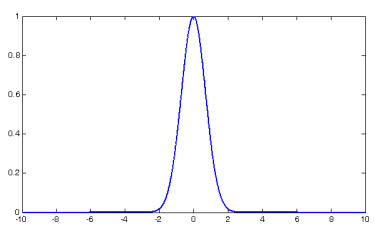

A larger list of activation functions can be found in e.g. Hagan et al. 1996, Hewitson \& Crane 1994 or Duch \& Jankowski 2001. 


\subsection{Training types}

The process of teaching a neural network how to solve a given problem is called teaching or learning. The algorithms that are used are called training or learning rules. A network is trained by adjusting the weights that link its neurons. This is accomplished by presenting the network with a set of training samples, which consist of a specific input and a related output response. Several algorithms have been developed to train artificial neural networks. A small subset of the most common training algorithms is discussed here. A more extended discussion can be found in e.g. Zurada 1992.

\section{- Delta rule of Widrow and Hoff}

In one of the simplest ways to train a network, the new weight $w_{\text {new }}$ is set equal to the old weight $w_{\text {old }}$ plus a correction term proportional to the difference between the desired output $t_{i}$ and the calculated output $a_{i}$ :

$$
w_{\text {new }}=w_{\text {old }}+\eta\left(t_{i}-a_{i}\right)
$$

where $\eta$ is the learning rate, a constant smaller than 1 . The learning rate is a method to optimize the learning algorithm. It governs how big the changes are to the weights and, hence, how fast the learning takes place (Gurney 1997). The new weight is larger than the old one, if the desired output is larger than the calculated output. If the desired output is smaller, then the weight becomes smaller. At the start of the training all weights are set to a random number. Iteratively, the weights are adapted until they are not changing anymore (Lara 1998). This rule is called the Delta rule of Widrow and Hoff and it is only possible to use it to train single layers networks, so it is not possible to use them to solve nonlinear problems (Hagan et al. 1996).

\section{- Backpropagation algorithm}

The backpropagation is the most popular learning algorithm (Malvic \& Prskalo 2007). It is one of the main reasons for the comeback of interest in artificial neural networks during the 1980s; because it allows for the straight forward training of MLPs. (Rumelhart et al. 1994). The algorithm randomly selects the initial weights and then calculates an output based on a set of inputs. The calculated outputs are then compared to the expected output and the error is calculated. Subsequently, the weights are adapted based on the errors in such a way that the total error is distributed among the neurons in the network (Yang \& Rosenbaum 2001). To be able to calculate the effect of the change of the individual weights the first derivative of the activation function is needed. This requires that the activation function is differentiable. The process of feeding forward signals and back-propagating the errors via the output layer to the hidden layer is repeated iteratively until some targeted minimal error is achieved between the desired and actual output values of the network (Dawson \& Wilby 2001, Pijanowski et al. 2002, Pradhan et al. 2010a). The weights are then stored to retain the knowledge in the network. The significance of this process is that, as the network trains, the nodes in the intermediate layers organize themselves such that 
different nodes learn to recognize different features of the total input space. After training, when presented with an arbitrary input pattern that is noisy or incomplete, the neurons in the hidden layers of the network will respond with an active output if the new input contains a pattern that resembles the feature the individual neurons learned to recognize during the training. Conversely, hidden layer neurons have a tendency to inhibit their outputs if the input pattern does not contain the features that they were trained to recognize (Hagan et al. 1996, Freeman \& Skapura 1991).

A short and simplified, description of the steps and equations involved in the backpropagation training algorithm of a network with one input layer, one hidden layer and one output layer is given in Annex 1.

The basic backpropagation method is robust but slow. This has encouraged considerable research on methods to accelerate the convergence of the algorithm. Apart from the use of a varying learning rate and the error gradient descent method (Malvic \& Prskalo 2007, Dawson \& Wilby 2001, Amini 2008, Gurney 1997), the momentum coefficient has been in use. The momentum coefficient defines the size of the previous iteration`s influence on the new estimation. (Malvic \& Prskalo 2007), which results in faster convergence.

\section{- Levenberg-Marquardt training}

The Levenberg-Marquadt (LM) algorithm is a numerical optimization technique for the backpropagation procedure (Hagan et al. 1996). It differs from it, in that the least square error calculation is optimized for speed, and therefore it is much faster than the backpropagation algorithm (Matlab Online help). An important drawback of the algorithm is that it needs to store a large matrix with the weights and biases internally. Because of this, its use is restricted to smaller single output networks using sum-squared error function (Bishop 1995).

A common problem with training is over-fitting. If a network is trained, that much that it can only respond to an input data set with the output data set that was used during the training it is called over-trained or hyper specialized. To prevent this and to retain a certain amount of generalization capability, training can be restricted in time and domain. By setting a certain minimum training error, the training time is reduced and the weights of the network are not adapted until they reach a perfect match. The domain covered by the input samples can be limited by selecting a subset of the possible input and output combinations. Due to such a reduced amount of input samples, overfitting of the network is avoided (Bishop 1995). Also, during the training a verification data set, which is a subset of the training set that is not used for training, is kept as an independent check on the progress of the training. As training progresses, the training error naturally drops. If the verification error stops dropping, or starts to rise, this indicates that the network starts to over fit the data, and training should stop (Mas et al. 2004). 
On the other hand, using a too narrow subset can also cause problems, because only those cases that were included in the training set will be correctly classified. Any other cases will be misclassified or not recognized (Malvic \& Prskalo, 2007, Zhou 1999). This means that the training subset should incorporate the extremes in the simulation data set as well.

\subsection{Application of artificial neural networks in geography and their combination with geographic information systems}

Artificial neural networks have been used successfully in many applications and fields of science. They can be characterized by the following set of properties (After Hewitson \& Crane 1994, Atkinson \& Tatnall, 1997, Thirumalaiah \& Deo1998, Zhou 1999, Krasnopolsky \& Chevallier 2003, Villman et al. 2003, Qiu \& Jensen 2004, Lakes et al. 2009, Pradhan et al. 2010a):

Advantages:

- Artificial neural networks are more or less independent of the statistical distribution of the data. Compared to traditional statistical methods (maximum-likelihood classification, in particular, see $\S 4.3$ ), neural networks allow the target classes to be defined without much consideration to their distribution in the corresponding domain of each data source, in other words the output classes do not have an assumed probability distribution

- ANN can be applied when the underlying problem is either poorly defined or not clearly understood

- Their application does not require a priori knowledge of the underlying process

- They are importance free. When neural networks are used, data sources with different characteristics can be incorporated into the process of classification without knowing or specifying the weights on each data source. This makes them suitable for research where it is not known or possible to know what the interrelationships between the different input factors are

- They are able to accurately approximate complicated nonlinear input/output relationships

- To a certain extent missing or low quality input data can be overcome by other neurons

- They are suitable for integrating data from different sources

- They are capable of handling large amounts of data

- Once trained, they are faster than most other approaches

Disadvantages:

- Artificial neural networks need to be trained

- They are computational expensive during the training phase

- Due to the initial random assignment of the weights, the results vary

- Some of the input parameters, like the number of layers and the number of neurons per hidden layer can only be determined by experimentation 
- ANNs do not require a priori knowledge of underlying processes. Instead, they aim to recognize patterns that result from such processes and hence do not offer new insights into functional relationships

- Neural networks are often considered as a "blackbox", because it is often difficult to understand the underlying processes

Artificial neural networks have been applied in many geographic analyses ranging from cropland change (Lakes et al 2009), prediction of porosity of geological formations (Malvic \& Prskalo 2007), calculation of vegetation indices based on different reflectance products (Verger et al. 2008), real time flood forecasting (Thirumalaiah \& Deo 1998), coordinate transformation (Barsi 1999) and suitability of local environments for specific tree species (Hilbert \& Ostendorf 2001). Furthermore, Veres (2002) used a RBF neural network to calculate elevations based on sets of (x,y,z) coordinates. Zaletnyik (2007) compared the results of a WGS84 - EOV transformation calculated with a RBF neural network and a polynomial based approximation method. Hungarian regions were classified by Farkas (2010) using a SOM, and Horvath (2011) applied a SOM to identify a depositional body. Especially, studies in the field of remote sensing extensively used ANN to classify imagery. Atkinson and Tatnall (1997) reviewed a variety of remote sensing applications and ANNs. Some examples of more recent publications are Vilas et al. (2011), who used MERIS satellite imagery to estimate chlorophyll in coastal waters using a multilayer perceptron, Pacifici et al. (2009) who extracted textural features from Quickbird and Worldview-1 very high resolution panchromatic images using a neural network. Barsi et al. (2010) performed an unsupervised classification on a Quickbird very high resolution satellite image using a SOM. Khan (2005) classified four Landsat scenes with a neural network for the purpose of change detection. Chen et al. (2011) used satellite derived indices to feed to a neural network to estimate the vegetation cover, which was used as input in soil erosion modelling. Schlerf \& Arzberger (2006) used a multilayer perceptron to estimate canopy reflectance from Hymap airborne hyperspectral data. Many remote sensing and ANN studies compared the results of an ANN with the results of more traditional classification and regression techniques. For example, Barsi (1997) classified Landsat satellite images using different neural networks and traditional maximum likelihood classification and found comparable accuracies for both methods. Mutanga \& Skidmore (2004) found better results for mapping of savannah grass nitrogen concentration using a neural network based on hyperspectral data than with traditional multiple linear regression. Masocha \& Skidmore (2011) compared results of a neural network and other nonlinear classifiers to map invasive species using a combination of satellite and GIS layers. They found that combining different methods yields the highest accuracy.

The combination of artificial neural networks and geographic information systems provides a new set of opportunities. Several studies have followed this approach. Skidmore et al. (1997) experimented with many different settings of a neural network with a backpropagation training algorithm to map an eucalypt forest based on Landsat imagery and GIS data, Yang \& Rosenbaum 
(2001) combined an ANN and GIS to assist decision support for engineering problems and harbour management. They developed a method to compute the strength of the contributing factors to a system. A multilayer perceptron with backpropagation in Matlab was connected to GIS layers in ArcGIS by Tayyebi et. al. (2011) and by Pijanowski et. al. (2009) to predict urban growth. Earlier Pijanowski et al. (2002) used a combination of GIS and ANNs to forecast urban landuse changes based on a set of anthropogenic predictor values. They describe ANNs as part of a group of models that aim to establish functional relationships between a set of spatial predictor variables that are used to predict the locations of change on the landscape. Pradhan et al. (2007, 2010a, 2010b) used a combination of a multilayer perceptron with backpropagation in Matlab and GIS layers that were preprocessed in ArcGIS. They applied their network to a large set of physical geographical factors to predict the occurrences of landslides in Malaysia. To facilitate the input and output of GIS data, the Matlab algorithm was adapted. Dai et al. (2005) used an artificial neural network for sensitivity analysis of the explanatory values of a land use change model. Mas et al. (2004) combined a MLP and GIS data for predicting tropical deforestation, Choi et al. (2012) combined parameters derived from ASTER DEM with other GIS layers to calculate landslide susceptibility maps. Moonjun et al. (2010) used a feed forward network in ENVI image processing software to determine soil classes based on a set of GIS layers. Yeh \& Li (2003) used GIS layers to feed a combined ANN-cellular automata network to simulate urban development patterns, and Ni \& Xue (2003) developed a GIS and ANN flood prediction model and emphasize the important of integration of data as well as functions.

The mentioned examples show the importance and advantages of integration GIS and ANN functionality. The research presented in this dissertation goes beyond the earlier examples, since it fully integrates the artificial neural network into the GIS as is shown in chapter 5. 


\section{Identification and classification of inland excess water}

\subsection{Study area}

The Great Hungarian Plain covers an area of $52000 \mathrm{~km}^{2}$. From this region, the Tápai-rét area was selected as the study area for this research (Fig. 4.1). The area was formed by fluvial processes, as is illustrated by the abandoned meanders, natural levees, point-bar systems, scour channels and swales of the Maros and Tisza Rivers (Mezősi 1983, Benyhe \& Kiss 2012). The study area is about $20 \mathrm{~km}^{2}$ large and the relative relief energy is low, approximately $1,86 \mathrm{~m} / \mathrm{km}^{2}$ including artificial structures like dikes and roads. There are no natural areas that are considerably higher than their surroundings. In the area, mainly agricultural activity takes place although there are also many oil wells of MOL, the Hungarian oil company. The common soil type in the area is a combination of fluvisols and meadow soils with clayey or silty texture (Keveiné Bárány 1988, Marosi \& Somogyi 1990). The average ground water level varies between 2 and 4 meters below the surface. The groundwater may reach the surface only in the former meanders. A network of agricultural roads has been artificially elevated and is running north to south and east to west dividing the area into rectangular shaped plots. The drainage channels usually run parallel along both sides of the roads, and their density is about 2,92 km/ $\mathrm{km}^{2}$ (Benyhe \& Kiss 2012).
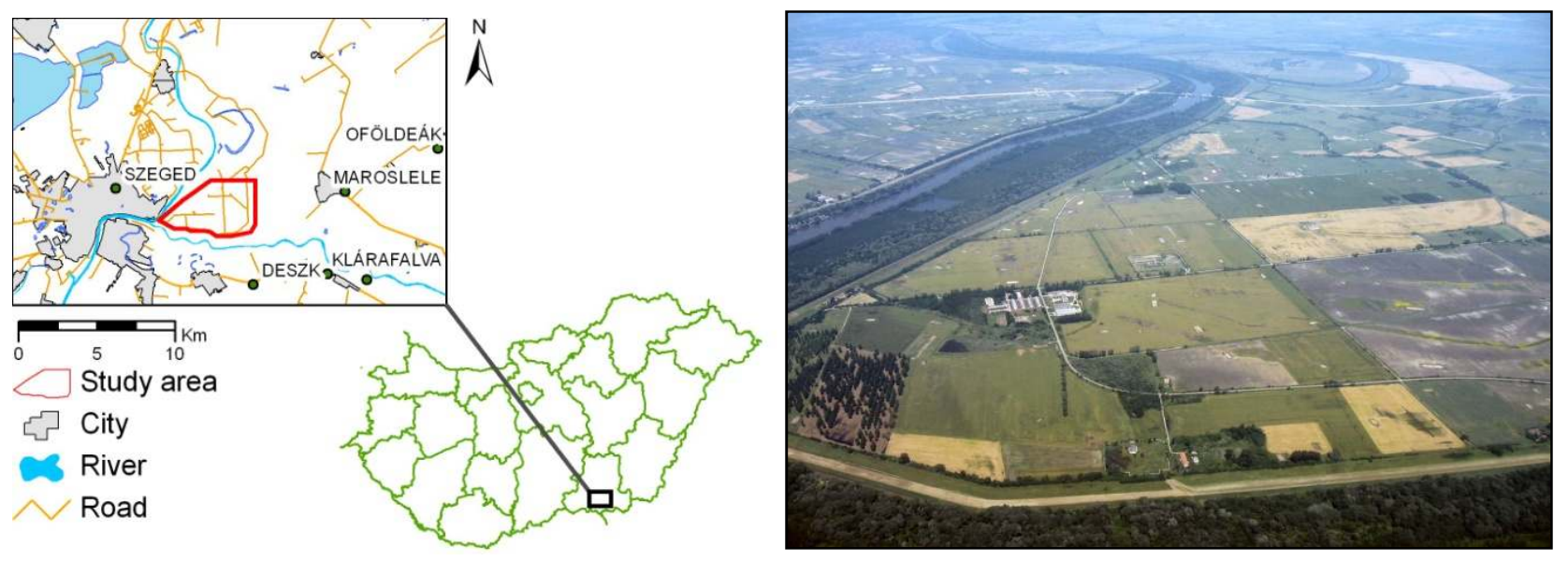

Figure 4.1 Location (left) and an oblique overview photograph of the Tápai-rét study area (right)

The area is suitable for inland excess water research for two main reasons:

- The soils in the study area show extreme mechanical properties: in large areas, the plasticity index according to Arany $\left(\mathrm{K}_{\mathrm{A}}\right)$ is above 60 . The exceptionally bad permeability characteristics combined with the very flat terrain with large local depressions, without runoff result in high vulnerability to inland excess water accumulation.

- The Department of Physical Geography and Geoinformatics has a long standing inland excess water research program in the area. This means that lots of data and knowledge about the area are available. Furthermore, the area is close to the airport of Szeged from where the 
data acquisition campaigns are executed. Since inland excess water is a phenomenon with strong temporal characteristics, it is important to acquire data for research in time.

In the study area, one region was selected as "training" region, where the ANN was trained. A second area was used as "simulation" region (Fig. 4.2). In the simulation phase, data from this area was classified with the trained neural network. The training region is 99 ha and the simulation area is 73 ha. The regions have an overlap of 8 ha.

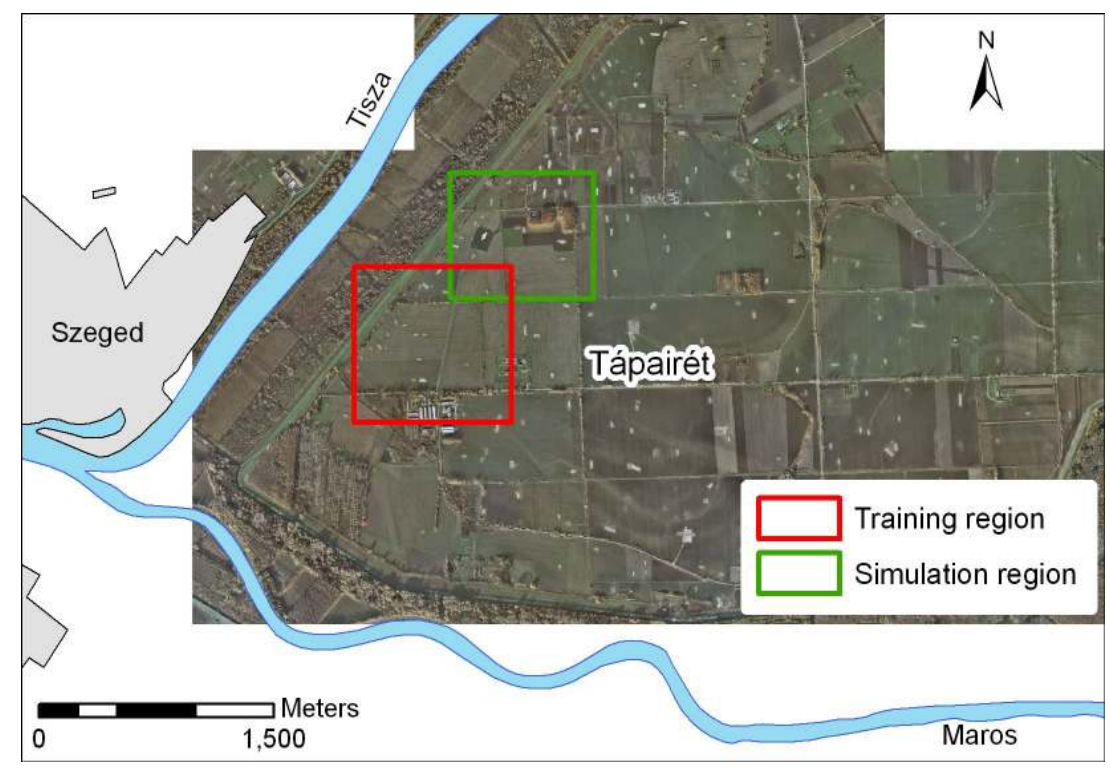

Figure 4.2 Training and simulation regions with a mosaic of DMC aerial photographs of the Tápai-rét area as background

\subsection{Source data}

For this study, a multitude of remote sensing and GIS data has been collected and processed. The data consists of (1) existing databases that were converted to fit the requirements of this research, of (2) data that was acquired using in-house developed acquisition methods and (3) data that has been bought from external sources. Table 4.1 gives an overview of the different data sets.

Other input data that could influence the formation of inland excess water were not incorporated for several reasons. First, soil measurement showed everywhere in the area poor permeability characteristics and differences in other characteristics were also minimal. Therefore, soil is considered homogeneous in the study areas. The lithology is also considered to be homogeneous throughout the area. A groundwater-precipitation-evapotranspiration measuring station in the study area provides hourly data of many parameters (Barta 2012). These parameters show that the precipitation, evaporation and infiltration result in a surplus of water during the inland excess water periods. Vegetation is not homogeneously distributed over the area, but was not introduced as a separate input layer to the network, because its distribution is represented by the colour infrared images. 
Table 4.1 Input and output data used in this research

\begin{tabular}{|l|l|}
\hline Data set & \multicolumn{1}{|c|}{ Source } \\
\hline $\begin{array}{l}\text { CIR (Colour- } \\
\text { Infrared) imagery } \\
\text { (4.2.1) }\end{array}$ & $\begin{array}{l}\text { Colour infrared images were acquired on March 24 and June 9, 2010 } \\
\text { with a MS3100 digital camera. }\end{array}$ \\
\hline $\begin{array}{l}\text { LIDAR Digital } \\
\text { elevation model } \\
(4.2 .2)\end{array}$ & $\begin{array}{l}\text { On 19 November 2009, LIDAR data was collected during a flight } \\
\text { campaign. Simultaneously, stereo colour and near infrared aerial } \\
\text { photographs were collected. }\end{array}$ \\
\hline $\begin{array}{l}\text { Soil characteristics } \\
(4.2 .3)\end{array}$ & $\begin{array}{l}\text { The Agrotopo spatial soil information system (1:100 000) and 2 Kreybig } \\
\text { soil map sheets (1:25 000) }\end{array}$ \\
\hline $\begin{array}{l}\text { Anthropogenic } \\
\text { objects (4.2.4) }\end{array}$ & $\begin{array}{l}\text { Channels, roads, buildings and oil wells were digitized based on the } \\
1: 10 \text { 000 topographic map from 1984, the LIDAR based digital elevation } \\
\text { model (Nov 2009) and colour aerial photographs from the DMC camera } \\
\text { (Nov 2009) }\end{array}$ \\
\hline $\begin{array}{l}\text { Field measurements } \\
(4.2 .5)\end{array}$ & $\begin{array}{l}\text { On March 5, 2010, a fieldwork was executed to collect inland excess } \\
\text { water ground truth data using hand-held GPS systems. }\end{array}$ \\
\hline
\end{tabular}

\subsubsection{Colour infrared images}

Since February 2008, an advanced system to acquire digital images in the visible to near infrared and thermal wavelengths has been under development at the department of Physical Geography and Geoinformatics of the University of Szeged (Tobak et al. 2008a, Tobak et al. 2008b, van Leeuwen et al. 2009b, Unger et al. 2010). The core of the system consists of a Duncantech MS3100 small format CIR (Colour-InfraRed: Green - Red - Near Infrared) multi-spectral camera (Fig. 4.3).

The MS3100 camera is a 3-CCD (charge-coupled device) system with independent gain controls for each CCD. The standard acquisition software from the camera vendor is used to control the instrument. The camera operator has a real-time view of what the camera captures during the flight and can control the gains, integration time, and frame rate in flight. The camera uses a $4.65 \times 4.65$ micron CCD to capture data at a resolution of $1392 \times 1040$ pixels per band, and has a 10-bit per band dynamic brightness range.
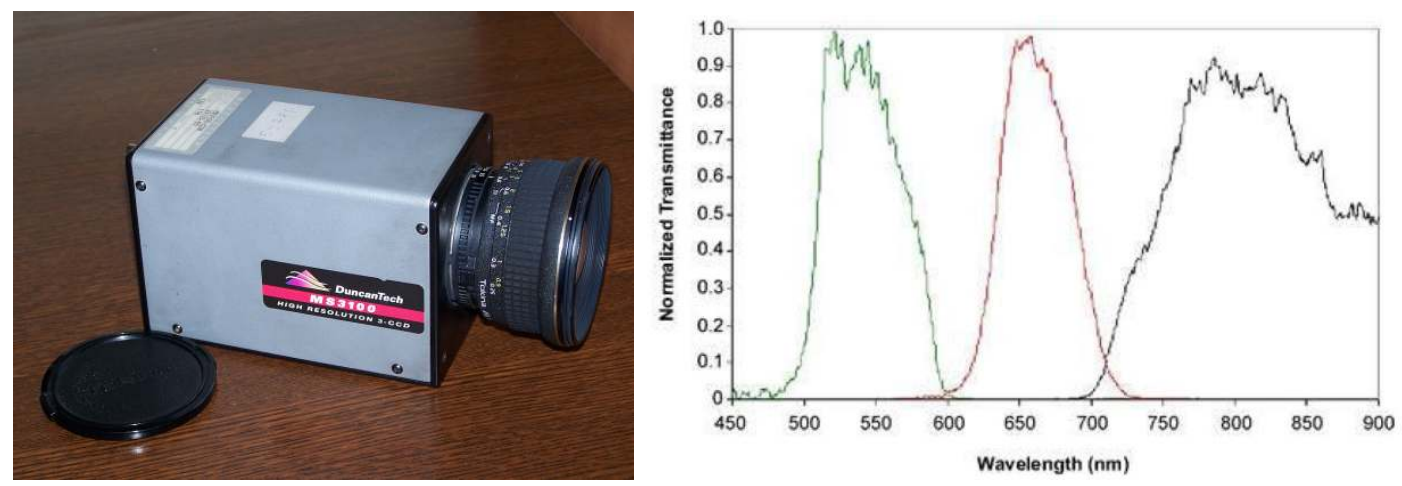

Figure 4.3 Duncantech MS3100 CIR Camera and its three spectral response curves in green red and near infrared (source: www.terraverdetech.com) 
A National Instruments IMAQ 1428 frame grabber in a Windows based minicomputer converts the continuous stream of data collected by the camera into digital images which are stored on a local hard disk. A GPS receiver is used to mark the approximate center point of each photo as it is taken. The registered GPS position includes a small error due to the difference in position of the antenna and the camera, but also a much larger positional error of the image center can occur due to the plane's pitch and roll. This error mainly depends on the weather conditions during the flight, and is, at the typical flying height of 1500 meter about 26 meter per 1 degree roll or pitch. The center coordinates are logged in a simple ASCII file that is later used to create a coarse georeference for each image.

Ahead of the flight, a detailed flight plan is created and stored as a digital map in a mobile GPS receiver (a Mobile Mapper CE). In the air, a navigator directs the pilot to follow the flight plan as accurately as possible. It is important to follow the plan accurately since small deviations can result in a too large overlap between adjacent flight lines or worse, it can result in missing data between adjacent flight lines. After the flight, the GPS track which was recorded during the flight and the original plan are compared to determine possible errors.

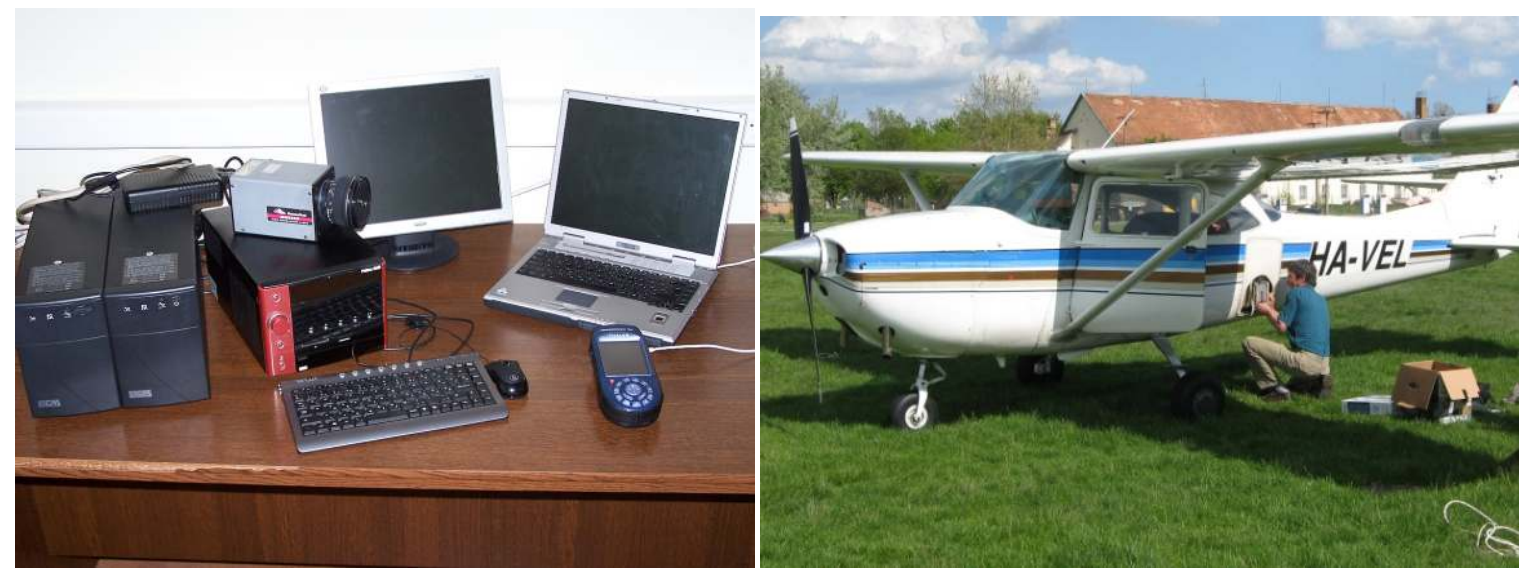

Figure. 4.4 The multi-spectral acquisition system (left) and the Cessna 172 airplane (right)

The complete acquisition system (Fig. 4.4) consists of the camera, a mini computer for data storage and operation of the camera, a monitor, two handheld GPS systems, a laptop for the camera operator to follow the flight path and a 12 Volt power supply. All equipment is built into a fourseated, single engine Cessna 172 airplane.

A complex processing workflow was developed to be able to convert the raw images into useful base data (Fig. 4.5). The raw acquisition data does not come with any georeference because no inertial data is acquired during the flight. To be able to use the data in combination with other georeferenced sources, a coarse georeference is generated by using positional data collected during the flight and the time the images were acquired. 


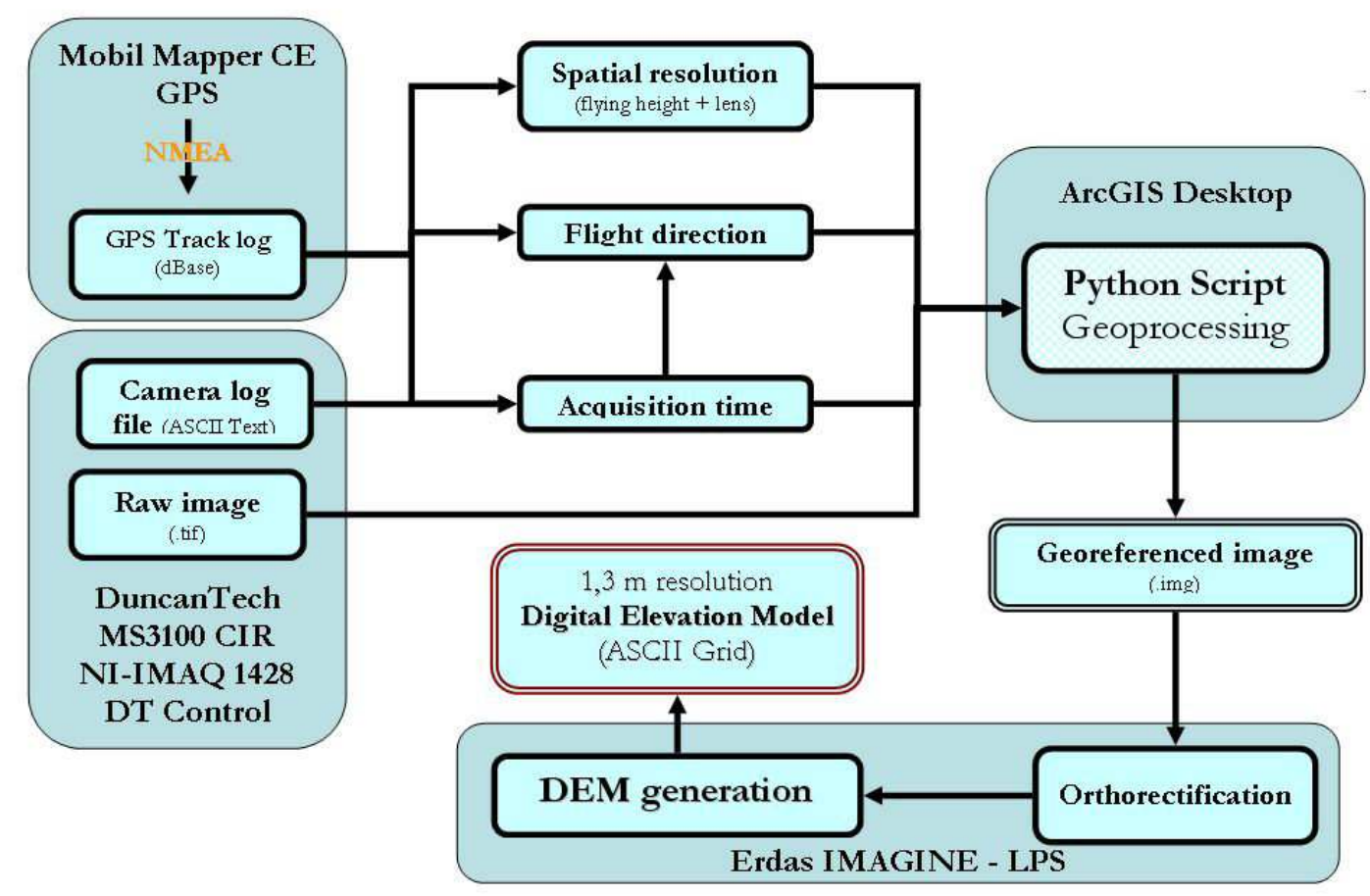

Figure 4.5 Flow chart showing the CIR image processing steps (van Leeuwen 2009a)

When the area covered by inland excess water was at its maximum, on March 24 and June 9, 2010, two flights were executed. During the flight campaigns respectively 892 and 898 images were collected from a flying height of 2000 meters. Each individual image covers an area of about $860 \mathrm{x}$ 640 meter and has an average spatial resolution of 0,62 meter (Fig. 4.6 left).
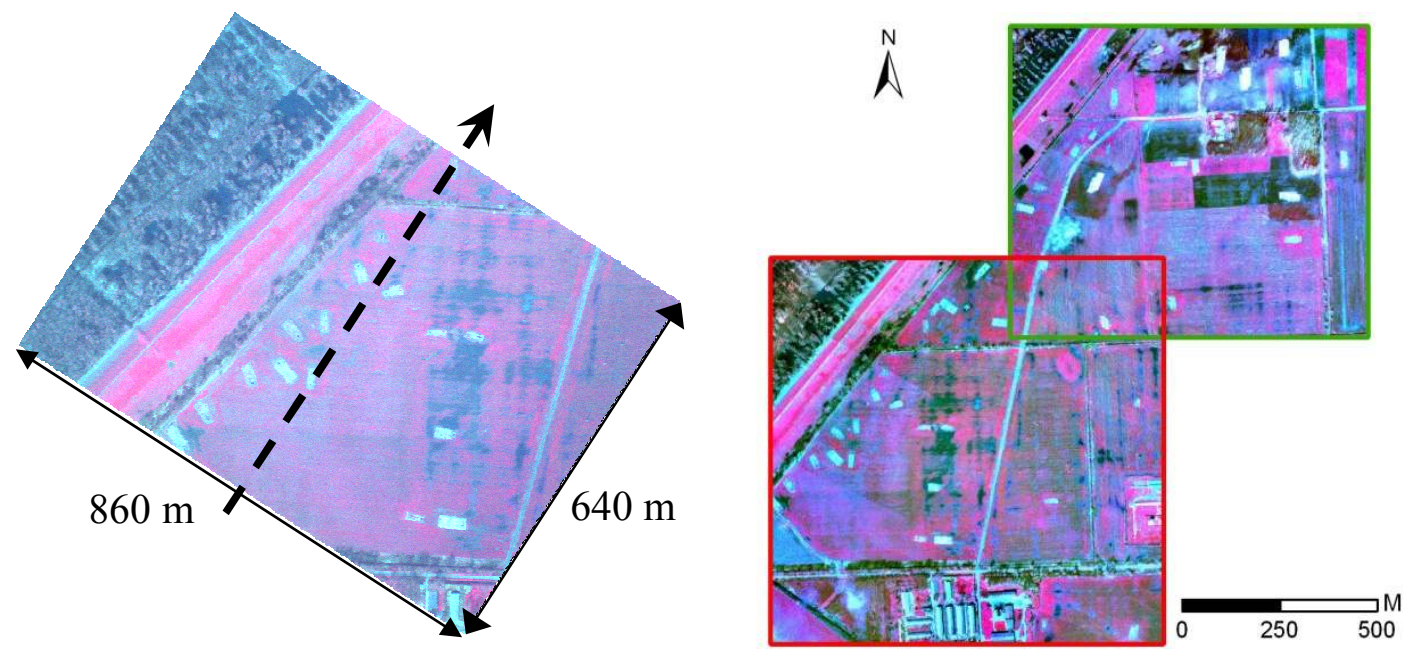

Figure 4.6 A single CIR image (left) and the March 24, 2010 mosaic of the training and simulation regions (right) (van Leeuwen et al. 2010)

From both flight campaigns a mosaic was created covering the training and simulation regions (Fig. 4.6 right). This was done by carefully georeferencing the single geocoded images to high resolution DMC orthophotos (see $\S$ 4.2.2). The georeferenced images were then colour balanced (histogram 
matching) to overcome illumination differences and were finally mosaicked together into the threeband colour infrared image as shown in figure 4.7.

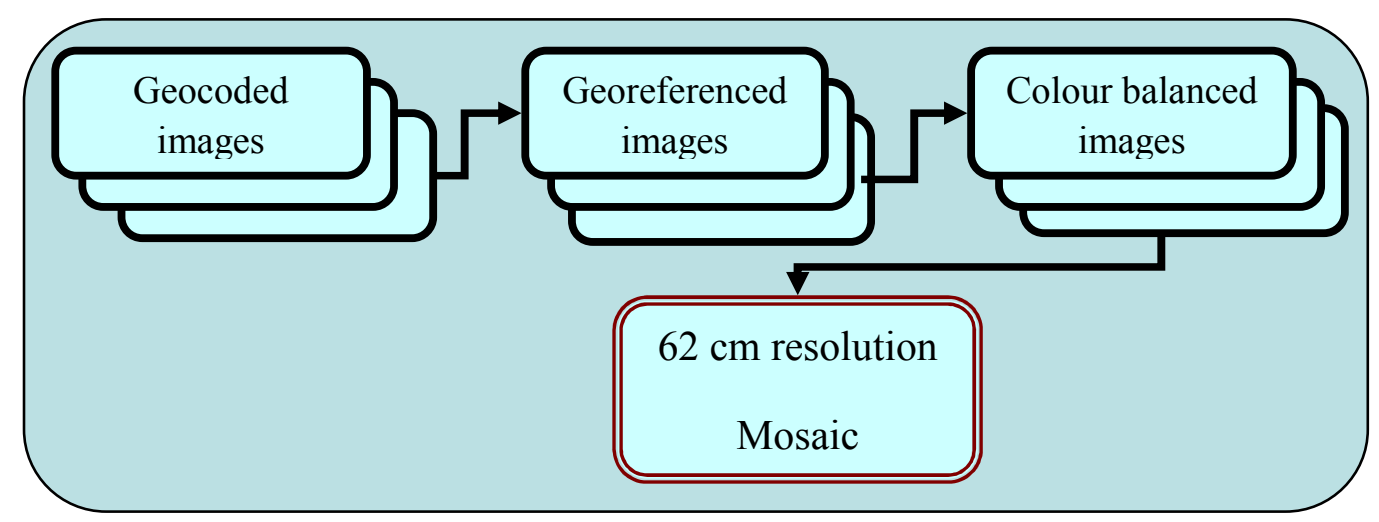

Figure 4.7 Preprocessing workflow of the CIR images

\subsubsection{Local depressions derived from a LIDAR based digital elevation model}

One of the most important factors in inland excess water analysis is the relief. Since there are only very small height differences involved in the occurrences of the inundations, it is important to use a very high resolution digital elevation model (DEM). In Hungary, the highest resolution DEM available for the whole country is the DDM-5 model with a horizontal resolution of 5 meter and a vertical accuracy of ca. 1 meter. The geomorphological forms, important in inland excess analysis, are not visible at this accuracy. Also digital elevation models derived from the contours of the 1:10 000 topographic maps do not have sufficient accuracy to be used in this study. To overcome this problem, on November 19, 2009, an airborne laser scanning flight campaign was executed to collect LIDAR data over three areas in the south-east of Hungary. From a flying height of 1500 meters, $70 \mathrm{~km}^{2}$ of terrain was surveyed with an average point density of 1,4 points $/ \mathrm{m}^{2}$. In total 106 million points were measured. The accuracy of the LIDAR points was evaluated on two test areas for a total number of points of 15000 . The RSME error for all points was $4,6 \mathrm{~cm}$, while $99,76 \%$ of them were within the specified vertical system accuracy of $15 \mathrm{~cm}$. The maximum vertical error was $22 \mathrm{~cm}$ (Szatmári et al. 2012).

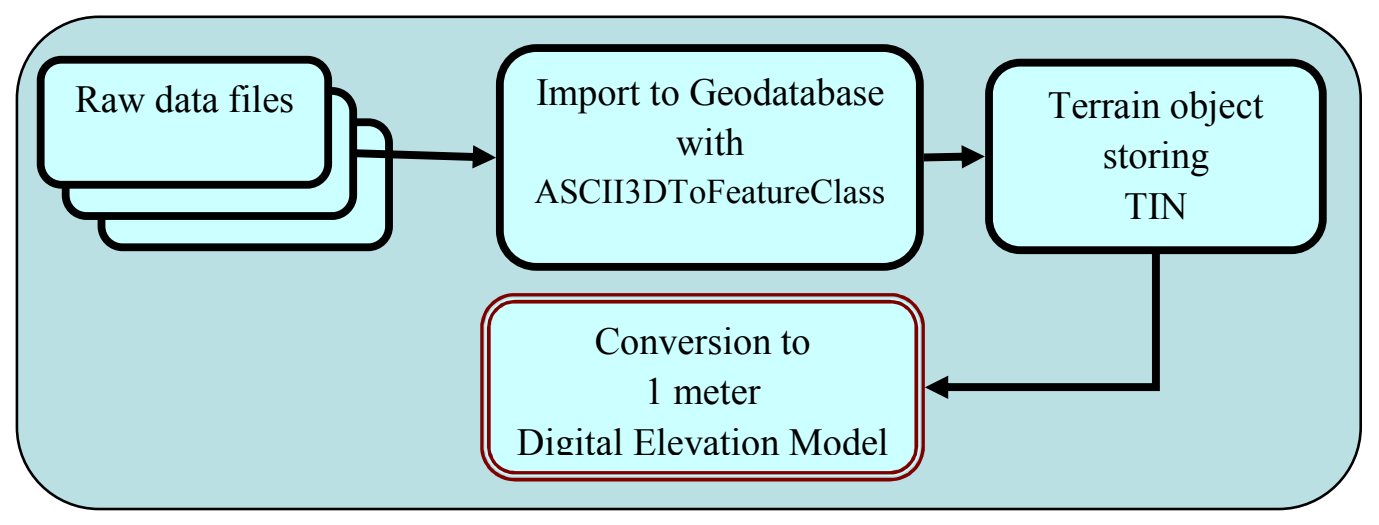

Figure 4.8 Raw LIDAR data to digital elevation model processing workflow 


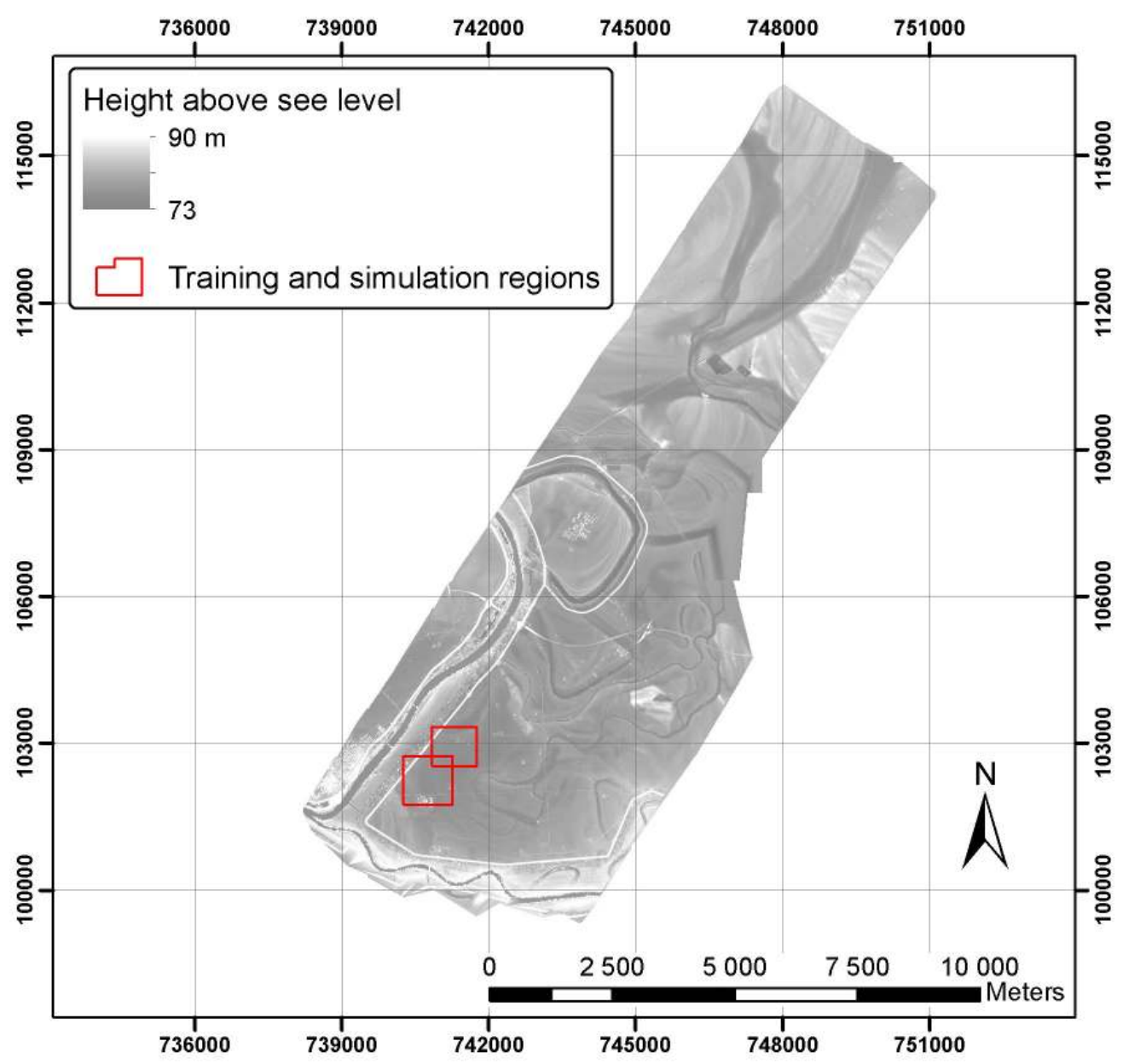

Figure 4.9 LIDAR based digital elevation model with the two study regions

At the same time of the height recordings, stereo near infrared and colour aerial digital photographs were collected with a digital mapping camera (DMC). The resolution of the aerial photographs is 15 $\mathrm{cm}$. The images were collected with a $60 \%$ overlap in the flight direction and $30 \%$ overlap between consecutive flight lines. Images were geometrically corrected using geodetic control points that were highlighted on the ground and with selected points that were measured with geodetic instruments after the flight (Szatmári et al. 2011b).

Based on the stereo images, linear features were digitized in three dimensions using stereo photogrammetic techniques. These break lines were converted to points and integrated with the original LIDAR measurements, providing more accurate height information for anthropogenic structures in the terrain. In total about 5000 buildings and $700 \mathrm{~km}$ of linear features were extracted (Szatmári et al. 2011a).

The raw LIDAR points and the 3D points were converted to a digital elevation model (Fig. 4.8). The raw points were imported into a 3D feature class in a geodatabase. From the feature class, a terrain object was created storing a multi-resolution Triangulated Irregular Network (TIN). Finally, the TIN was converted to a DEM with a horizontal resolution of 1 meter using the nearest neighbour linear interpolation method (Fig. 4.9). 


\subsubsection{Soil characteristics}

The soil characteristics in the study area have been measured during several field surveys by the Department of Physical Geography and Geoinformatics. At all three sample points in the area, a high plasticity index according to Arany $(\mathrm{Ka})$ was found $(\mathrm{Ka}>60)$. This indicates that the soil has poor permeability characteristics. The soil characteristics were also extracted from the two available Hungarian soil data bases Kreybig and Agrotopo.

Table 4.2 Soil characteristics according to the Agrotopo database

\begin{tabular}{|l|l|l|l|l|l|l|l|}
\hline \multicolumn{7}{|c|}{ Agrotopo (1:100 000) } \\
\hline Soil type & $\begin{array}{l}\text { Parent } \\
\text { material }\end{array}$ & Texture & $\begin{array}{l}\text { Clay mineral } \\
\text { composition }\end{array}$ & $\begin{array}{l}\text { Soil water } \\
\text { management } \\
\text { category* }\end{array}$ & $\begin{array}{l}\text { Soil } \\
\text { reaction } \\
\text { and } \\
\text { carbonate } \\
\text { status }\end{array}$ & $\begin{array}{l}\text { Organic } \\
\text { matter } \\
\text { content } \\
\text { (ton/ha) }\end{array}$ & $\begin{array}{l}\text { Depth of } \\
\text { the column } \\
\text { A }\end{array}$ \\
\hline $\begin{array}{l}\text { Meadow } \\
\text { soils }\end{array}$ & $\begin{array}{l}\text { Glacial } \\
\text { and } \\
\text { alluvial } \\
\text { deposits }\end{array}$ & $\begin{array}{l}\text { Clay } \\
\text { loam }\end{array}$ & Smectite & $\begin{array}{l}\text { Moderate IR, } \\
\text { poor P and } \\
\text { HC; high FC } \\
\text { and WR }\end{array}$ & $\begin{array}{l}\text { Slightly } \\
\text { acid soils }\end{array}$ & $200-300$ & $>100 \mathrm{~cm}$ \\
\hline $\begin{array}{l}\text { Meadow } \\
\text { alluvial soils } \\
\text { and alluvial } \\
\text { meadow } \\
\text { soils }\end{array}$ & $\begin{array}{l}\text { Glacial } \\
\text { and } \\
\text { alluvial } \\
\text { deposits }\end{array}$ & $\begin{array}{l}\text { Clay } \\
\text { loam }\end{array}$ & Smectite & $\begin{array}{l}\text { Moderate IR, } \\
\text { P and HC; } \\
\text { high FC and } \\
\text { good WR }\end{array}$ & $\begin{array}{l}\text { Slightly } \\
\text { acid soils }\end{array}$ & $100-200$ & $>100 \mathrm{~cm}$ \\
\hline Alluvial soil & $\begin{array}{l}\text { Glacial } \\
\text { and } \\
\text { alluvial } \\
\text { deposits }\end{array}$ & $\begin{array}{l}\text { Clay } \\
\text { loam }\end{array}$ & Smectite & $\begin{array}{l}\text { Moderate IR, } \\
\text { P and HC; } \\
\text { high FC and } \\
\text { good WR }\end{array}$ & $\begin{array}{l}\text { Slightly } \\
\text { acid soils }\end{array}$ & $50-100$ & $>100 \mathrm{~cm}$ \\
\hline
\end{tabular}

* IR: infiltration rate, P: permeability, HC: hydraulic conductivity, FC: field capacity, WR: water retention

The Kreybig soil data was collected based on 1:25 000 topographic base maps by the Hungarian Geological Institute during different periods between 1935 and 1951 (MTA ATK TAKI-Kreybig Soil map 2011, Szabó et al. 2000). Agrotopo - the Agrotopographical Database - is a national spatial soil information system maintained by the Research Institute for Soil Science and Agricultural Chemistry of the Hungarian Academy of Sciences (RISSAC HAS). The database was created between 1989 and 1992, based on 1:100 000 topographic maps sheets (MTA ATK TAKIAgrotopo 2011) and the before mentioned Kreybig maps.

Tables 4.2 and 4.3 show the characteristics of the different soil types in the study areas. According to both data sets the soils in the area have poor permeability characteristics and differences in other characteristics are minimal. 
Table 4.3 Soil characteristics according to the Kreybig maps

\begin{tabular}{|l|l|l|}
\hline \multicolumn{2}{|c|}{ Kreybig (1:25 000) } \\
\hline Main type & Chemical properties & Physical properties \\
\hline II & Alkaline and neutral soils & $\begin{array}{l}\text { Soils with high water retention and poor } \\
\text { permeability, and infiltration rate (heavy clay) }\end{array}$ \\
\hline II & Highly acid soils & $\begin{array}{l}\text { Soils with high water retention and poor } \\
\text { permeability, and infiltration rate }\end{array}$ \\
\hline II & Moderate acid soils & $\begin{array}{l}\text { Soils with high water retention and poor } \\
\text { permeability, and infiltration rate }\end{array}$ \\
\hline
\end{tabular}

\subsubsection{Distance to anthropogenic objects}

Anthropogenic objects that could influence the formation of inland excess water were digitized from 1:10 000 topographic maps and aerial photographs (Fig. 4.10). These objects were verified with fieldwork data and thematic maps were created. During fieldworks, it was noticed that inland excess water often occured in the neighbourhood of channels, but not directly next to them.

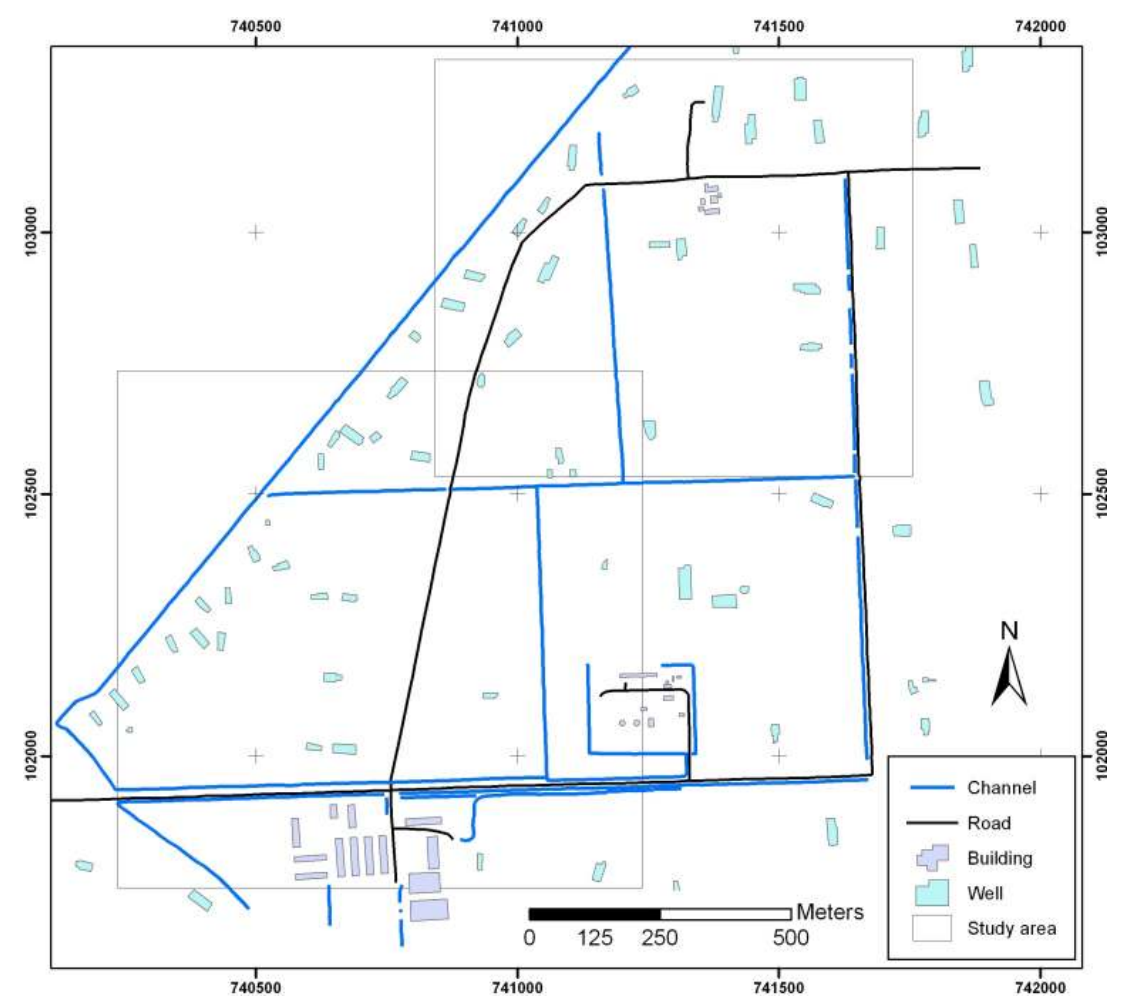

Figure 4.10 Anthropogenic objects in the study areas

The slope of the agricultural fields is normally oriented towards the channels but immediately next to the channels the terrain is often slightly higher, obstructing runoff into the channels (Fig. 4.11). These channel ridges were also observed, measured and described in detail by Benyhe \& Kiss (2012). 


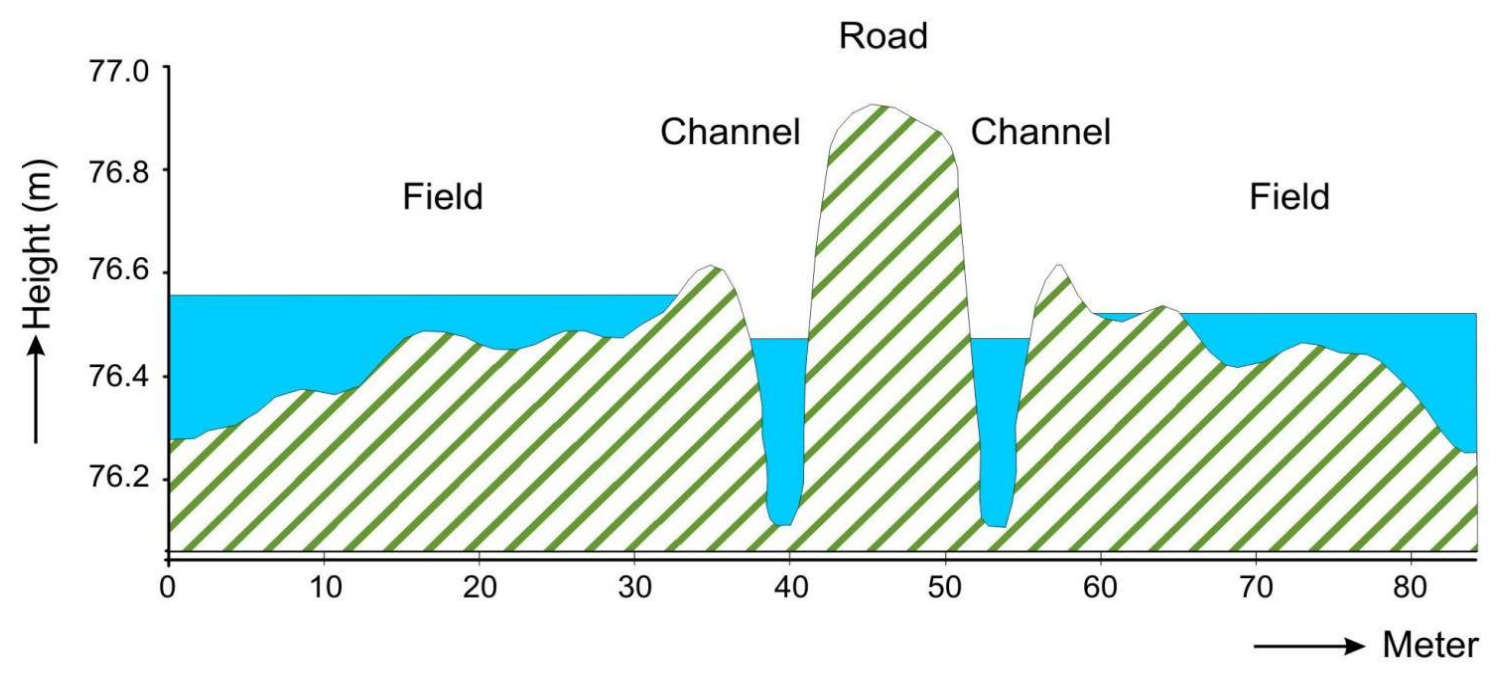

Figure 4.11 Schematic cross section of a field-channels-road-channel-road system

Furthermore, if channels are not maintained properly, surplus water will collect in the channels, but cannot be transported away, causing the channels to fill up and spill over. Finally, channel capacity can be insufficient to transport away enough surplus water. Then, the lowest areas directly next to the channels will get inundated. Other anthropogenic objects, like roads, oil stations and buildings were also taken into consideration, although their role in the formation of inland excess water is not that obviously visible in the terrain.

\subsubsection{Fieldwork measurements}

On four occasions fieldwork measurements were executed in the study area. The individual inland excess water patches were measured by walking around them with a GPS. On one occasion two different GPS receivers were used simultaneously by one person (to exclude differences in interpretation of the boundary of the water) to evaluate the differences in accuracy. Figure 4.12 shows the results. The GPS track of the Magellan MobileMapper was measured with 3-5 meters accuracy, while the Garmin Geko track was measured with 5-7 meters accuracy. The MobileMapper track consisted of 837 points, while the Geko recorded 843 points. The area of the largest inland excess patch was compared for both GPS devices. The area of the MobileMapper patch was $1.8 \%$ larger than the one from the Geko track. The length of the Geko track is $6.7 \%$ longer though. Since the area is more important in inland excess water analysis and the maps show little difference in the final inland excess patches, it was decided that both GPS receivers can be used to measure individual inland excess water occurrences accurately.

Accurate in situ measurements are often difficult to perform because of the conditions of the soil. When the inundations occur the soil is extremely saturated with water. This makes it physically difficult to walk around the individual patches (Fig. 4.13) and furthermore, it makes it difficult to decide where the border of the patch is. Therefore, it can be concluded that differences due to the accuracy of the GPS systems are smaller than inaccuracy caused by the data collection method. 

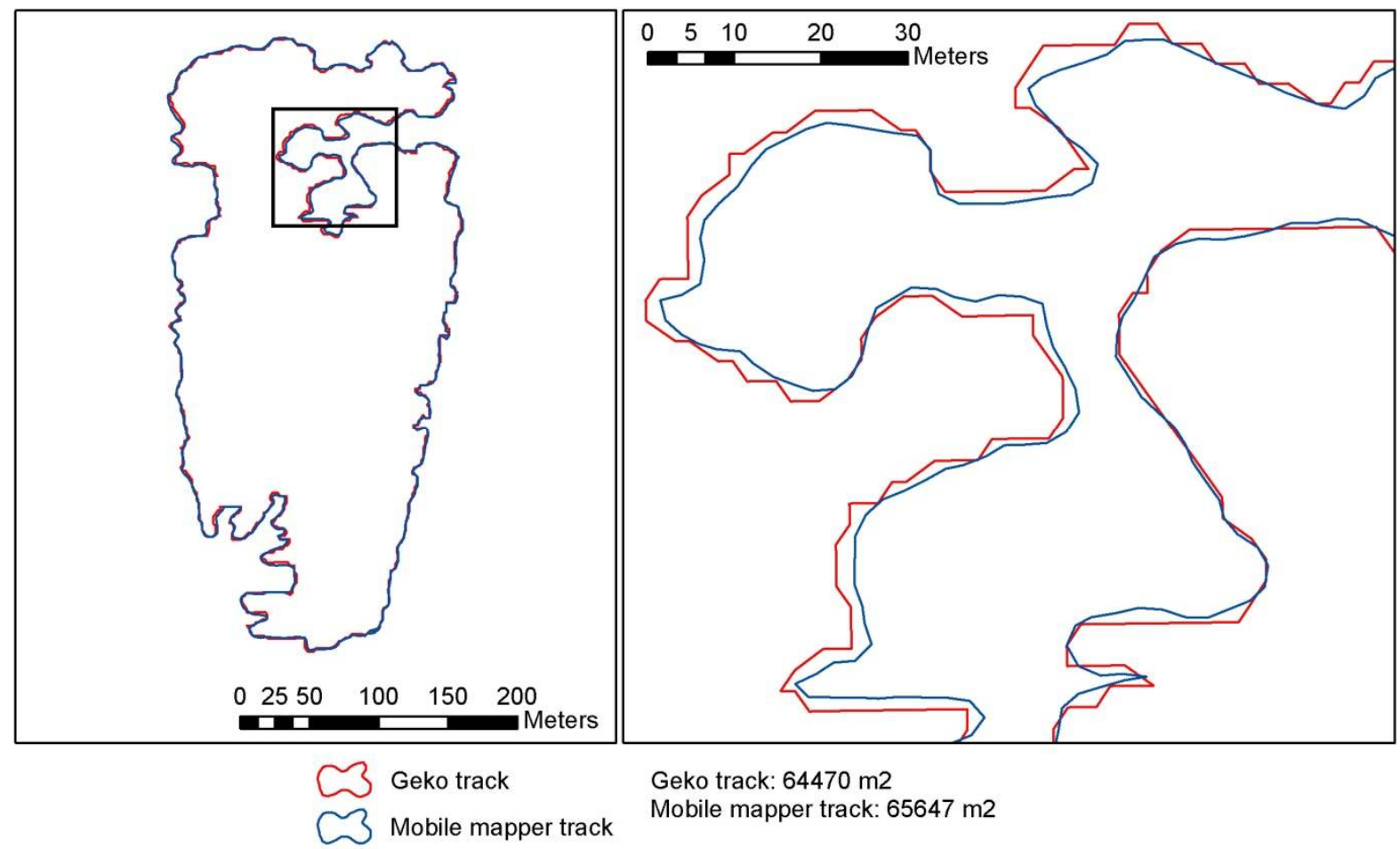

Geko track: $64470 \mathrm{~m} 2$

Mobile mapper track: $65647 \mathrm{~m} 2$

Figure 4.12 Comparison of the Magellan MobileMapper CX and the Garmin Geko 201 GPS tracks

During the measurements, the open water was measured. This excludes soil that is saturated with water. On the CIR aerial photographs, the open water is also much more clearly distinguishable than the saturated soils.

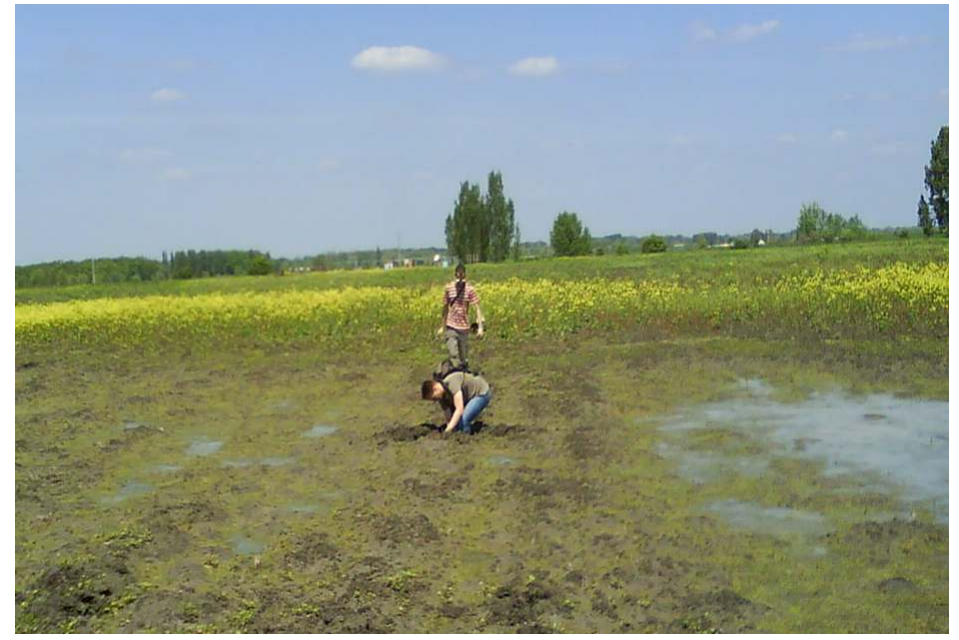

Figure 4.13 In situ measurement of inland excess water (summer 2010)

For the final training of the artificial neural network, a total of 7,8 ha of individual patches from the fieldwork measurements of March 25, 2010 were used, because a lot of inland excess water was measured at that moment and the fieldwork date was the closest to the acquisition date of the CIR images (Fig. 4.14). 


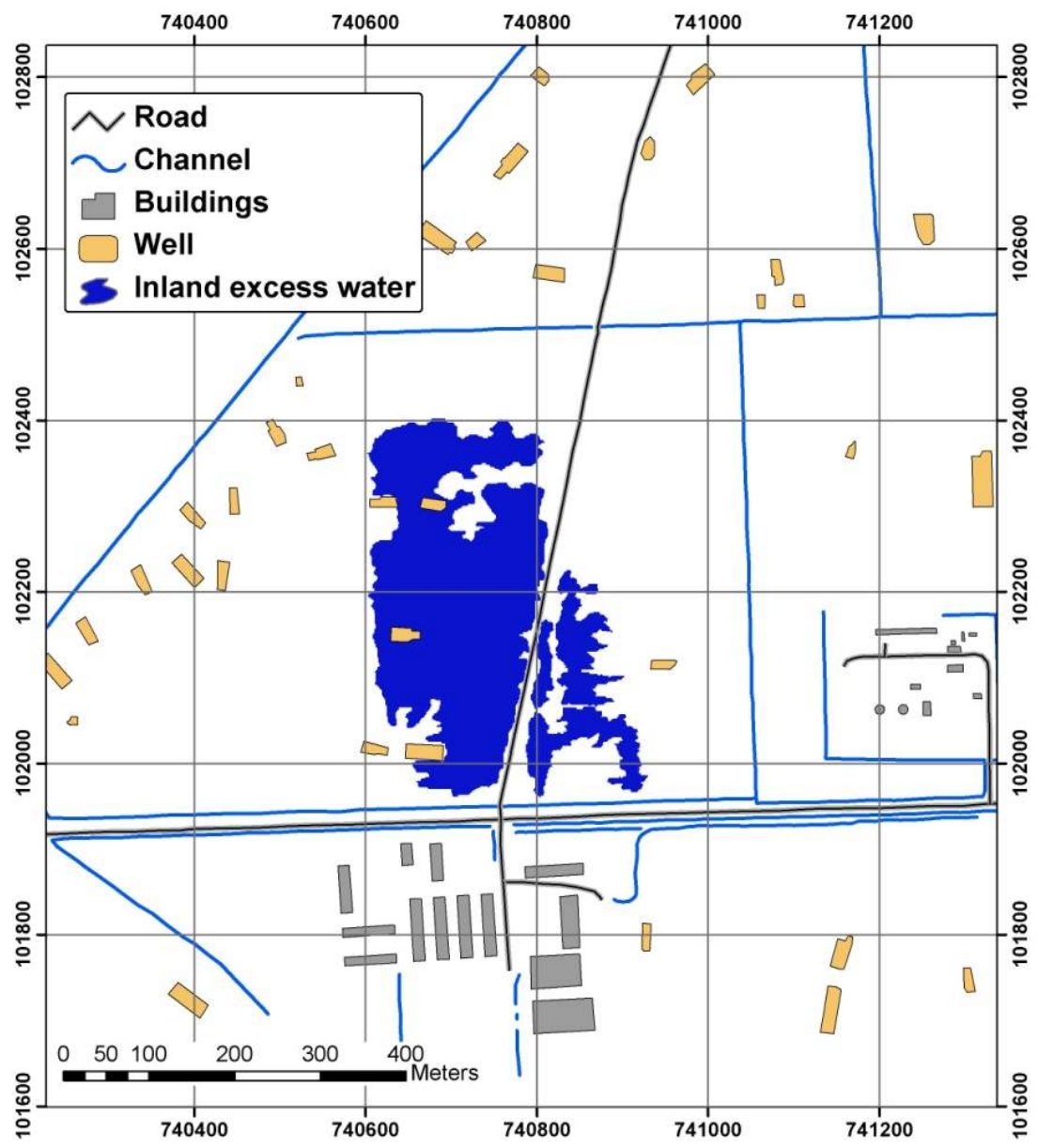

Figure 4.14 Inland excess water fieldwork measurement result map of March 25, 2011

\subsection{Traditional classification techniques}

To evaluate the results of the artificial neural network method, they were compared with inland excess water classification results from traditional parametric statistical approaches. These can be categorized in two groups: unsupervised and supervised classification procedures.

\subsubsection{Unsupervised classification techniques}

Unsupervised classification techniques do not use training data as the basis for classification. They rather aggregate the pixels in a data set to apparent grouping or clusters. The output classes are based on the automatic spectral grouping of the input pixels, and therefore need to be interpreted afterwards to understand what their meaning is in the context of the theme that is being studied.

A common unsupervised classification method is the k-means algorithm. This algorithm starts with a user defined initial number of clusters. The algorithm then creates initial cluster boundaries for these clusters by either generating random feature vectors or by randomly selecting a set of pixels for each cluster from the available data. Each pixel is then associated with its nearest cluster center. Then the location of each cluster center is recalculated based on the pixels belonging to the cluster. This process is repeated until the change of the cluster centers is below a user defined value (Tso \& 
Mather, 2009). A commonly used variant on the k-means algorithm is the Isodata (Iterative SelfOrganizing Data Analysis) algorithm (Tou \& Gonzalez, 1974). In this algorithm - based on the cluster statistics and the distance between cluster means - the number of clusters can change after each iteration (Lillesand et al. 2004). The isodata algorithm was applied to the three CIR bands with a user specified number of classes of 6 (Fig. 4.15).

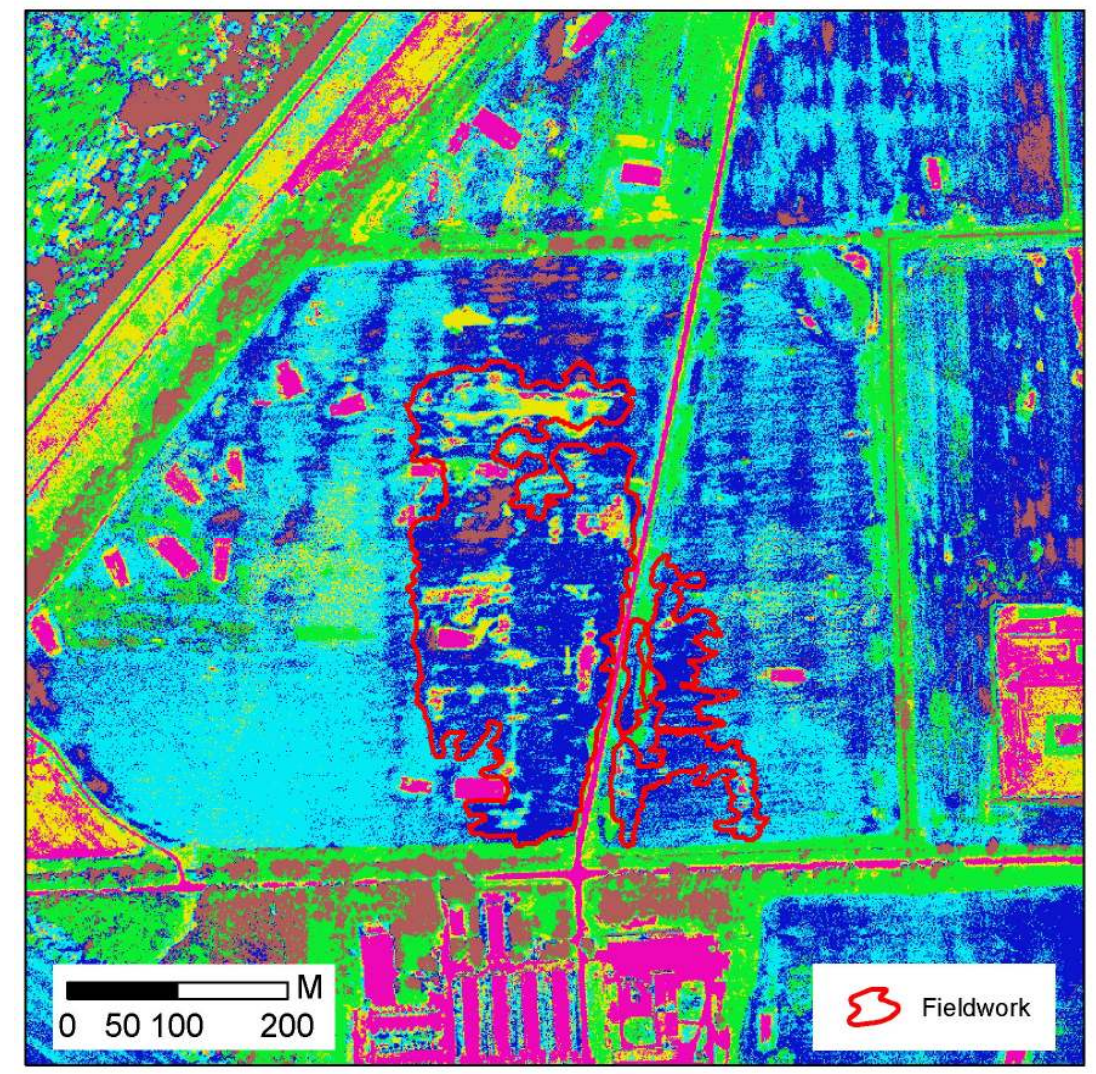

Figure 4.15 Isodata classification result of 6 classes based on three CIR bands

Since the classification is only based on the imagery, the inland excess water training area is not detected. Instead, soil that is covered with water (dark blue) or saturated with water (light blue) is covering all areas that are not classified as building (purple), road (purple), vegetation (green) or other (yellow). The brown colour shows mixed classes like trees, shadows and also water.

\subsubsection{Supervised classification techniques}

Supervised classification techniques use a subset of the data set to define the statistical relationship between the input and output data. From the many available supervised classification techniques, the minimum distance and a maximum likelyhood methods were used to classify inland excess water. These two methods are commonly used to classify land cover based on remotely sensed data. The minimum distance classification technique is a technique where the minimun distance between the pixel and the centers of the classes is calculated either by the Euclidean distance or the Mahalanobis generalized distance. The similarity between objects increases as distance becomes smaller. The mean class center for each class is determined from a training data set. A pixel of unknown identity is labelled by computing the distance between the value of a new, unknown pixel 
and each class center in turn. The label of the closest center is then assigned to the pixel. (Tso \& Mather, 2009). The minimum-distance algorithm is mathematically simple and computationally efficient, but it has certain limits. Most importantly, it is insensitive to different degrees of variance within the defined classes (Lillesand et al. 2004). A pixel can be assigned to a class with a very small variance, at a small distance, while in reality it belongs to a class that has a larger variance, but with a class mean that is further away.

The maximum likelihood classification is a statistical approach where the probability of a pixel belonging to each of the predefined set of classes is calculated, and the pixel is then assigned to the class for which the probability is the highest (Tso \& Mather, 2009). The method assumes a multivariate normal (Gaussian) distribution of the classes in the data set. This assumption of normality is generally reasonable for common spectral response distributions in satellite imagery (Lillesand et al. 2004), but might be difficult to maintain when other data sets are included. Also, the method is computational intensive because the probabilty for every class needs to be calculated.

Both classification methods show problems when classes are aggregated to a higher level. For example, if in an area the class forest is defined, in reality, it may consist of deciduous and coniferous forest. These classes occupy multiple areas in the feature space. In this case, the high level class forest will not show a multivariate Gaussian distribution (Atkinson \& Tatnall 1997).

Minimum distance and maximum likelihood classifications have been executed to compare their results to the ANN classifications. The results are described in chapter 6. 


\section{Development of an integrated geographic information system - artificial neural network framework}

\subsection{Introduction}

To facilitate the efficient application of classification of inland excess water occurrences by artificial neural networks, an integrated GIS - ANN framework was created using a combination of ArcGIS geographic information software, Matlab mathematical modelling software and Python, an open source programming language (van Leeuwen et al. 2008, van Leeuwen et al. 2010).

There are generally three approaches to the integration of GIS and external models (Fig. 5.1). First, loose coupling relies on the transfer of data between the GIS and the external model. With this approach the systems can be both developed and used independently. Tight coupling, on the other hand is usually based in the GIS, from where the external model is called using parameter files. This approach is followed in this research, although all parameterization is performed through customized dialogs in the GIS. The ANN is created and used in Matlab software, but is called via a macro language in ArcGIS. The third type of coupling is the full integration between the GIS and the model (Huang \& Jiang 2002). The full coupling between a GIS and an ANN network is rare (Coleman 2008, Sárközy 1998). According to the knowledge of the author, currently three GIS software exist that employ such a fully integrated GIS - artificial neural network solution; ArcGIS, ENVI and Idrisi. These solutions have been evaluated for use in this research but it was decided not to use them because they employ just one type of artificial neural network architecture, multi-layer perceptrons or a radial basis function network respectively, and they do not offer integrated tools for the evaluation of the training and simulation results.

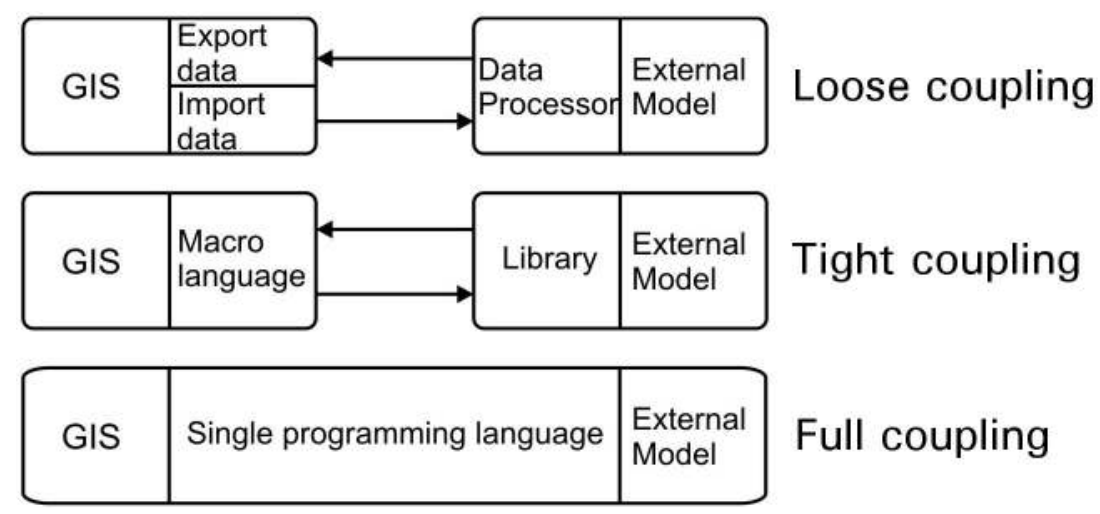

Figure 5.1 Different approaches to coupling (based on Huang \& Jiang 2002)

Mathwork's Matlab 7.10.0 (R2010a) was selected as the mathematical modelling environment. MATLAB stands for "Matrix Laboratory" and is an interactive, matrix-based system and fourthgeneration programming language. It is a commercial software package developed by The MathWorks, Inc. The software has an integrated Neural Network Toolbox that ranges from simple 
solutions to extended neural network implementations (Demuth et al. 2010). It also has many tools for the evaluation of training and simulation results.

Since it was not exactly known what type of neural network with which settings was most appropriate to study the inland excess water problem, and the determination of the network architecture is one of the major and most difficult tasks in the use of artificial neural networks (Barsi 1997, Jafar et al. 2010), it was decided to build a framework to be able to experiment with different neural networks and settings in a GIS environment.

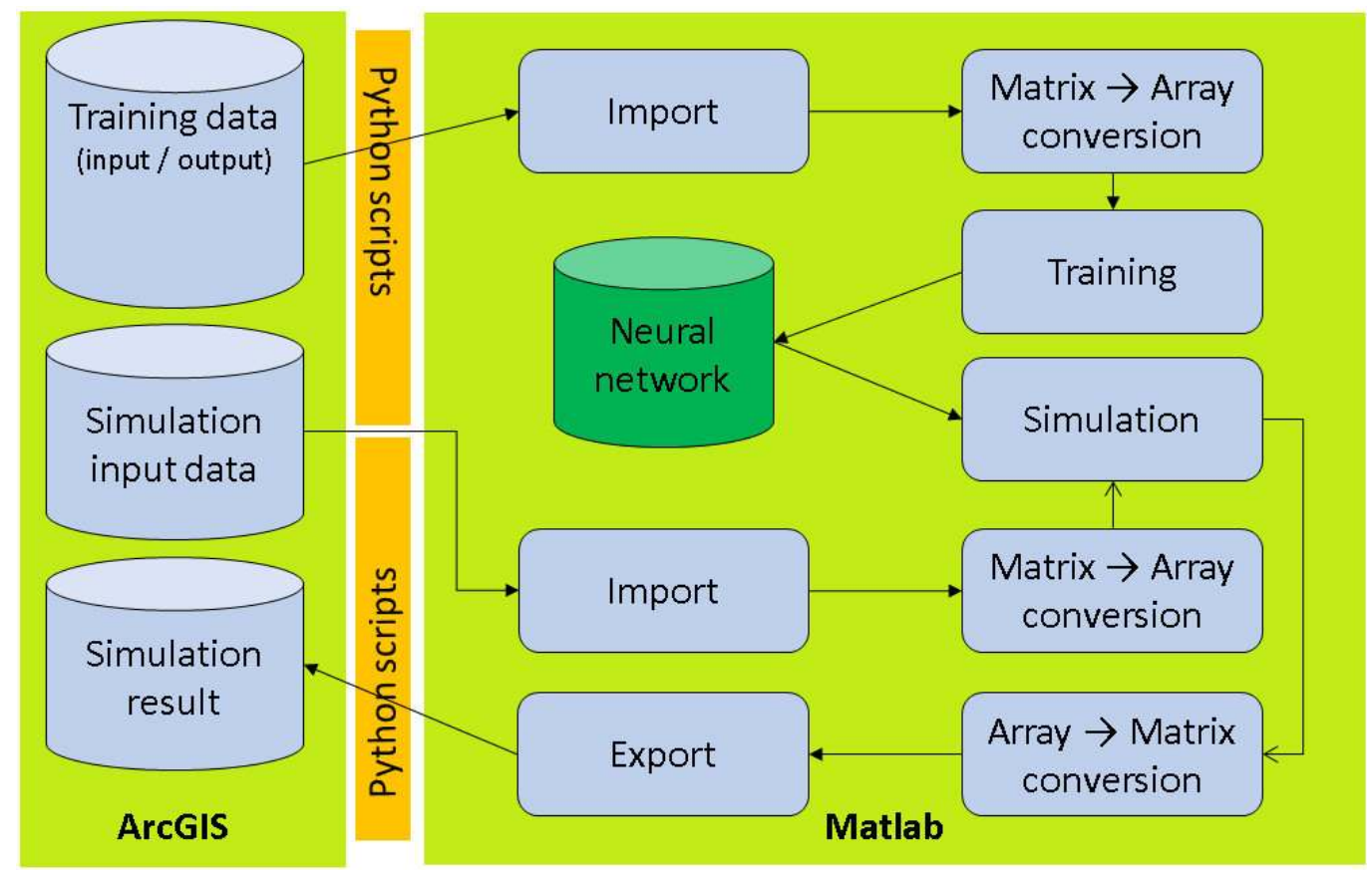

Figure 5.2 ANN - GIS Framework showing the workflow in ArcGIS and Matlab. The steps are discussed in detail in $\S 5.3,5.4$ and 5.5

ArcGIS 10 was used as the GIS environment because of its strong capabilities for geographic analysis, its powerful visualization capabilities, and its possibilities for customization including building user defined geoprocessing scripts that allow for calling other programs. The framework was created to handle input data, intermediate results and output data in a flexible way in both ArcGIS and Matlab. In this way, it was possible to create the data files, test different network settings, perform training and simulation, and evaluate and visualize the training and simulation results efficiently (Fig. 5.2).

\subsection{Neural network settings and input data selection}

A framework has been created that in principle facilitates the use of all available networks and settings of the Matlab Neural Network Toolbox (Demuth et al 2010). The basic network that has been used though is the feed forward neural network with backpropagation with one input layer, one hidden layer and one output layer. The input layer consisted of maximum 9 elements corresponding with the green, red and near infrared band of the CIR images, the classified local 
depressions, the distances to the nearest channel, road, oil well or building and the soil type. In most cases, the neural networks were defined with one output layer describing where inland excess water occurs and where it does not. On one occasion, a network was defined with two output nodes, defining areas with open water, and areas with saturated soil. Experiments have been executed with the amount of neurons in the hidden layer. The minimum amounts that was used was 8 , the maximum was 30. The quality of the simulations was evaluated as well as the performance. Also experiments were executed with the number of input layers. These were varying between 3 and 9, but this number can easily be extended based on the application and data availability.

Matlab's newfit function was used to create new feed-forward backpropagation network. This function uses the Nguyen-Widrow algorithm to initialize the weights of the neurons (Demuth et al. 2010). The algorithm results in a certain degree of randomness in the weight initialization, so they are not each time the same. The initialization that resulted in the best training mean square error (MSE) was selected to be used in the simulation phase.

In general, the Levenberg-Marquardt training algorithm was used, but some experiments were executed with other algorithms. Although often slower, they did not give better results, and have therefore not been included in the descriptions of the results in this research. For all presented results, the default log-sigmoid and linear activation functions were used for the hidden and output layers. The learning rate and values for the momentum were kept at default and no experiments have been executed with them.

During the training phase, the input data was split into three parts. $70 \%$ of the data was used in the training set, $15 \%$ of the data was used to test the trained neural network, and to stop when overfitting occurs. $15 \%$ was used as validation data, which is the data set that is used to evaluate the trained data set with new data.

The training used in the Neural Network Toolbox continues until a specific validation goal has been set. This goal can be specified with the net.trainParam.max_fail parameter (Demuth et al. 2010). In this research, it was always set to 6 , meaning that after 6 failures of the validation checkwhen in six sequential iterations the MSE was larger than during the earlier iterations - the training was stopped and the network with the smallest MSE was saved. This method prevents that the network is saved when the error is at a local minimum instead of the global minimum.

Artificial neural networks are capable of processing large amounts of input data and can work with incomplete and noisy data as well (see $\S 3.6$ ). This does not mean that any combination of input data will result in proper training of an ANN. Careful input data selection for ANN analysis is an important prerequisite to get high quality results (Dawson \& Wilby 2001). This prevents excessive computational complexity and calculation times, and erroneously training. Bowden et al. (2005) identified five methods of data selection for water resource ANN modelling. The most commonly used approach is the selection of input data based on a priori knowledge. This method uses knowledge collected in the scientific field that studies the phenomenon to identify which are the 
most important factors that cause the process. In this research, the same approach was used for the input data selection to identify of inland excess water using an ANN.

\subsection{Data preprocessing}

ArcGIS 10 was used to preprocess all data sets for the training and simulation of the ANN (Fig. 5.3). This geographic information system provides tools to process vector as well as raster data and to convert data from one type to another.

To be able to use data in the ANN analysis four prerequisites exist:

- The data should cover exactly the same geographical region. In other words, the number of rows and columns should be the same

- The data should have the same spatial resolution. In other words, the pixels size should be the same

- The data should be in numerical form

- The data should be in TIFF raster format, with a world file specifying the spatial reference

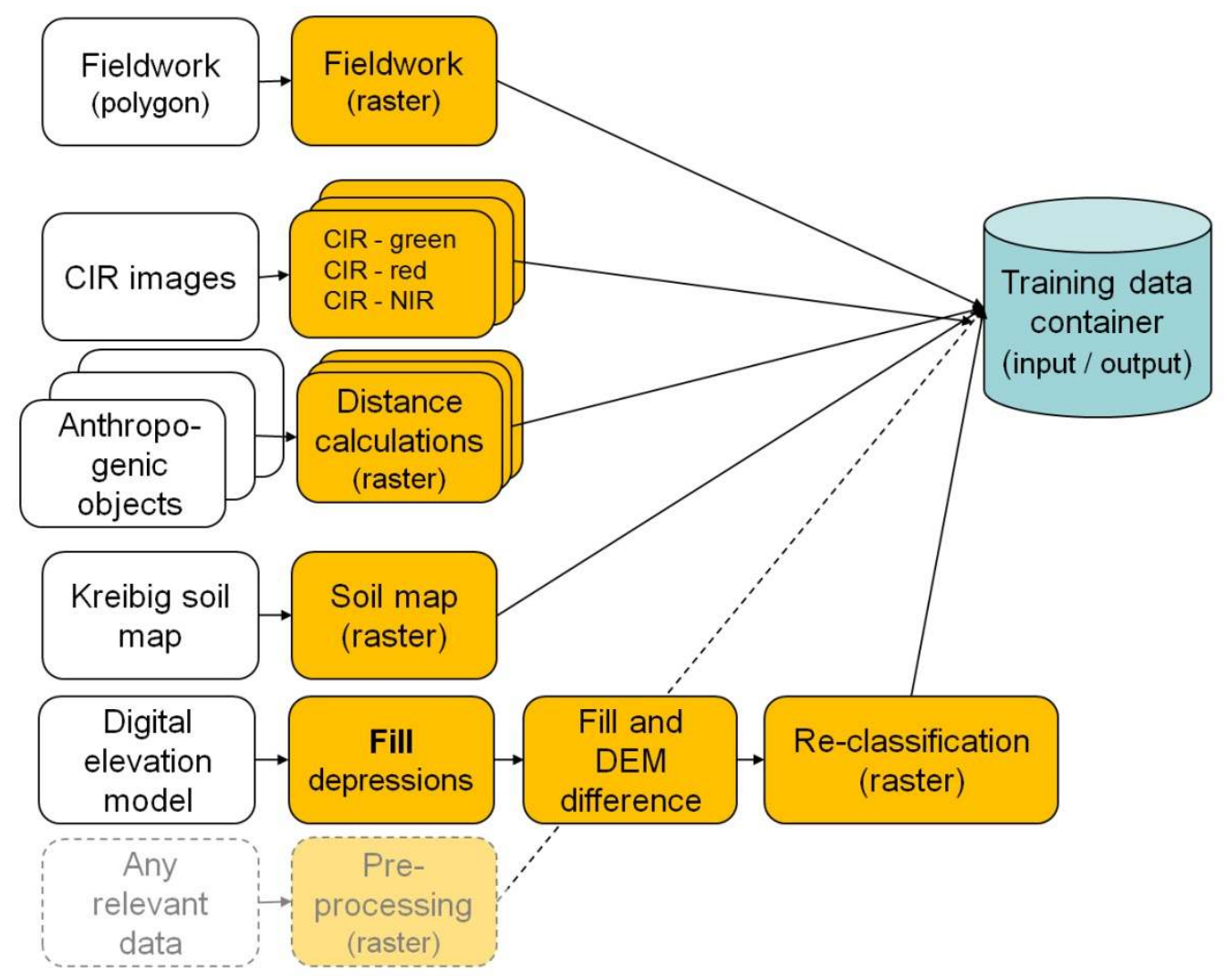

Figure 5.3 The preprocessing of the training data in ArcGIS

Figure 5.3 shows the data sets that have been processed for the ANN calculations. Any data that complies with the above prerequisites can be added to the data container and can be used in the calculations. The preprocessing of the base data is described in the next sections. 


\section{Subsetting, resampling and band splitting of the CIR images}

The colour infrared images are three band data sets with a spatial resolution of 0,62 meter. First, subsets of the mosaic were created for both the training and the simulation area. These subsets were resampled to a resolution of 1 meter using the nearest neighbour algorithm. Then, they were processed into separated bands by splitting the original three band composite images into single 1 byte per pixel TIF files storing the green, red and near infrared bands. These data could then directly be used as input data.

\section{Depression calculation from the elevation model}

The original LIDAR based digital elevation model (DEM) with 1 meter spatial resolution stores absolute height measurements with an average vertical accuracy of $15 \mathrm{~cm}$, which by themselves cannot be used as indicators for inland excess water. Obviously, the depressions are the interesting part of the DEM since there the water remains on the land. Using the Fill geoprocessing tool (Tarboton et al. 1991), the local sinks in the DEM were filled. The original height values where then subtracted from the filled map, resulting in a layer with local depressions (Fig. 5.4).

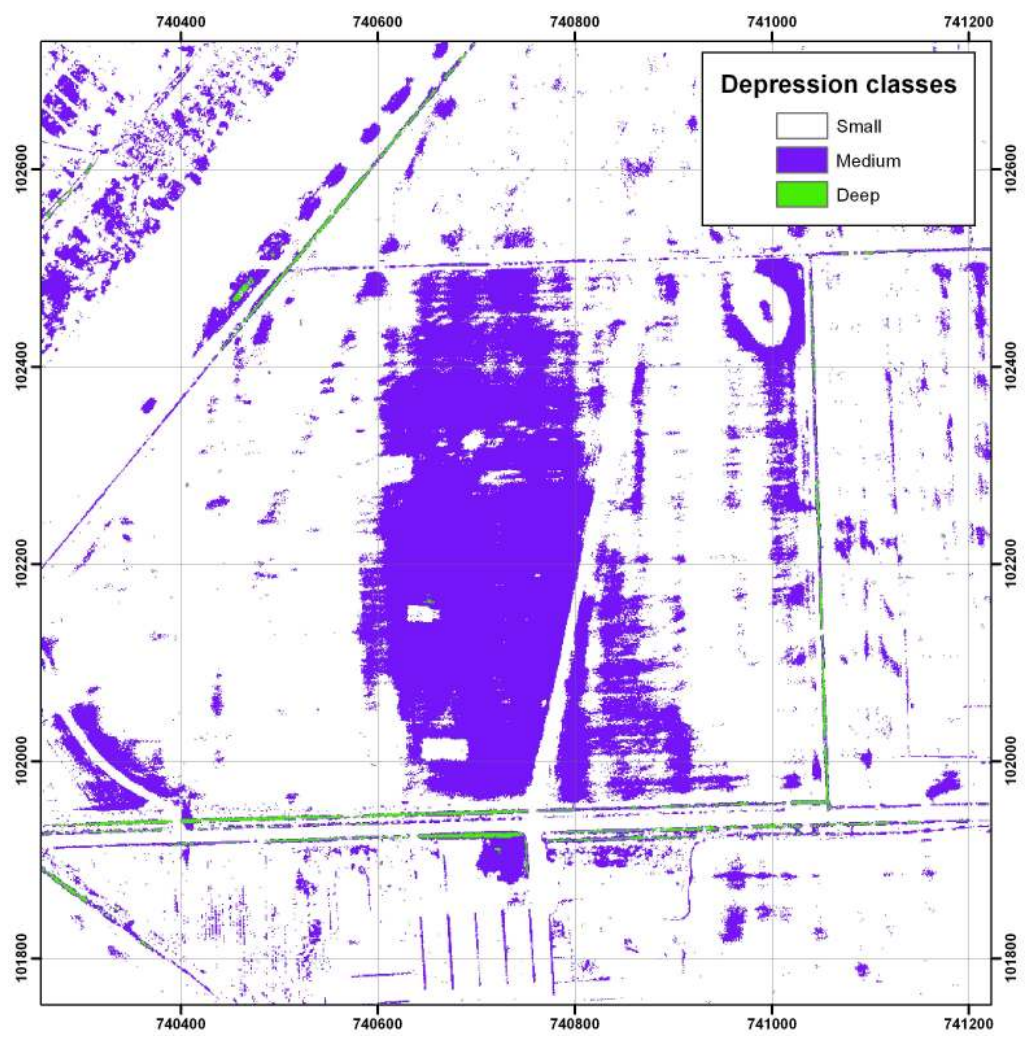

Figure 5.4 Depressions map of the training area derived from the digital elevation model

The depression map was reclassified into three classes: small depressions $(<15 \mathrm{~cm})$, medium $(15-60$ $\mathrm{cm})$ and deep $(>60 \mathrm{~cm})$ depressions. These classes are based on the accuracy of the digital elevation model and observations of inland excess water. In the very flat terrain of the study area, areas that are more than 60 centimeter lower than their direct surroundings are ditches, channels and rivers. These should not be considered as inland excess water. The areas with depressions less than 15 
centimeter are part of the uncertainty of the elevation model. They may also be real (or not, due to errors of the DEM), but then they are normally smaller puddles from where water can evaporate in a short period of time. The areas with depressions between 15 and 60 centimeter are considered to be areas where inland excess water formation occurs. The distribution of the three depression classes is given in table 5.1. About one fifth of the training study area has depressions that can be a factor in inland excess water formation.

Table 5.1. Absolute and relative area of the three depression classes in the training study area

\begin{tabular}{|c|c|c|}
\cline { 2 - 3 } \multicolumn{1}{c|}{} & Absolute area $\left(\mathrm{m}^{2}\right)$ & Relative area $(\%)$ \\
\hline Small depressions & 805675 & 81.2 \\
\hline Medium depressions & 180259 & 18.2 \\
\hline Deep depressions & 6000 & 0.6 \\
\hline
\end{tabular}

\section{Georeferencing and conversion of the soil maps}

The original Kreybig data was just a picture without any coordinates information. The map sheets SZEGED and SZEGED-SOUTH were georeferenced using colour infrared digital aerial photographs and the LIDAR DEM to be able to use them together with other geographic data. The Agrotopo data set already had proper coordinates, but was in vector format and needed to be converted to raster TIF files. Figure 5.5 shows the soil maps of the study area.
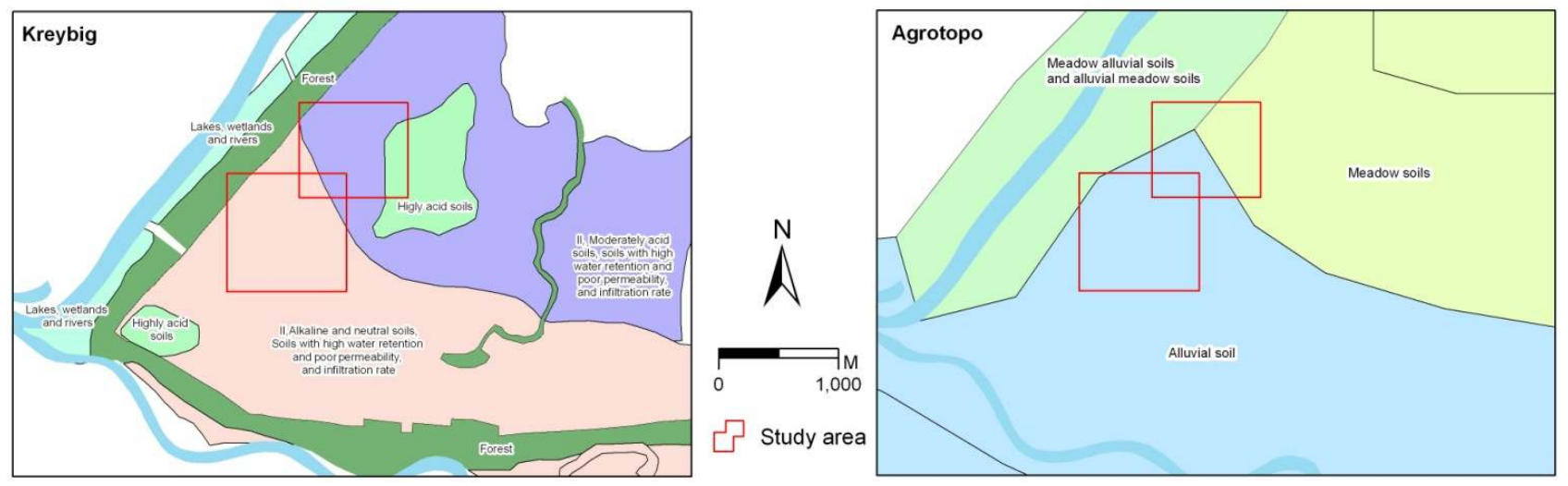

Figure 5.5 The Kreybig soil map (left) and Agrotopo soil map of the training and simulation areas

Although the Kreybig map is more detailed both maps show three different classes in the training and simulation study areas. The water household characteristics of these three classes are very similar. It was decided to use the Kreybig map as a base map, because of the higher detail.

\section{Distance calculations of the anthropogenic objects}

Distance maps were created from the vector maps showing anthropogenic objects using the Path distance geoprocessing tool which calculates, for each cell, the least accumulative cost distance to the nearest source. In the travel cost calculation, only the costs to travel from one cell to another are 
incorporated, no other bias layers were used. The cost to travel from one cell to one of its four directly connected horizontal or vertical neighbours is $1 \mathrm{x}$ the pixel size, while the diagonal travelling cost is calculated by $\sqrt{ } 2 \mathrm{x}$ the pixel size. The resulting map of the distance to channels calculation is shown in figure 5.6. Each distance map was stored as a single 4 byte per pixel file storing the distances as values between 0 and the maximum distance.

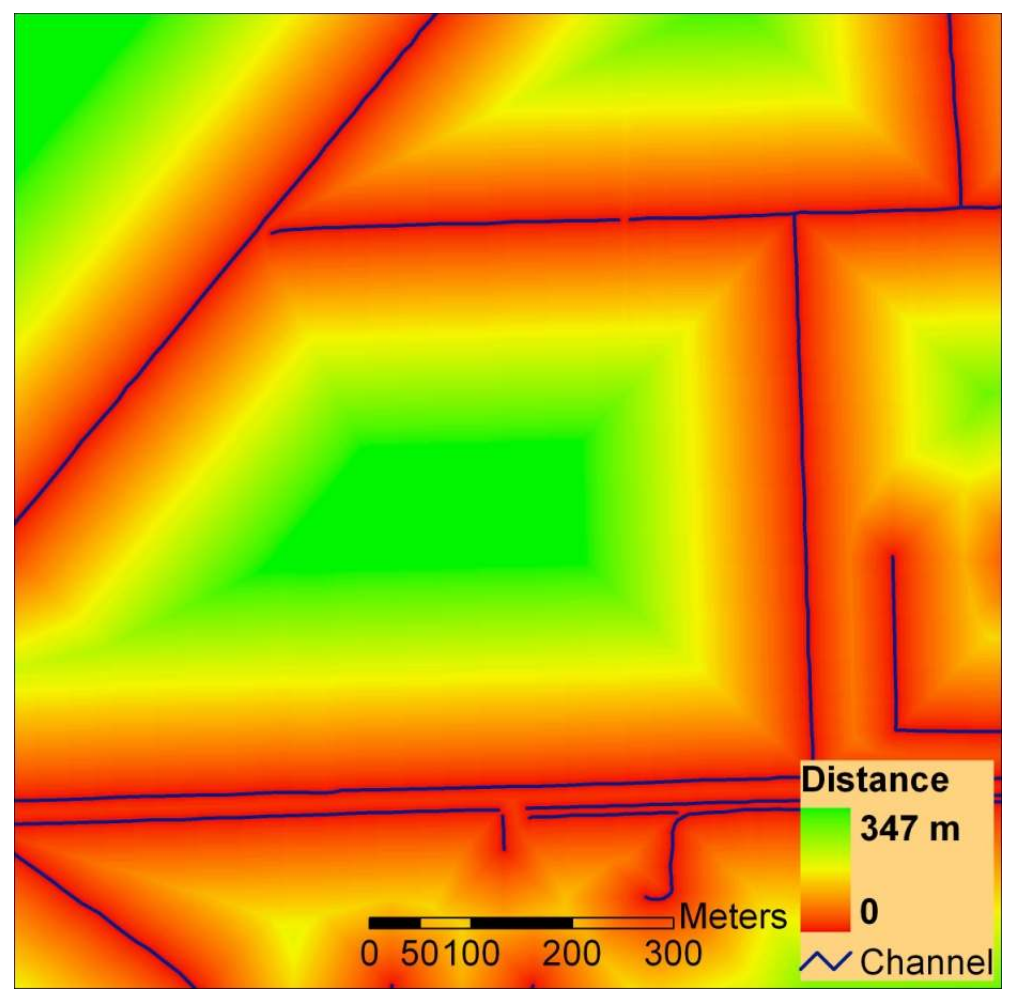

Figure 5.6 Study area with the distances towards the channels

To evaluate the distribution of the distances in the map, a Jenks natural breaks classification was created (Table 5.2).

Table 5.2 Distribution of the distances to channels according to the Jenks classification (Jenks 1967)

\begin{tabular}{|c|c|c|c|}
\cline { 2 - 4 } \multicolumn{1}{c|}{ Class } & Absolute number of pixels / area $\left(\mathrm{m}^{2}\right)$ & Relative area (\%) \\
\hline \multirow{3}{*}{ Distance to channels } & Small $(0-65 \mathrm{~m})$ & 486061 & 49.0 \\
\cline { 2 - 4 } & Mid $(65-151 \mathrm{~m})$ & 339355 & 34.2 \\
\cline { 2 - 4 } & High $(151-348 \mathrm{~m})$ & 166519 & 16.8 \\
\hline
\end{tabular}

\section{Conversion of the fieldwork measurements}

The fieldwork data was collected as track logs, which are lines. The lines were converted to polygons and rasterized with a pixel size of 1 meter to match the other input data. The ratio between inland excess water and no inland excess water is shown in table 5.3. The data is stored as a 1 byte per pixel file storing two values. 
Table 5.3. Absolute and relative amount of inland excess water measured in the training area on March 25, 2010

\begin{tabular}{|c|c|c|c|}
\cline { 2 - 4 } \multicolumn{1}{c|}{} & Class & $\begin{array}{c}\text { Absolute number of } \\
\text { pixels }\end{array}$ & Relative areas (\%) \\
\hline \multirow{3}{*}{ Fieldwork } & Inland excess water & 78562 & 7.9 \\
\cline { 2 - 4 } & $\begin{array}{c}\text { No inland excess } \\
\text { water }\end{array}$ & 913373 & 92.1 \\
\hline
\end{tabular}

When all data is in the correct format, it is stored in one folder. This is the so-called data container. Any data that fulfils the requirements specified before and that is stored in the data container will be used in the neural network training.

\subsection{Training}

In any application of artificial neural networks, the training of the network is the main component. The Neural Network Toolbox is used to define and train the ANN.

\subsubsection{ArcGIS: Definition of the training parameters}

ArcGIS is used to define the parameters of the training phase. For this purpose a custom geoprocessing tool was developed (Fig. 5.7). The upper part of the dialog is used to define the location of the data container and the file between all the files in the data container that is the training output file. This is the file that holds the inland excess water locations. Also the data reduction factor (see $\S 5.6$ ) can be specified here. The lower part of the dialog box is used to define the network and training parameters.
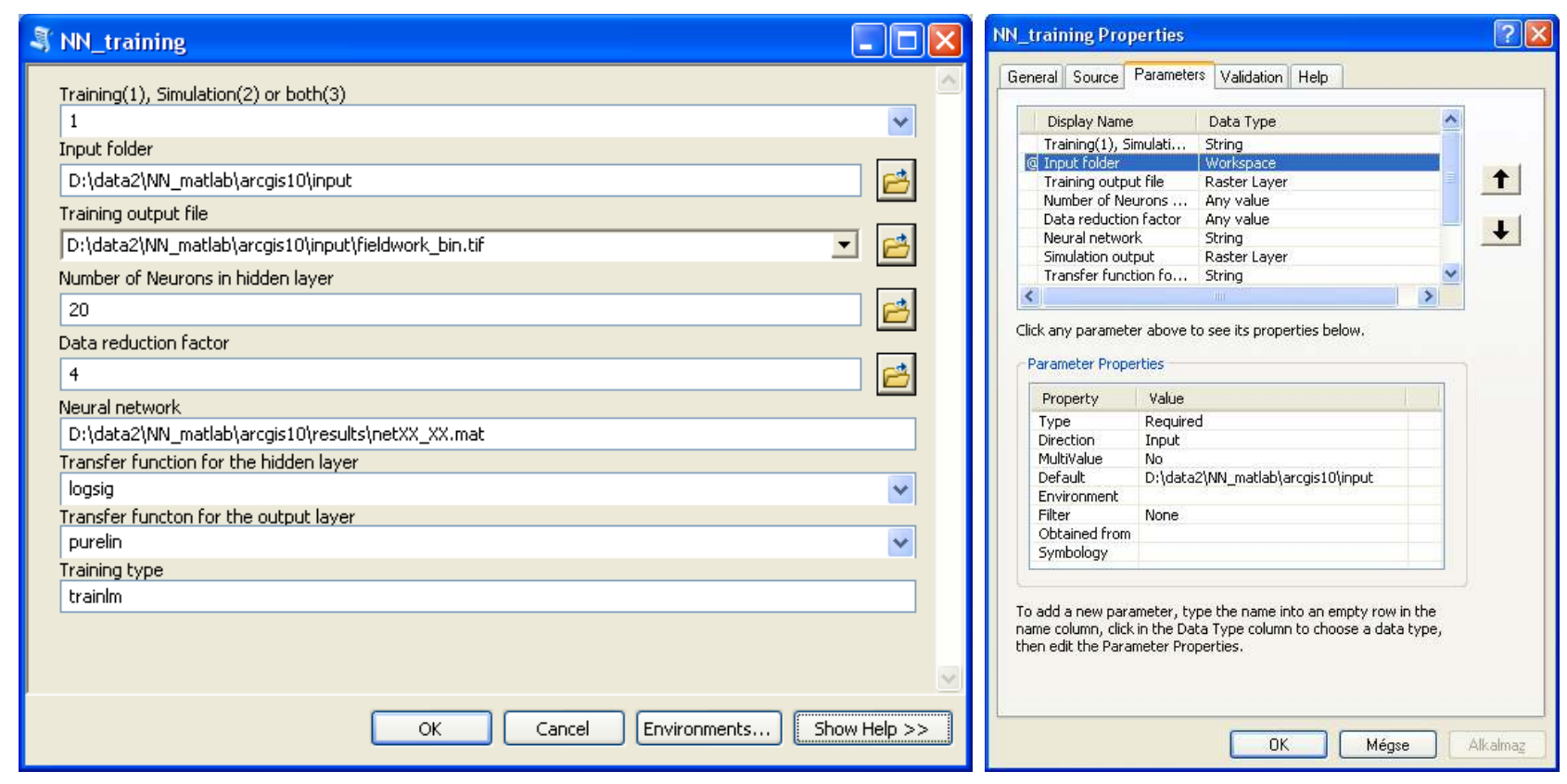

Figure 5.7 Training tool and its parameters (right) in ArcGIS 
Via the geoprocessing tool the name of the network, the type of the network, the transfer functions of the hidden layer and the output layer and the number of neurons in the hidden layer can be specified. Finally, the training type can be set. The dialog sends the different parameters to a Python script. The ArcGIS tool remains open until the neural net is created in Matlab.

\subsubsection{Python: Generation of a command line string for Matlab}

The Python script that is called from the ANN training geoprocessing dialog has a part that creates a command line string for the training procedure and a part that creates a string for the simulation procedure. If the geoprocessing dialog calls for the training procedure only those parameters are used that are required for the training ${ }^{1}$. These parameters are used to generate a DOS syntax that is send to the Windows command line (Fig. 5.8). The syntax calls Matlab in the background, starts the trainnet Matlab script with the training program and feeds the parameters.

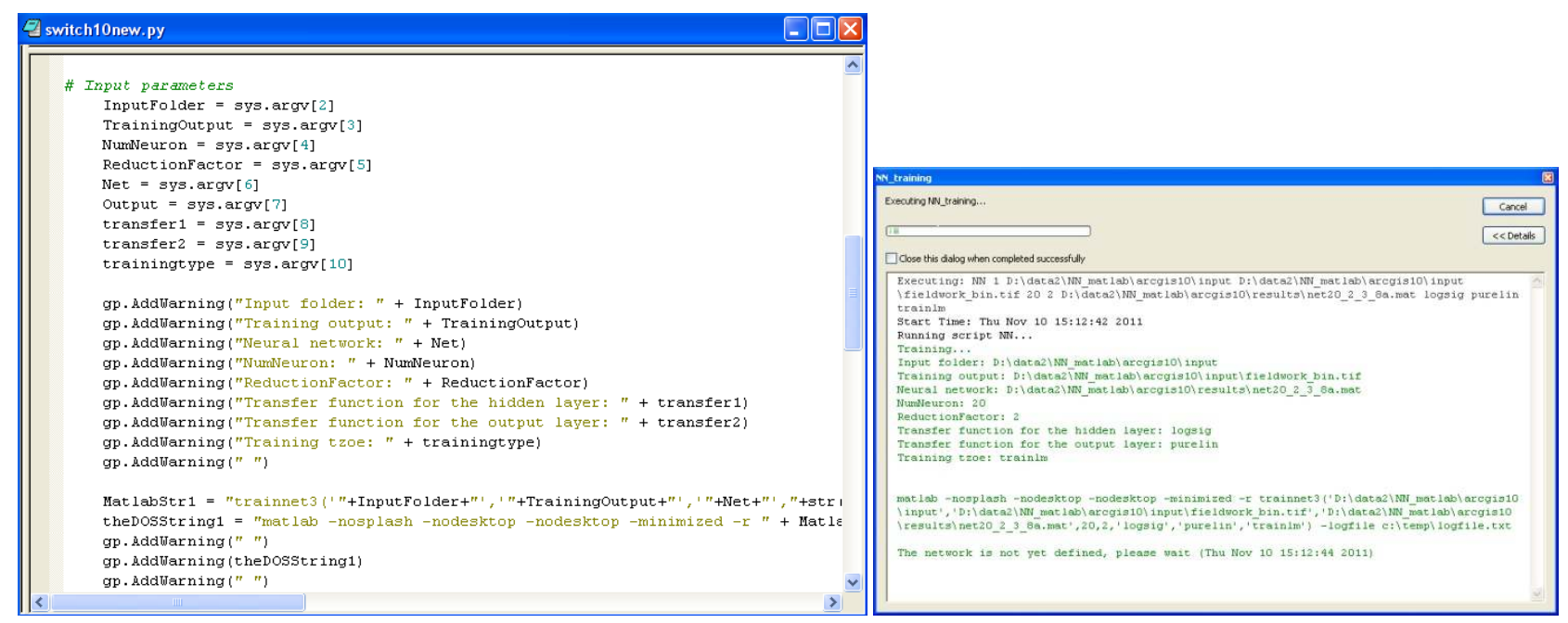

Figure 5.8 The Python training script and the result dialog in ArcGIS

\subsubsection{Matlab: Data conversion and training}

The Neural Network Toolbox needs data in a matrix format where every row represents one data layer, whether this is an input layer or an output layer.

When Matlab starts, automatically the training program is executed (Fig. 5.9). This program is written to convert input files and train to the artificial neural network. First, all $m$ input files are collected. Every input file, except for the training target file is processed in the same way.

\footnotetext{
${ }^{1}$ The programming code that was developed for this research is not published in the dissertation for copyright reasons. The author will provide the code to anybody who may be interested.
} 

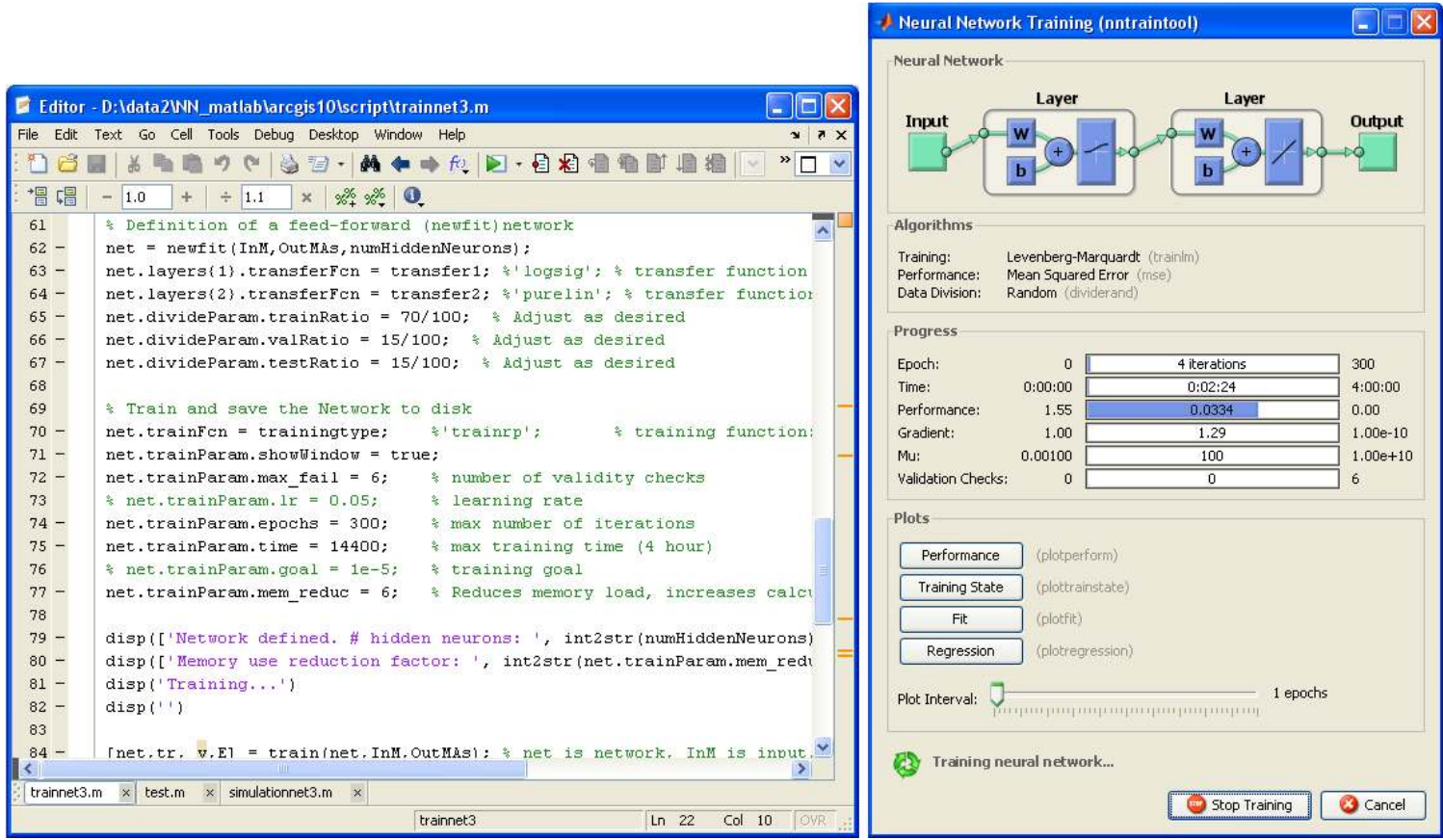

Figure 5.9. The training program in Matlab and the training dialog of the Neural Network Toolbox

The first file (of $i$ rows and $j$ columns) in the data container is converted to an array where the rows of pixels are placed after each other to form a $1 *(i * j)$ array. Then every array is copied into one matrix with $m * i * j$ cells, so the rows are formed by $m$ arrays (Fig. 5.10). If, for example, 5 input images of 1000 rows and 1000 columns are used as input data for the training, this results in an input matrix with $5 \times 1000 \times 1000=5000000$ values. These input matrices grow exponentially in size. To reduce the amount of data during the training phase, a data reduction algorithm was developed (see $\S 5.6)$.

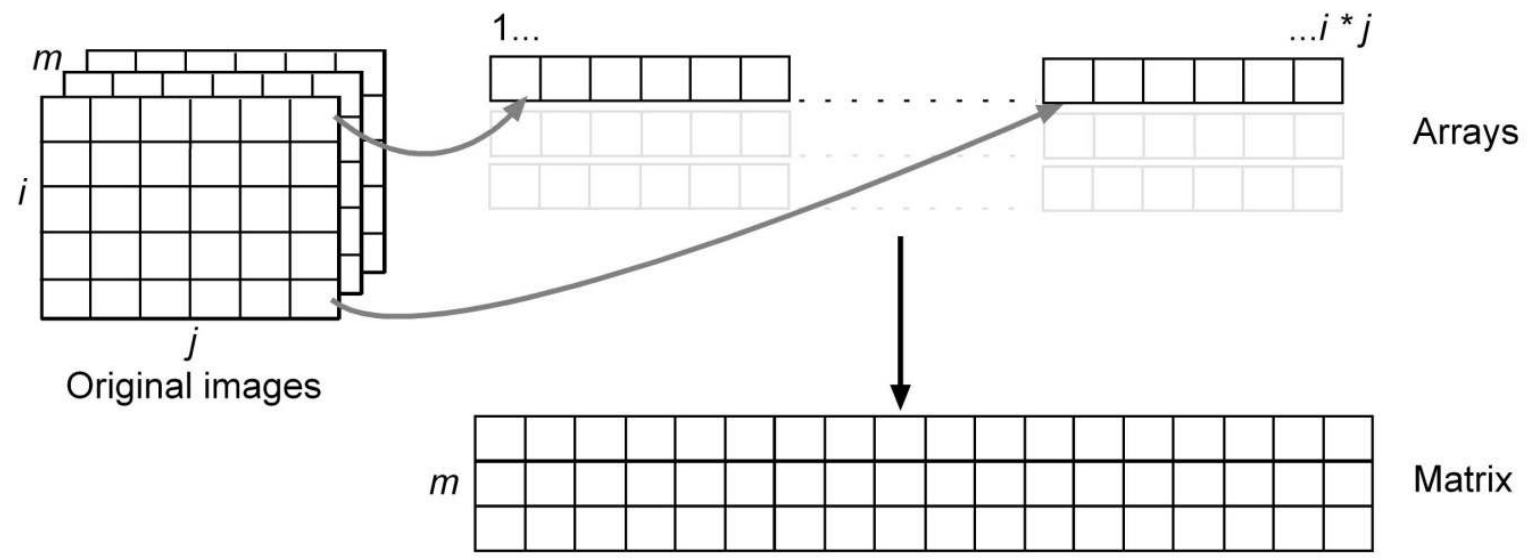

Figure 5.10 Conversion of TIF data, via arrays to a matrix

The output image, which is the fieldwork data showing the occurrences of inland excess water, is converted in a similar way, to a $1 * i * j$ array, and used as the training target.

When the data is converted, the program initializes a new two layer feed forward neural net using the newfit function from Matlab's Neural Network Toolbox. The number of neurons in the 
hidden layer, the transfer functions of the hidden and output layer, and the training method are applied according to the setting specified in ArcGIS. The default training type is the LevenbergMarquardt algorithm (with Matlab's train lm function). Training on the training vectors continues as long as the training reduces the network's error on the validation data. After the network memorizes the training set (at the expense of generalizing more poorly), training is stopped. This technique automatically avoids the problem of over-fitting (Demuth et al 2010). Assuming that the data used to train the network represents the general problem of inland excess water, it can be expected that the accuracy of the network for new data is similar to the accuracy for test data during training. The optimal network is saved with the name specified in ArcGIS and is ready for use in the simulation phase.

\subsection{Simulation}

\subsubsection{ArcGIS: Data preparation}

In ArcGIS, a custom geoprocessing tool was created to specify the input data and set the parameters for the simulation phase of the neural network classification (Fig. 5.11). In the dialog, the input data container, the trained neural network and the output file name of the classified raster map need to be defined. The information in the form is send to a Python script to generate the command line. The tool remains open until the simulation output file is created and sent back from Matlab to ArcGIS.

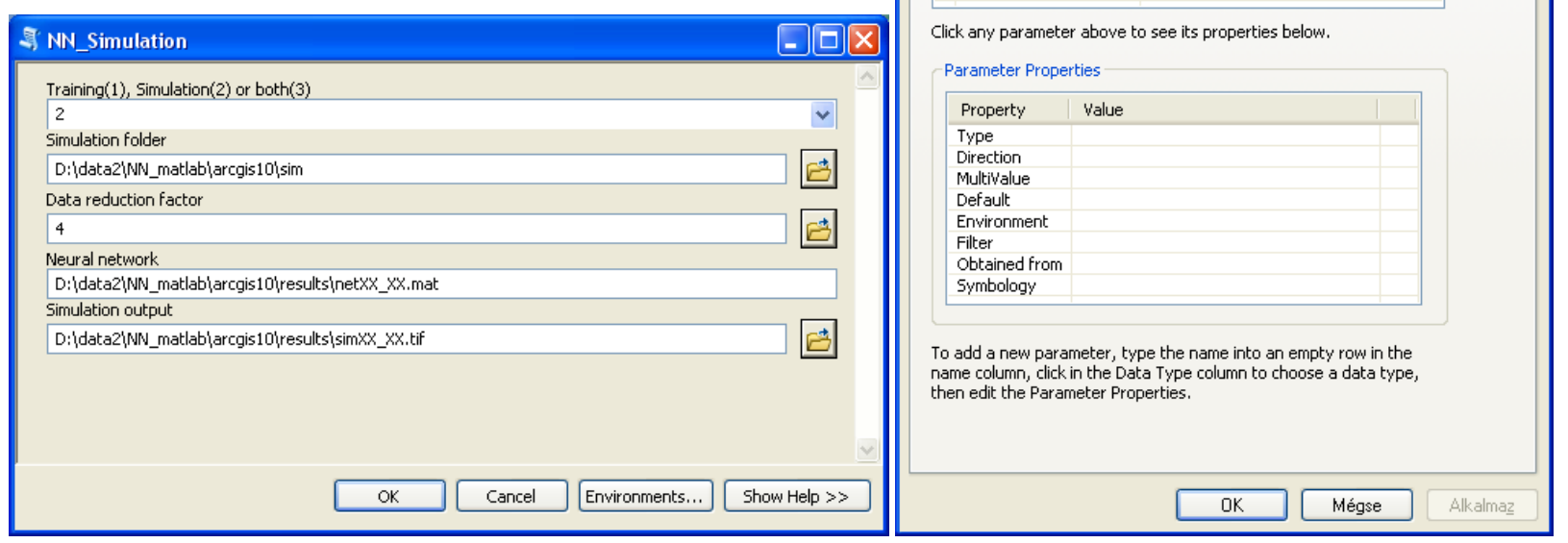

Figure 5.11 The Simulation tool and its parameters (right) in ArcGIS 


\subsubsection{Python: Generation of a command line string for Matlab}

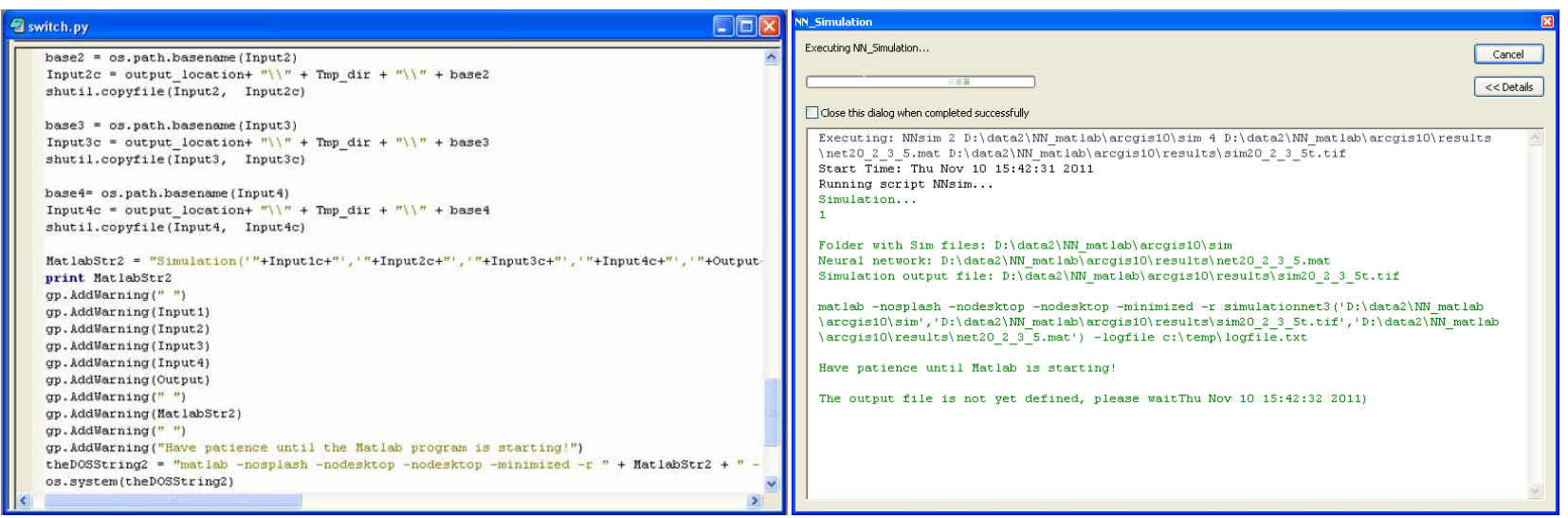

Figure 5.12 The Python script for the simulation phase and the result dialog in ArcGIS

Like in the training phase, a Python script is called from the geoprocessing dialog (Fig. 5.12). The script generates a DOS syntax that is sent to the windows command line to call Matlab in the background and starts the simulation program.

\subsubsection{Matlab: Data conversion and simulation}

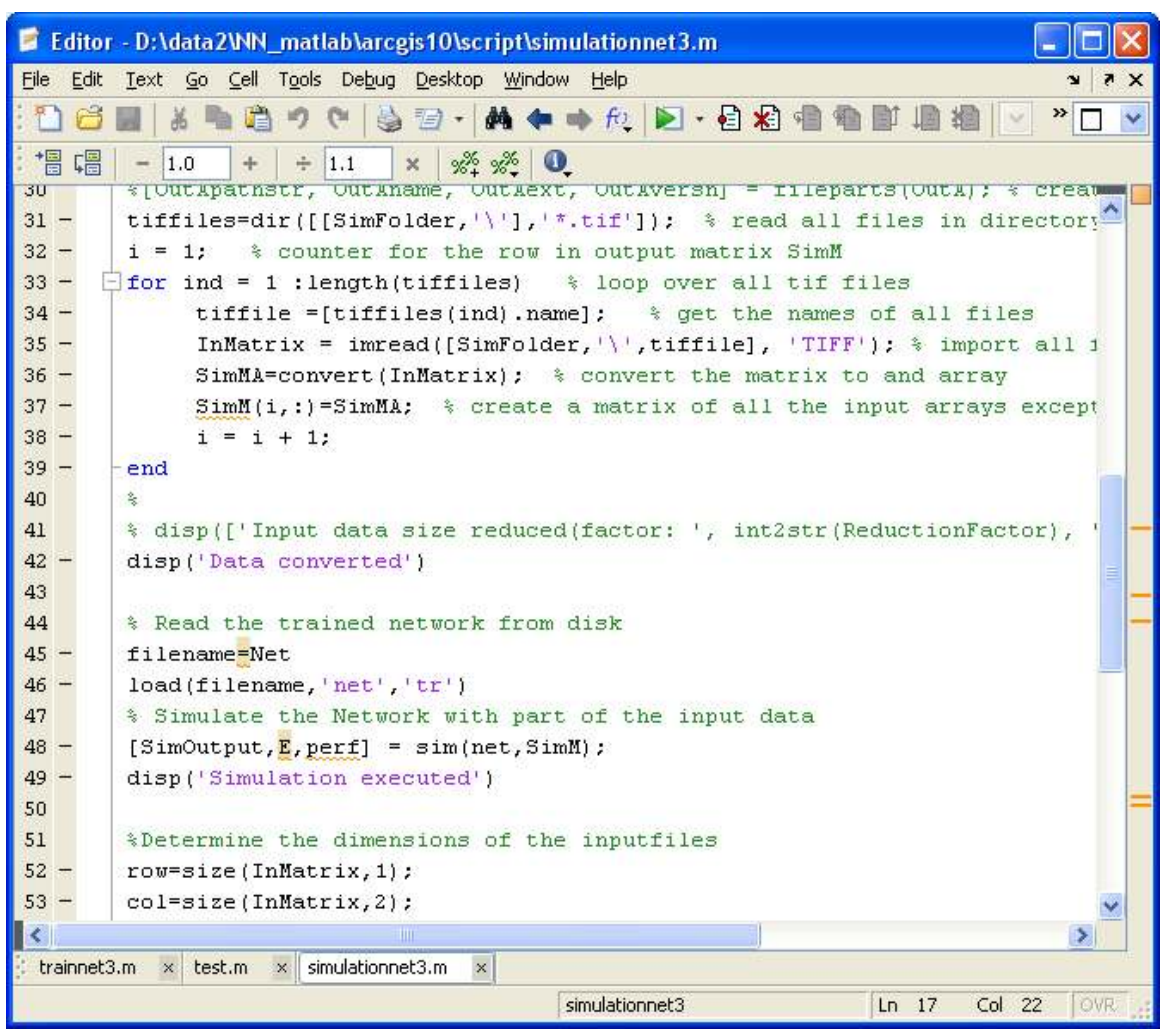

Figure 5.13 The simulation program

When Matlab is started in the background, the simulation m-file is run (Fig. 5.13). This program converts the data layers from ArcGIS generated TIF files to arrays and after that to one input matrix, as described in $\S 5.4 .3$. In this phase, no data reduction is applied; always all data is used in the simulation. This is possible because the simulation phase is merely a multiplication which is not 
very calculation intensive compared to the training phase. The data is fed to the training network and a simulation output matrix is generated. Based on the size (number of rows and columns) of the original input images, the matrix is converted back to a TIF image using the convertback program. The output TIF file is an 8 bit raster map without any georeferencing information. The final step in the script starts a Python script that defines a spatial reference for the output data file.

\subsubsection{Python: Georeferencing of the simulation output data}

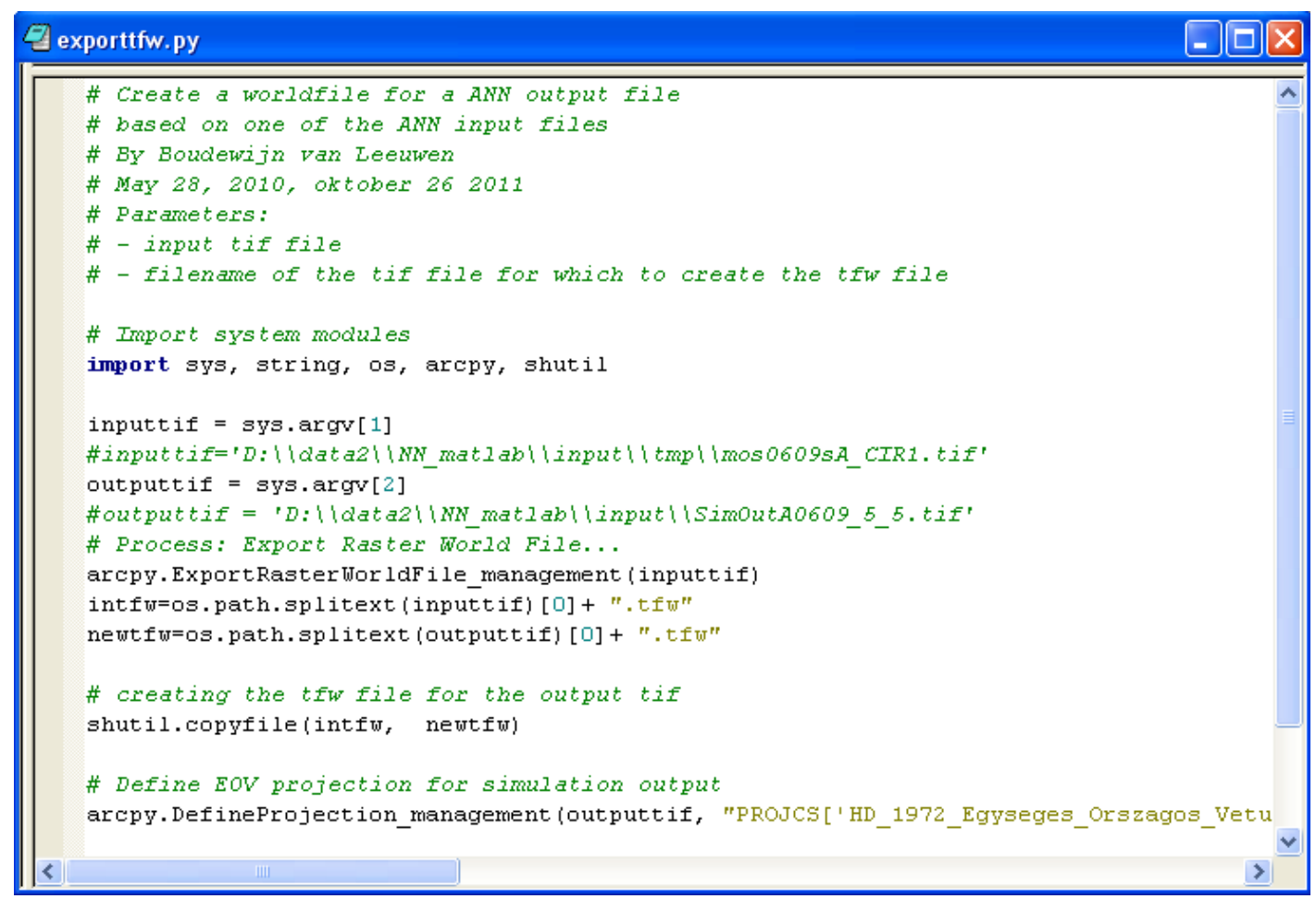

Figure 5.14 Simulation output script

All input files for the simulation phase cover the same geographic area with the same spatial resolution. Based on one of the input TIF files in the data container, a Python script creates a world file that stores the boundary coordinates and the pixel size of the study area (Fig. 5.14). Since the world file gets the same name as the output TIF file, it can be used in ArcGIS to automatically georeference the simulation output image.

\subsubsection{ArcGIS: Visualization and analysis of the simulation results}

The georeference simulation output is opened in ArcGIS where it can be visualized with proper symbolization and analysed together with other data sources (Fig. 5.15). 


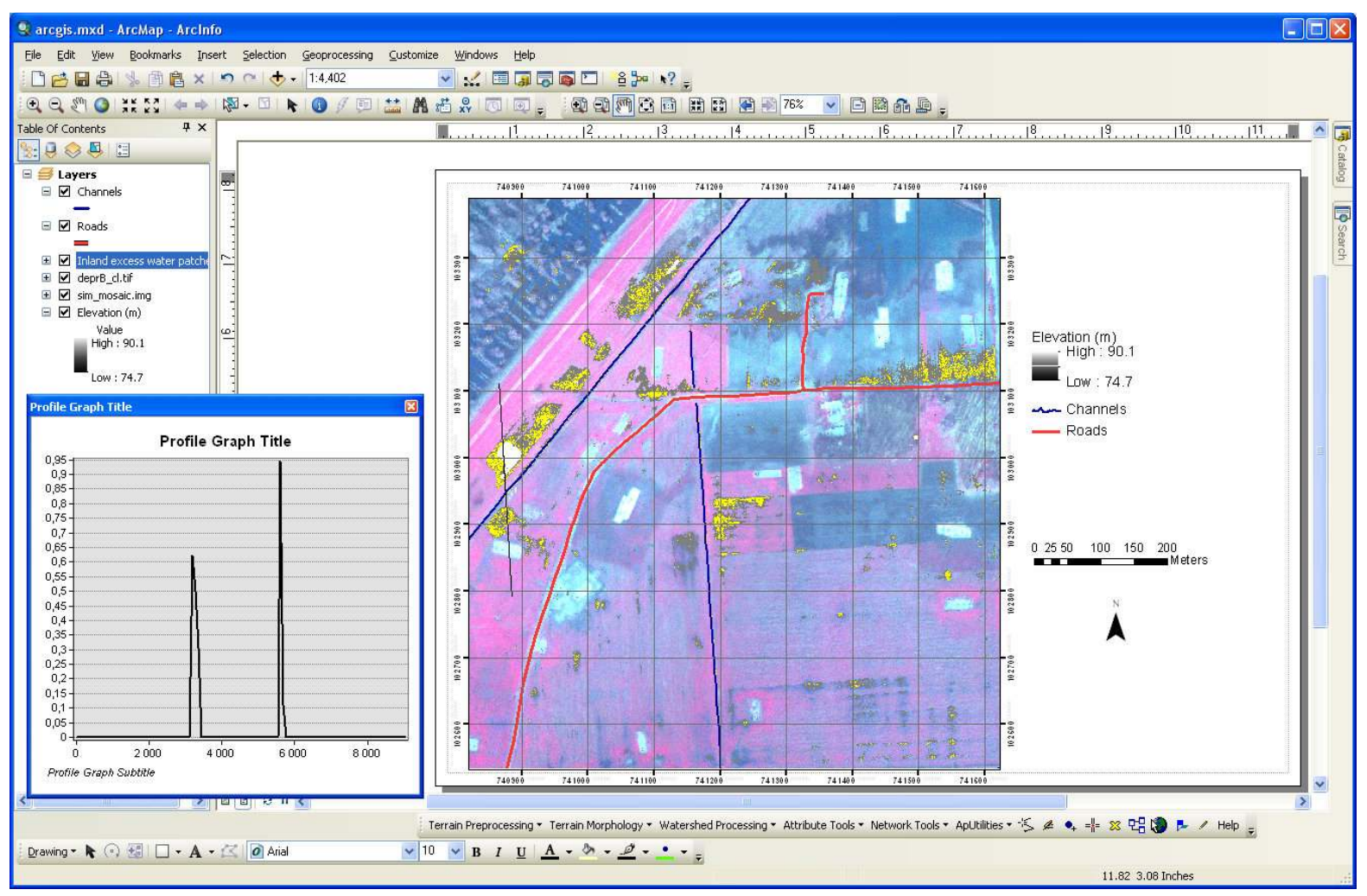

Figure 5.15 Analysis of simulation results in ArcGIS

\subsection{Performance problems}

While developing the framework, performance problems occurred. Due to the nature of artificial neural networks and their training algorithms, the method can be quite calculation intensive. Moreover, in inland excess water analysis, the spatial data consists of many high resolution layers of very large grids. The combination of large data sets and heavy calculation demand resulted in long training times and memory problems.

To overcome these problems, a data reduction factor is introduced during the processing of the training dataset (Fig. 5.16).

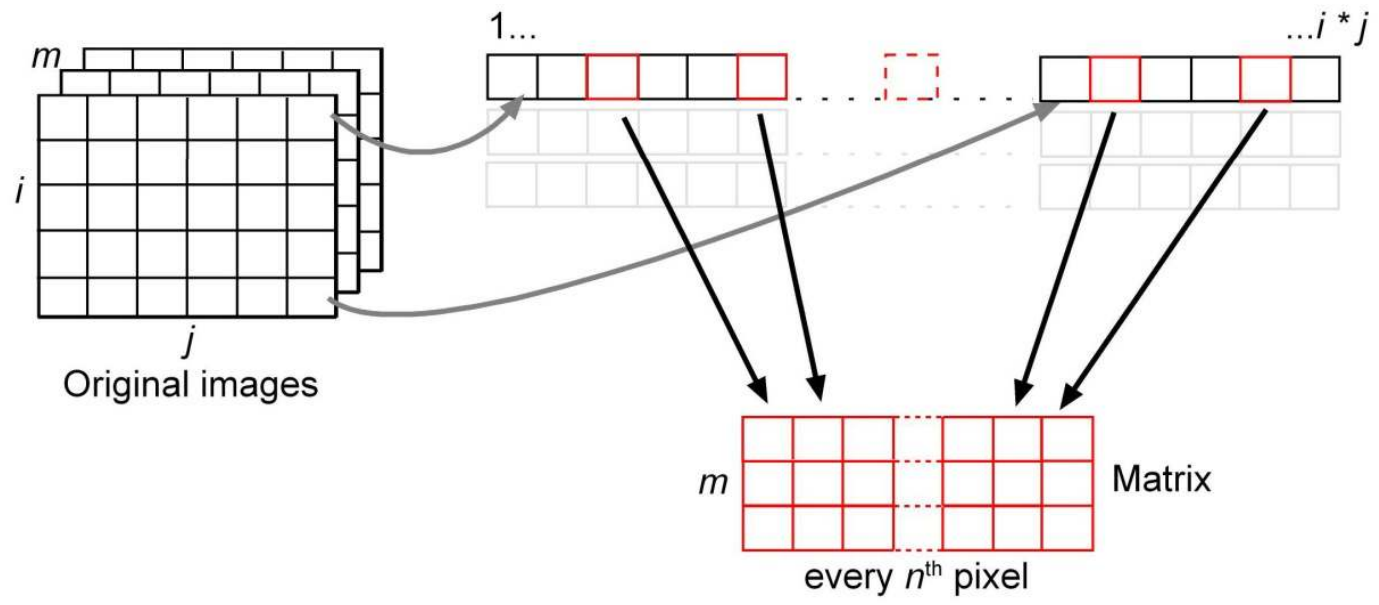

Arrays

Figure 5.16 Data reduction during the training phase 
Instead of taking every single pixel of every input layer into account, only every $\mathrm{n}^{\text {th }}$ pixel is used. After the images have been converted to arrays, every $\mathrm{n}^{\text {th }}$ element is used to create a new and smaller array. These smaller arrays are then combined to the matrix that forms the basis of the training process. The resulting subsets have been statistically tested to verify if they are representative of the original data sets. All tests show that the subsets are representative if the data reduction factor is between 2 and 100 (see Annex 2). Higher data reduction factors have not been tested.

The reduction of the amount of input data in the training process, sharply reduces the training time (see figure 5.17, the individual measurements can be found in Annex 3) and memory load. The use of the data reduction factor has also a positive side effect on the training quality, because the reduced amount of input samples will prevent over-fitting of the network.

Another way to reduce the memory load is a Matlab system function, which was implemented as part of the input parameters of the training dialog in ArcGIS. This net.trainParam.mem_reduc function reduces the memory load, but increased calculation times according to Demuth et al. (2010). During the performance tests it was found though, that with the neural network used in this research, the calculation times reduced when using the memory reduction function (Fig. 5.17, the individual measurements can be found in Annex 3).

The performance tests for both methods were executed with a neural network with 9 input neurons and 20 neurons in the hidden layer. When testing the Data reduction factor the Memory reduction factor remained 3, and when testing the Memory reduction function, the Data reduction factor was fixed at 4 .
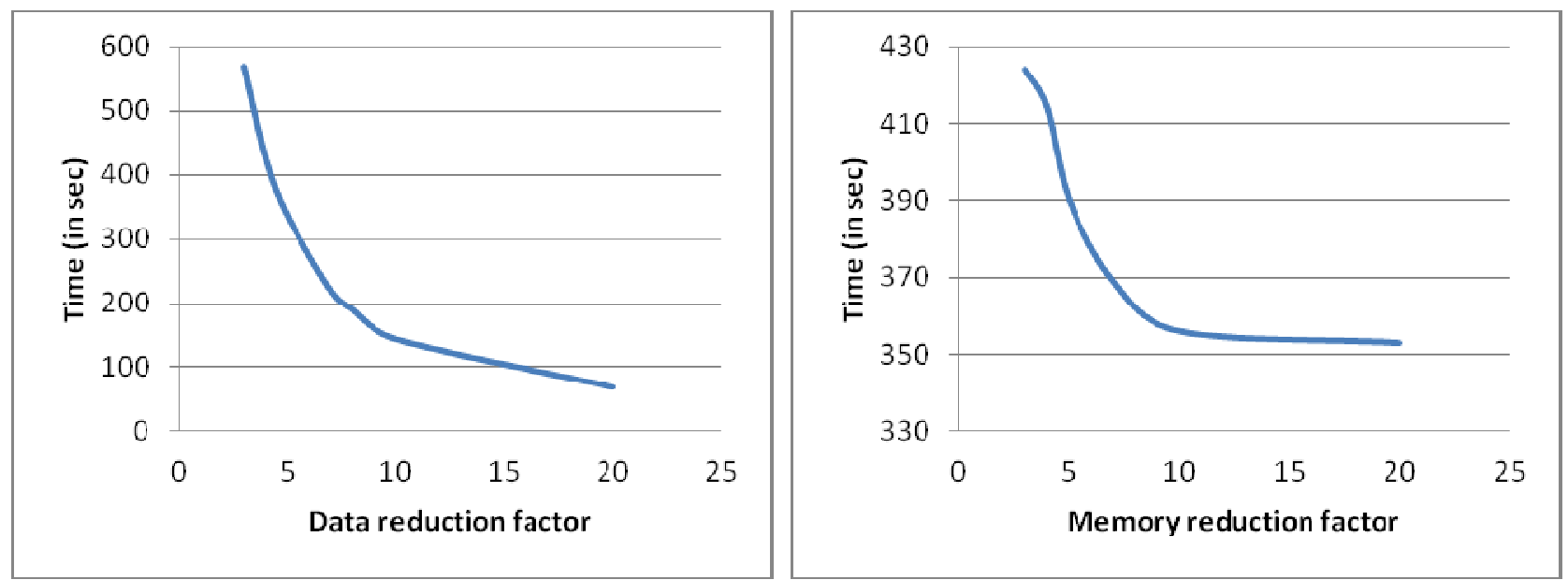

Figure 5.17 The relation between the time needed for 50 iterations during the training phase and Data reduction factor and the training time and the Memory reduction function (on the standard analysis computer with an Intel Core 2 2.6 GHz processor and $2 \mathrm{~Gb}$ RAM)

If the data is not reduced in size, not only performance problems occur, but also out of memory problems arise. During the training phase, on the standard analysis computer an "out of memory" message was given because Matlab reads all data into the working memory (RAM) causing an 
overflow. This problem could only be prevented by using a powerful workstation (Core i5 $2.6 \mathrm{Ghz}$ processor with $4 \mathrm{~Gb}$ RAM), reducing the amount of the input data by reducing the number of input layers, or by using the data and memory reduction methods.

Also during the simulation phase out of memory problems occurred. For example, when the research data set is used (with 1004 x 987 pixels), a matrix is created with almost 1 million elements per row. During the training this matrix can be reduced in size as described above, during the simulation this is not possible, because the simulation is executed on all pixels. In this case, the out of memory problems can only be prevented by using computers with larger internal memory (RAM), or changing the internal functions of the neural network tool of Matlab. These changes include removing error checking which prevents Matlab from duplicating the matrix that is used as input for the network. Internally, this matrix is also duplicated for purposes like reading the minimum and maximum values, and checking for unknown values. These internal functions require optimization to prevent running out of RAM.

The training times are also influenced by the number of neurons in the hidden layer of the network. Figure 5.18 shows the result of a performance test of the number of hidden neurons versus the time it take a network with 20 hidden neurons, 9 input data layers and a data and memory reduction factor of 4 to calculate 50 iterations. It can be seen that the calculation time has a linear relationship with the amount of hidden neurons.

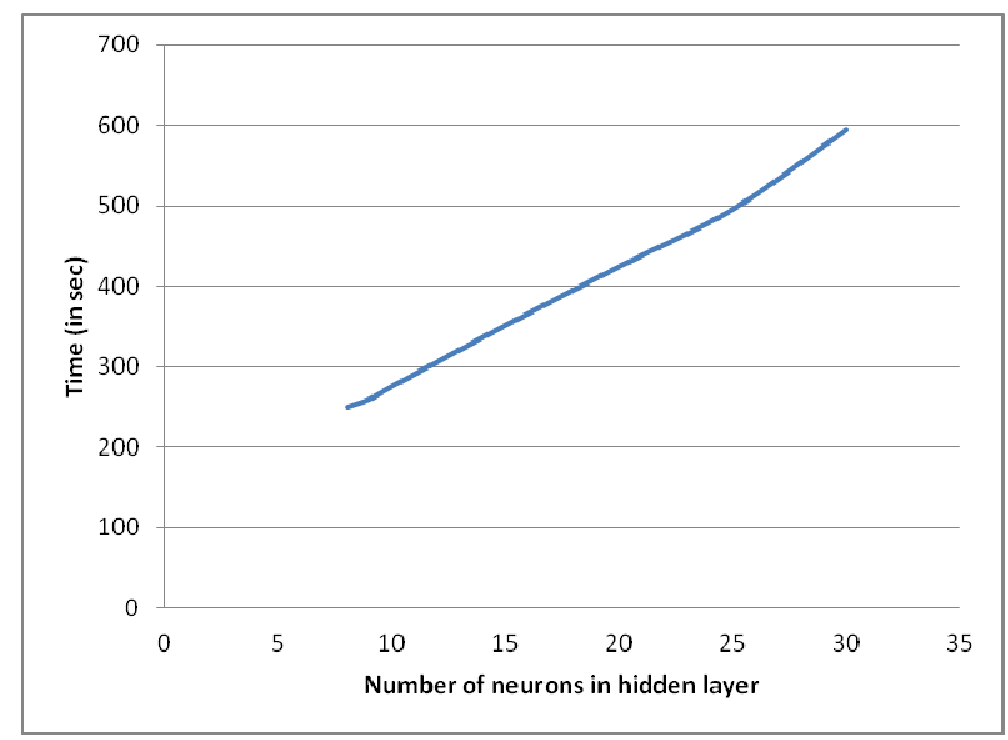

Figure 5.18 The relationship between the amount of neurons in the hidden layer and the training time

Only networks with less than 30 neurons in the hidden layer have been tested, since larger hidden layers did not increase the quality of the simulation results of the network, and do not show a different relationship with the calculation time. Since 9 input layers are used in this performance test, it is not feasible to use small networks, since they will not be able to represent the training data. For the sake of testing, one small network with less than 9 hidden layers was used in the performance test, but this network did not show a different relationship between the two variables. 


\section{Results}

A large variety of trainings and simulations was executed to determine the optimum method of calculation inland excess water in the study area. Experiments were executed to determine the best settings for the neural network, to evaluate the contribution of the individual layers to the solution and to estimate the overall success of the method.

\subsection{Training and simulation results}

Several settings for the amount of neurons in the hidden layer were tested. With an increase of the neurons, the correlation between the simulated output and the expected error decreased, but the performance of the training also decreased sharply (Fig. 5.18). A first experiment was executed with a network with 10 hidden neurons, without using the data reduction algorithms. In total 4 input layers were used: the three bands of the aerial photograph and the classified local depressions map. This resulted in a correlation $\mathrm{R}=0,74$. The result of the training is shown in figure 6.1 (left). The yellow areas were classified as inland excess water, and correspond to the ground truth data (as shown in figure 4.14).
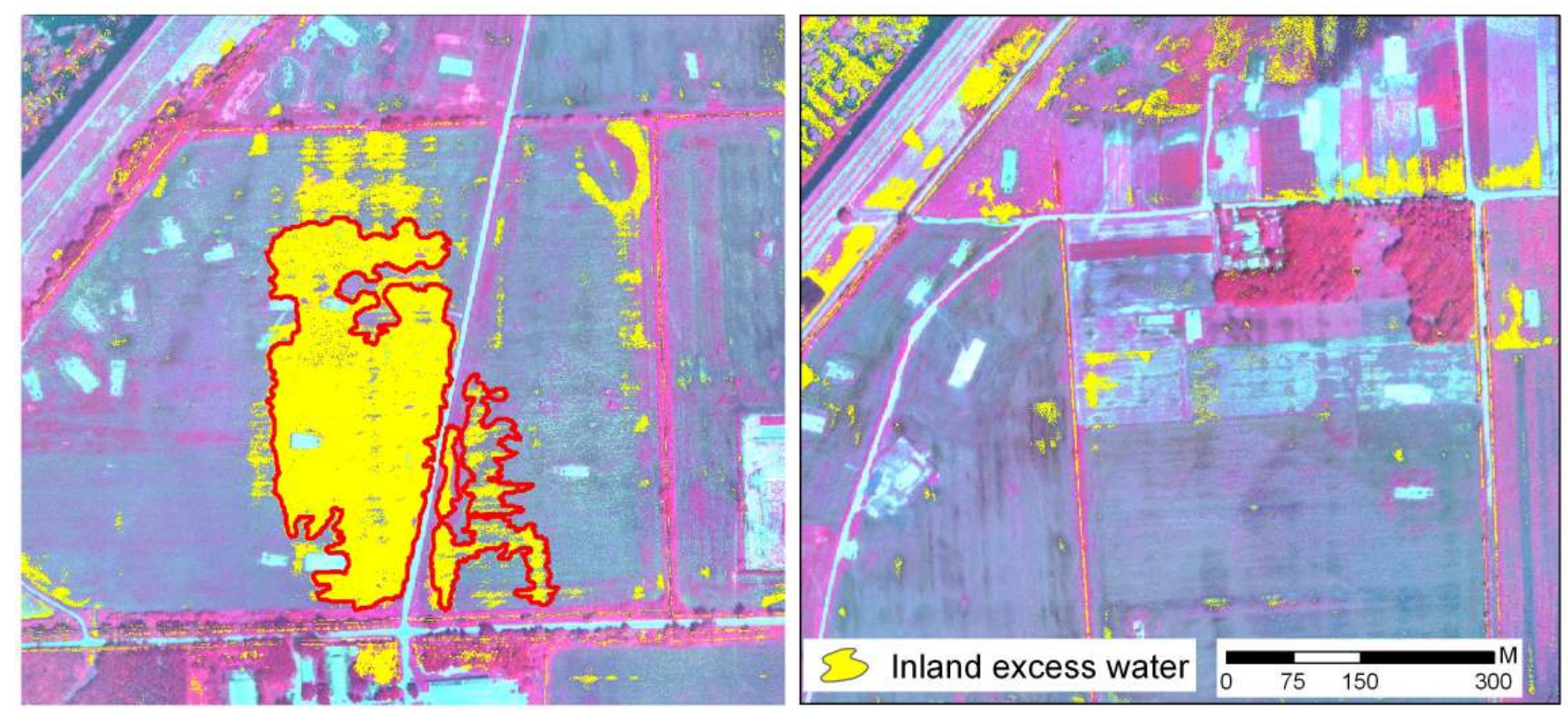

Figure 6.1 The training (left) and simulation (right) results for a network with 10 neurons

Figure 6.1 (right) shows the result of the simulation using the network that was trained with the data in the training area. In the north and northwest part of the area the results are corresponding with the ground truth. The open water along the levee (in the northwest) and the roads (in the northeast) was detected. The inland excess water in the south part of the images is not properly classified. Some pixels are correctly indicated as inland excess water but the majority is classified as dry land. These errors are probably due to the composition of the training set, where only water was incorporated but saturated soil and vegetation in water were omitted. 

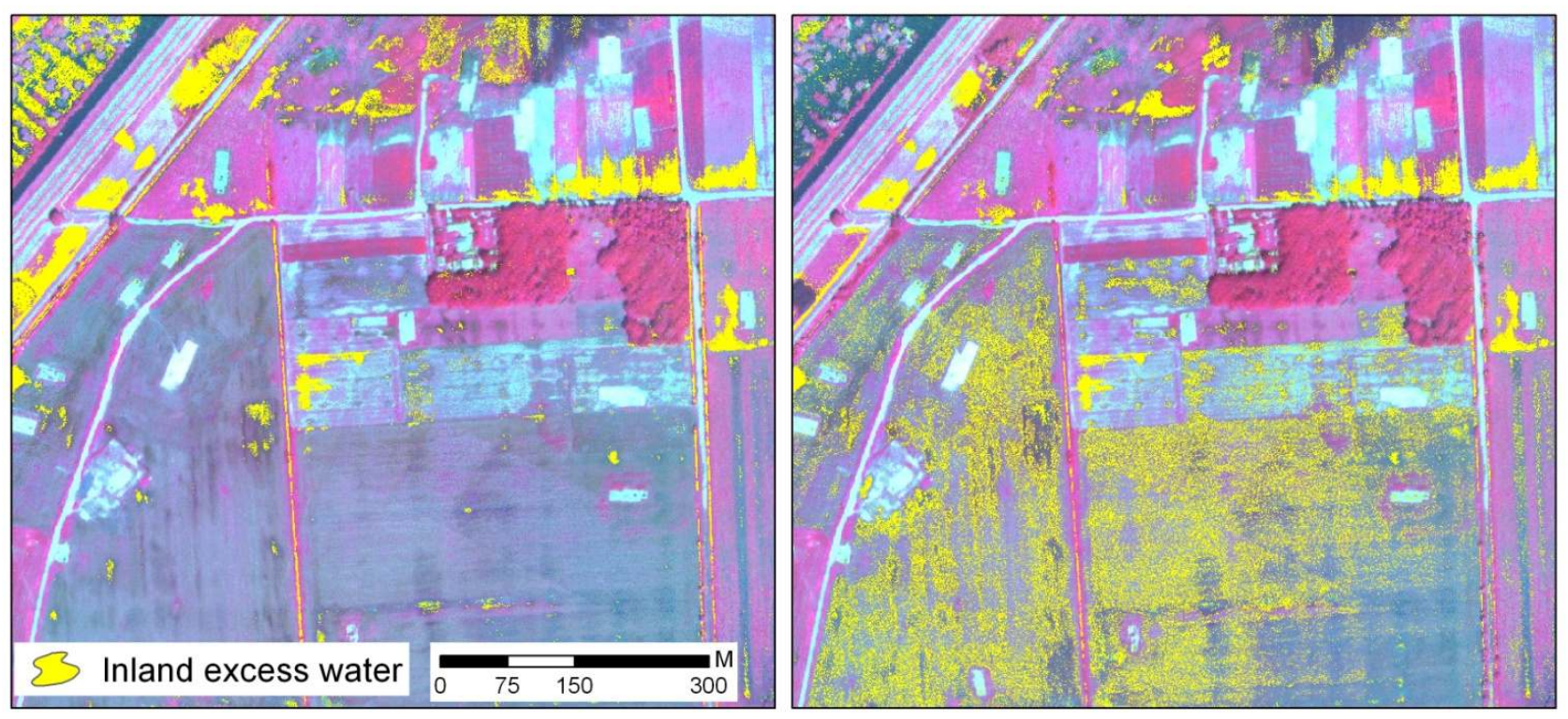

Figure 6.2 The simulation results of two different times: 24 March 2010 and 9 June 2010

A second simulation was executed using the same trained ANN, but this time with multi-spectral data of a different date. In this simulation, the colour infrared images collected on June 9 were combined with the same local depression data that was used in the first simulation (Fig. 6.2).

Although in general, the inland excess water areas that were classified on the March 24 images, were also classified as water on the June 9 images (51\% of the pixels of the larger water bodies is found in both simulations), on the second date much more inland excess water was classified (2.6 ha and 10,8 ha respectively). Also the second simulation shows that there is scattered water on the large parcels in the center of the images. This may indicate that the soil in this area was completely saturated with water. Since no ground truth was collected for the area at the time of the data acquisition, it is not possible to quantify the simulation differences.

During the fieldwork only areas with open water have been accurately measured using GPS devices. In practise, soil may also be completely saturated with water. To test the ANN - GIS framework for this type of situations, a new output map was created showing three classes:

1. Open water, where the water covers the soil

2. Saturated soil, where the water has fully infiltrated the soil

3. Dry soil, where the water via runoff or evapotranspiration has disappeared.

The Open water class was derived from the original accurate fieldwork measurements. The saturated soil was digitized based on visual inspection of the colour infrared images. Figure 6.3 shows the input data symbolized with diagonal lines and the simulated classes in solid colours. Although, the training target cannot be considered to be an accurate representation of reality, visual inspection of the result does indicate that the framework can also detect other inland excess water classes, if it was fed with proper training data. The simulation was performed with a feed forward network with 20 hidden neurons and 9 input layers. 


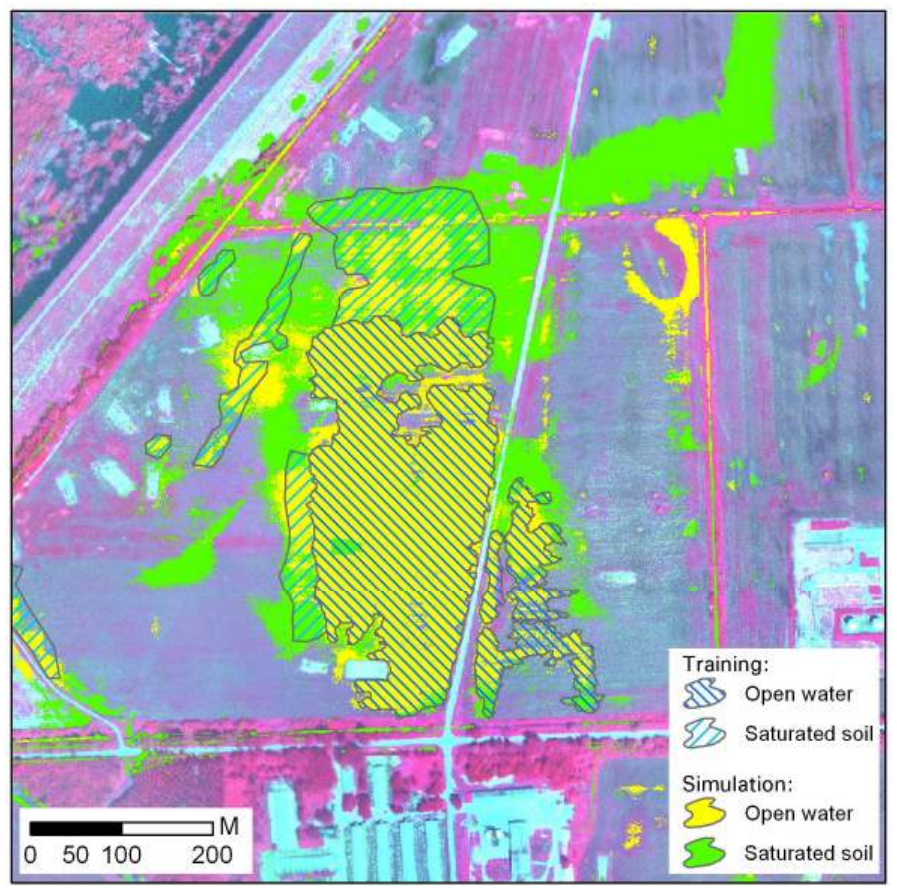

Figure 6.3 Result of a simulation based on a network that was training with three output classes (open water, saturated soil and dry soil)

Apart from relations between the network performance and the number of neurons in the hidden layer, the quantity of input data and the memory reduction function, it was also found that there is a linear relationship between the number of iterations and the time that is needed to calculate one iteration (Fig. 6.4). The individual measurements are given in Annex 3.

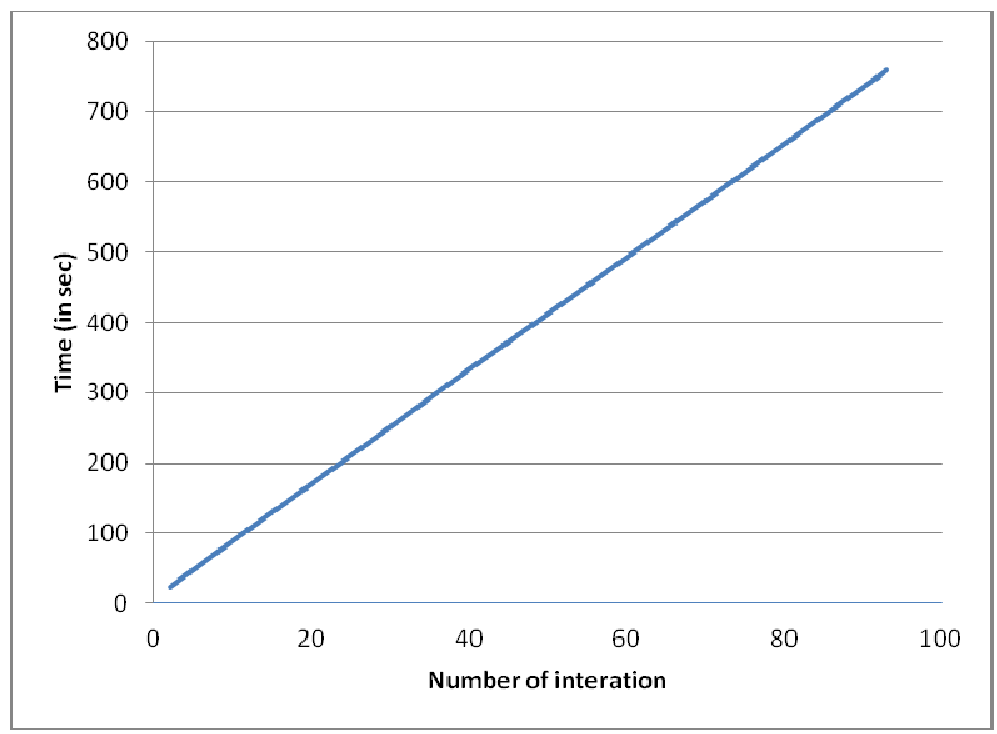

Figure 6.4 The relation between the number of iterations and the time needed for them during the training 


\subsection{Verification}

Many trainings and simulations were executed to evaluate the influence of the different input layers on the final simulated results. The results of four simulations are discussed in this paragraph (Table $6.1)$.

Table 6.1 Output results and input data for training and simulations on the training area

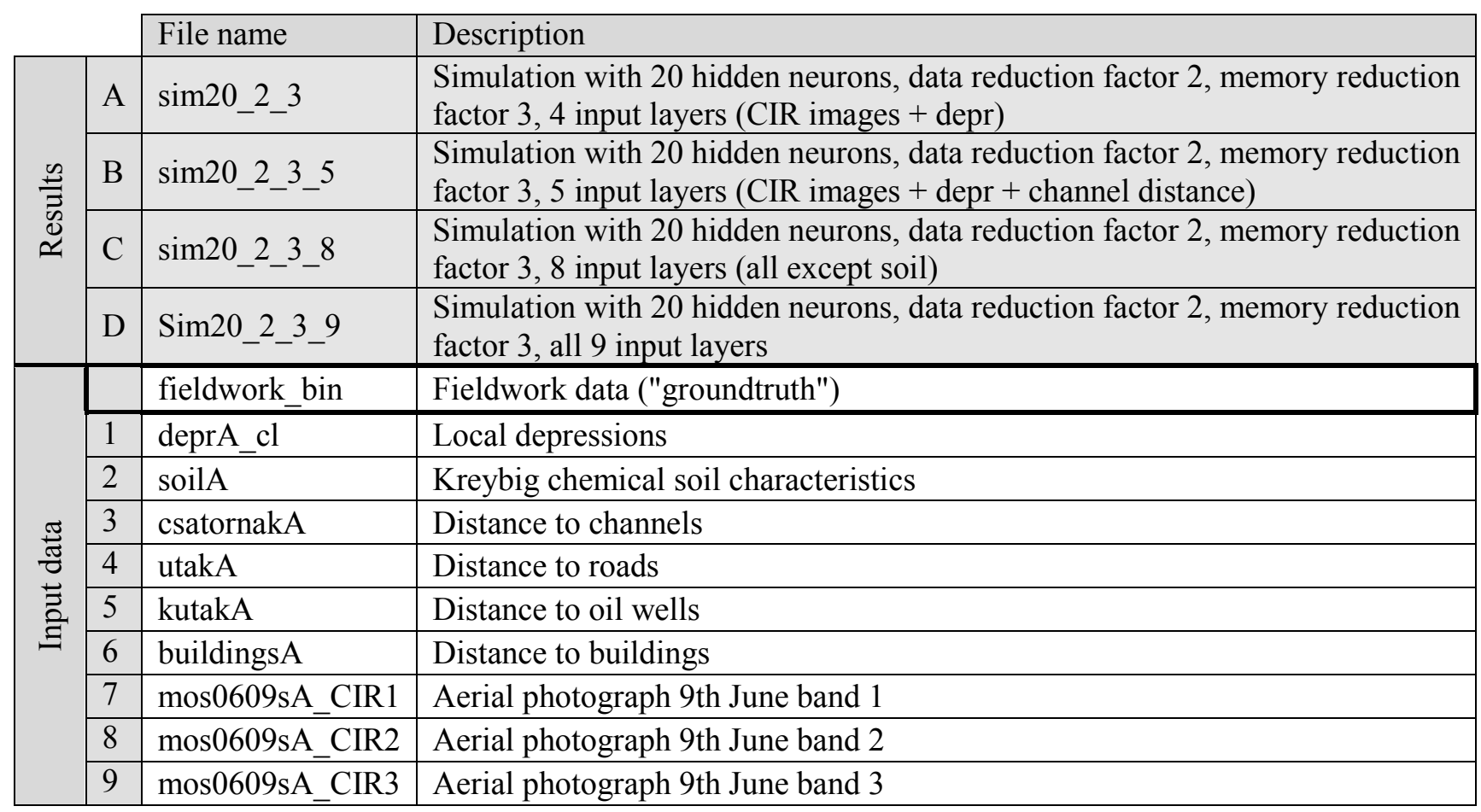

These simulations have been performed on data from the training area only, since only there, it is possible to compare the results with ground truth data. To exclude any other influences, all networks had 20 hidden neurons, a data reduction factor of 2 and a memory reduction factor of 3. The first simulation (sim20_2_3) is only based on the CIR images and the local depressions. The second (sim20_2_3_5) also incorporated the distances to channels, the third simulation (sim20_2_3_8) incorporates 8 input layers, only soil was excluded. The final simulation ( sim20_2_3_9) included all 9 input layers. The output maps of the four simulations are shown in figure 6.5. All maps are from the same area and at the same scale.

The result of the simulation with only the colour infrared images and the local depressions as input data (A) shows a lot of the inland excess water at the east part of the output map. It is unclear why in these places inundations show up. These areas are only partly characterized by local depressions. On the CIR images, they do not look much different from other areas either. During the fieldwork, they were not characterized as flooded areas. The second simulation (B) clearly shows a triangular shape from the central inland excess water area towards the west. This is an artifact resulting from the distance to channels map. 

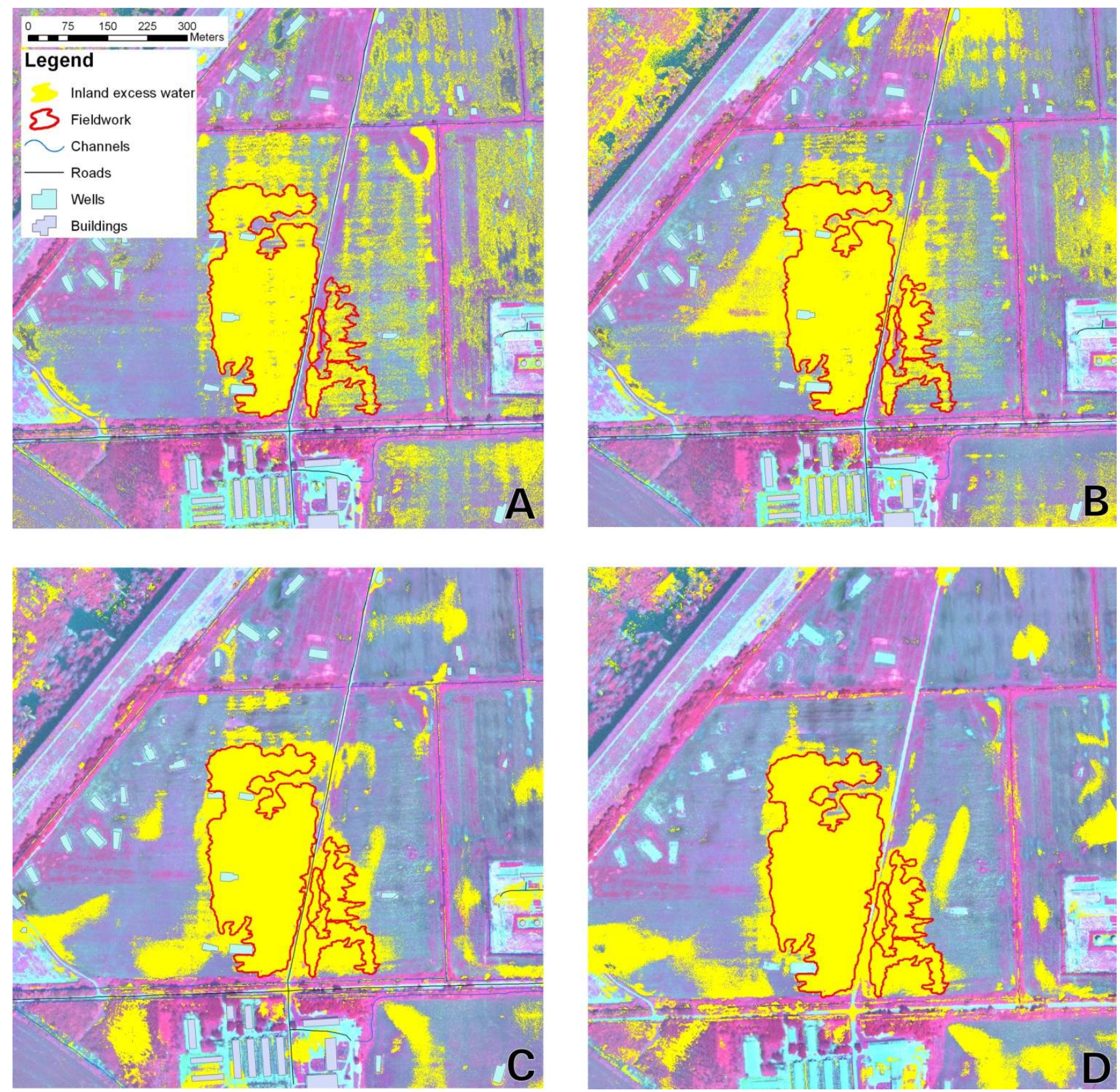

Figure 6.5 Simulation result with 20 hidden neurons, a Data reduction factor 2, a Memory reduction factor 3, and with 4 input layers (A), 5 input layers (B), 8 input layers (C) and 9 input layers (D)

The third simulation (C) incorporates all input layers except for the soil map. Its inland excess water pixels completely overlap with the fieldwork area, but identify also quite some inundations between the buildings in the southern part of the test area. These buildings form a pig farm which was in use during the inland excess water period and did not suffer from any flooding. The last simulation incorporates all input layers (D). The result looks very similar to the third simulation and the additional effect of the soil layer is not clear. This should be contributed to the small variation in soil characteristics between the three soil classes in the area. 


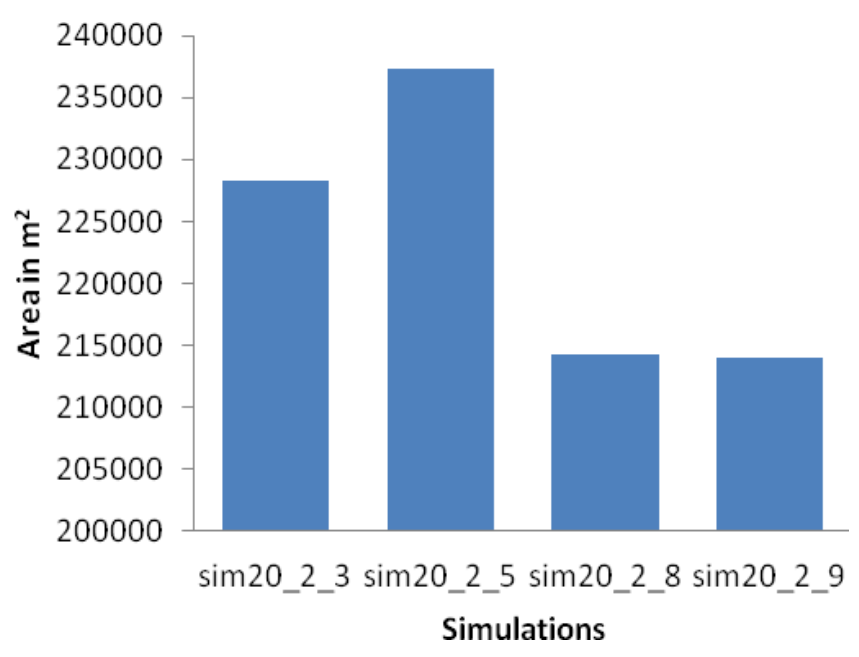

Figure 6.6 Area $\left(\right.$ in $\mathrm{m}^{2}$ ) of inland excess water in the simulation results

Figure 6.6 shows the overall area covered by inland excess water calculated according to the four simulations. The two simulations with the most input layers have the smallest inundated area. Many of the local depressions that were positively identified as inundation areas were excluded due to their distance to an anthropogenic object or soil type.

Table 6.2 provides a detailed overview of the spatial correlation between the different input layers, the training data and the simulation data. The first simulation result clearly shows the depressions in the area. These depressions have a correlation of $-0,59$ with the fieldwork data (a). This correlation is negative because the depression classes range from no depression to deep depression and the inland excess water ranges from inland excess water to no inland excess water (Fig. 4.14 and Fig. 5.4). The relatively high value shows that the relief has a strong influence on the formation of inland excess water. The correlation between the simulation and the fieldwork data is 0,76 (b). If the layer with distances from channels is added to the simulation the correlation increases to 0,83 (c). There exists a correlation between the individual channel distance layer and the fieldwork data although it is not very high: 0,37 (d). When 8 layers are used in the simulation, the correlation further increases to 0,92 (e), although the correlation between the individual layers (distance maps, and CIR bands) and the fieldwork data is low. Adding the soil input layers to the simulation slightly decreases the correlation (f). The limited influence of the soil in the simulations in this study area is also reflected in the low correlation $(0,08)$ between the fieldwork data and the soil map $(\mathrm{g})$. The values for the spatial correlations of the simulations with 8 and 9 layers (C and D) are almost equal; only when more than two decimals would be shown, minor differences would appear. For the purpose of readability this is omitted. 


\begin{tabular}{rrrrrrrrrrrrrrrrr} 
& & $\mathrm{A}$ & $\mathrm{B}$ & $\mathrm{C}$ & $\mathrm{D}$ & \multicolumn{1}{c}{ train } & 1 & 2 & 3 & 4 & 5 & 6 & 7 & 8 & 9 \\
$\mathrm{~A}$ & 1,00 & 0,91 & 0,83 & 0,83 & $0,76^{\mathrm{b}}$ & $-0,79$ & 0,07 & $-0,30$ & 0,14 & 0,13 & 0,06 & 0,23 & 0,02 & 0,04 \\
$\mathrm{~B}$ & 0,91 & 1,00 & 0,91 & 0,91 & $0,83^{\mathrm{c}}$ & $-0,73$ & 0,06 & $-0,44$ & 0,11 & 0,14 & 0,03 & 0,22 & 0,02 & 0,04 \\
$\mathrm{C}$ & 0,83 & 0,91 & 1,00 & 0,99 & $0,92^{\mathrm{e}}$ & $-0,66$ & 0,09 & $-0,40$ & 0,18 & 0,17 & 0,11 & 0,19 & 0,02 & 0,03 \\
$\mathrm{D}$ & 0,83 & 0,91 & 0,99 & 1,00 & $0,92^{\mathrm{f}}$ & $-0,66$ & 0,09 & $-0,40$ & 0,18 & 0,17 & 0,11 & 0,19 & 0,02 & 0,03 \\
train & 0,76 & 0,83 & 0,92 & 0,92 & 1,00 & $-0,59^{\mathrm{a}}$ & 0,08 & $-0,37$ & 0,16 & 0,16 & 0,09 & 0,18 & 0,02 & 0,03 \\
1 & $-0,79$ & $-0,73$ & $-0,66$ & $-0,66$ & $-0,59$ & 1,00 & $-0,05$ & 0,19 & $-0,10$ & $-0,06$ & $-0,05$ & $-0,12$ & $-0,09$ & $-0,12$ \\
2 & 0,07 & 0,06 & 0,09 & 0,09 & $0,08^{\mathrm{g}}$ & $-0,05$ & 1,00 & 0,28 & 0,46 & 0,33 & 0,34 & 0,03 & $-0,06$ & $-0,06$ \\
3 & $-0,30$ & $-0,44$ & $-0,40$ & $-0,40$ & $-0,37^{\mathrm{d}}$ & 0,19 & 0,28 & 1,00 & 0,27 & 0,07 & 0,31 & $-0,23$ & 0,01 & $-0,02$ \\
4 & 0,14 & 0,11 & 0,18 & 0,18 & 0,16 & $-0,10$ & 0,46 & 0,27 & 1,00 & 0,14 & 0,71 & 0,03 & $-0,07$ & $-0,05$ \\
5 & 0,13 & 0,14 & 0,17 & 0,17 & 0,16 & $-0,06$ & 0,33 & 0,07 & 0,14 & 1,00 & $-0,03$ & 0,05 & $-0,01$ & $-0,04$ \\
6 & 0,06 & 0,03 & 0,11 & 0,11 & 0,09 & $-0,05$ & 0,34 & 0,31 & 0,71 & $-0,03$ & 1,00 & 0,04 & $-0,11$ & $-0,05$ \\
7 & 0,23 & 0,22 & 0,19 & 0,19 & 0,18 & $-0,12$ & 0,03 & $-0,23$ & 0,03 & 0,05 & 0,04 & 1,00 & $-0,13$ & 0,26 \\
8 & 0,02 & 0,02 & 0,02 & 0,02 & 0,02 & $-0,09$ & $-0,06$ & 0,01 & $-0,07$ & $-0,01$ & $-0,11$ & $-0,13$ & 1,00 & 0,63 \\
9 & 0,04 & 0,04 & 0,03 & 0,03 & 0,03 & $-0,12$ & $-0,06$ & $-0,02$ & $-0,05$ & $-0,04$ & $-0,05$ & 0,26 & 0,63 & 1,00
\end{tabular}

The spatial correlations were calculated using the Band Collection Statistics tool in the Spatial Analyst module of ArcGIS 10.

\subsection{Accuracy}

To carry out further evaluations of the accuracy of the simulations, the Overall Accuracy and Cohen`s Kappa (Cohen 1960, Congalton 1991, Congalton \& Green 2009, Tso B \& Mather 2009) were calculated using Cohen's Kappa and Classification Table Metrics 2.1., the freely available ESRI ArcView 3x extension for Accuracy Assessment of Spatially-Explicit Models (Jenness \& Wynne 2006).

Cohen's Kappa ( $k$ ) provides a measure of agreement between predicted values and the observed values. Its value is always less than or equal to 1 . A value of 1 implies perfect agreement and values less than 1 imply less than perfect agreement.

Table 6.3 Cohen's Kappa and the overall accuracy of 4 simulations

\begin{tabular}{|l|c|c|c|c|}
\cline { 2 - 5 } \multicolumn{1}{c|}{} & Sim20_2_3 & Sim20_2_3_5 & Sim20_2_3_8 & Sim20_2_3_9 \\
\hline Cohen's Kappa (к) & 0,76 & 0,81 & 0,86 & 0,83 \\
\hline Overall accuracy (\%) & 88 & 91 & 93 & 91 \\
\hline
\end{tabular}

The statistics are based on a random selection of 300 sample points where $50 \%$ of them was forced to be in the inland excess water areas and $50 \%$ on the dry areas of the reference fieldwork data (see $\S 4.2 .5)$. The results in table 6.3 illustrate that with 8 input layers the best results are reached $(K=$ $0,86, O C=0,93)$. If the soil layer is added, the results are worse. 
The above results show that in the study area of this research relief differences are the dominating factor in the formation of inland excess water. A limited influence of the channels was also found. The influence of the soil was small and even slightly reduced the quality of the classification. In this area, everywhere the soil has very low permeability. Obviously, in an area where there are larger differences in permeability, this would result in a larger influence of soil on the formation of inland excess water. This would also further complicate the simulation, since there may then be the horizontal as well as the vertical types of inland excess water.

\subsection{Comparison with traditional classifications}

For the comparison of the ANN results and the traditional results, the same set of 150 wet and 150 dry samples was used as described above. The result of training using the minimum distance algorithm is shown in table 6.4. The overall accuracy of this classification is $67 \%$, but many pixels are misclassified as inland excess water (36\%) as can be seen in the classified image (Fig. 6.7), where white indicates water and black indicated non-water.

Table 6.4 Minimum distance classification result (absolute number of samples)

\begin{tabular}{|l|c|c|c|}
\cline { 2 - 3 } \multicolumn{1}{c|}{} & \multicolumn{2}{c|}{ Reference data } & \multicolumn{1}{c}{ Total } \\
\hline \multicolumn{1}{c|}{ Classified data } & Water & Non-water & 186 \\
\hline Water & 119 & 67 & 114 \\
\hline Non-water & 31 & 83 & 300 \\
\hline \multicolumn{1}{|c|}{ Total } & 150 & 150 & \\
\hline
\end{tabular}

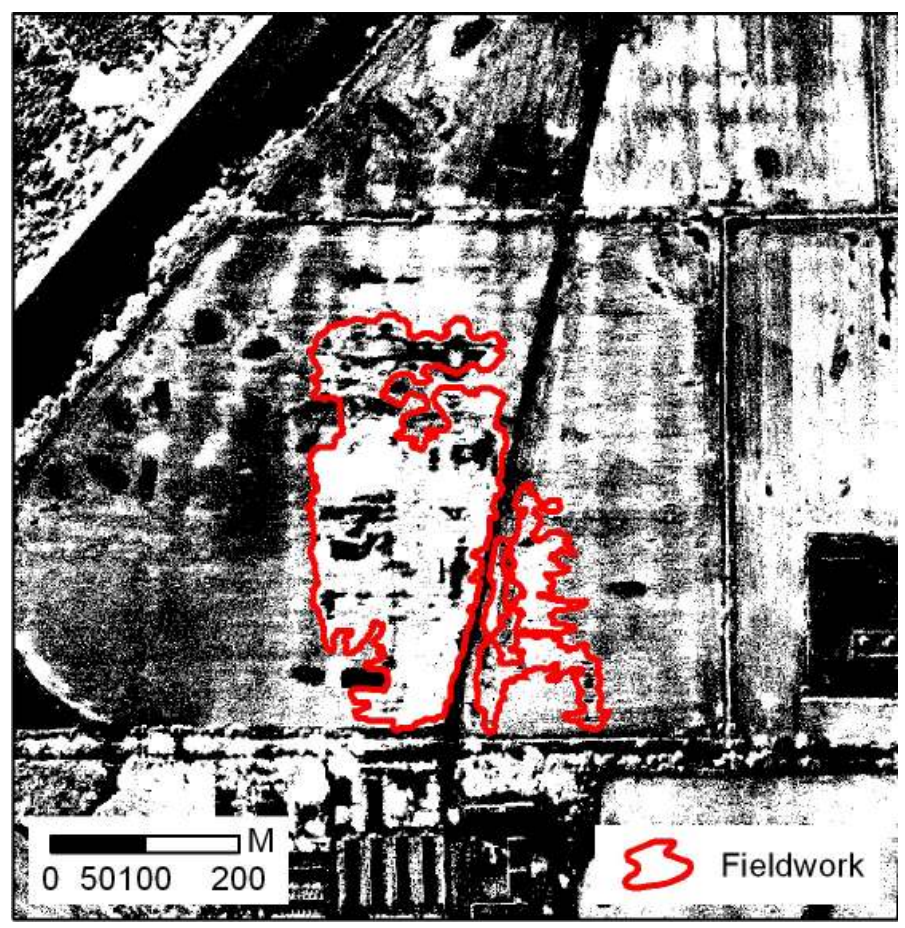

Figure 6.7 Minimum distance classification result based on two classes 
The result of training using the maximum likelihood algorithm is very similar to the minimum distance classification (Table 6.5). The overall accuracy of this classification is $69 \%$, but also here many pixels are misclassified as inland excess water (37\% and Fig. 6.8).

Table 6.5 Maximum likelihood classification result (absolute number of samples)

\begin{tabular}{|l|c|c|c|}
\cline { 2 - 4 } \multicolumn{1}{c|}{} & \multicolumn{2}{c|}{ Reference data } & \multicolumn{1}{c}{ Total } \\
\hline \multicolumn{1}{|c|}{ Classified data } & Water & Non-water & 213 \\
\hline Water & 135 & 78 & 87 \\
\hline Non-water & 15 & 72 & 300 \\
\hline Total & 150 & 150 & \\
\hline
\end{tabular}

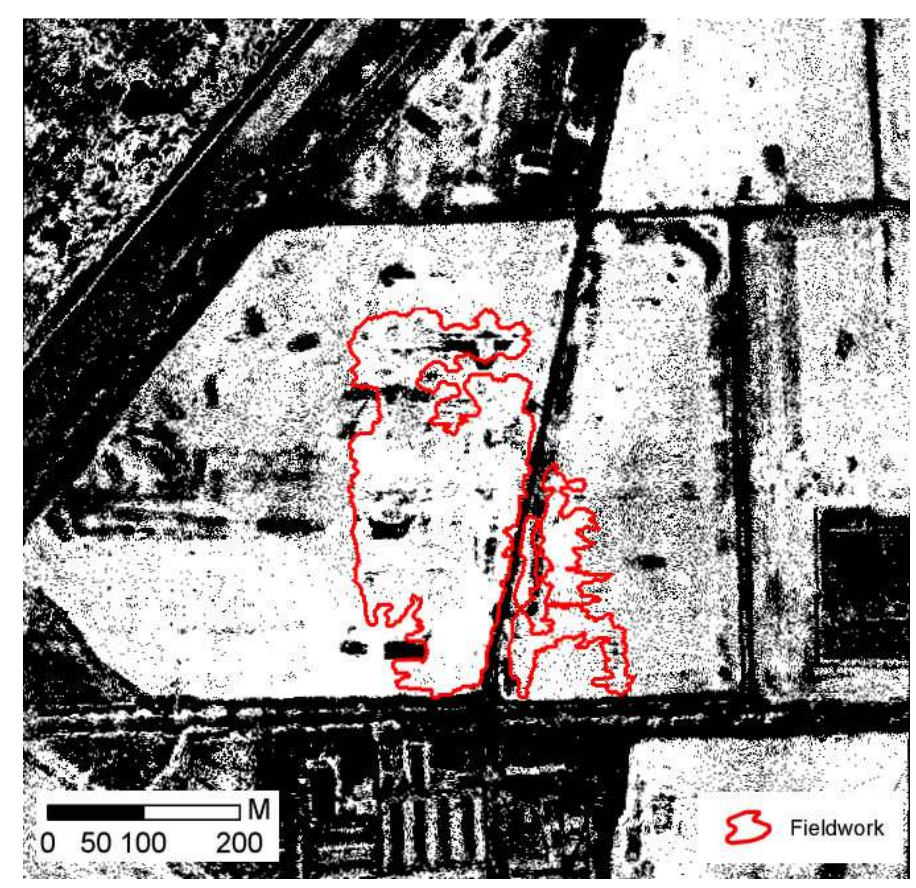

Figure 6.8 Maximum likelihood classification result based on two classes

The non-inland excess water class is a mixed class that consists of many different types of land cover, like forest, soil, buildings etcetera. To improve the results, another maximum likelihood classification was executed with a new signature set of 7 classes; concrete, road, building, forest, soil, vegetation and water. This way the spectral separability of the classes was better and the classification result improved (Fig 6.9 left). Combining the non-water classes afterwards results in a better water - non-water classification as well (Fig. 6.9 right). The overall accuracy of the water non-water classification was $70 \%$, but $40 \%$ of the water pixel is the reference data were misclassified Table 6.6). 
Table 6.6. Maximum likelihood classification result based on merged non-water classes (absolute number of samples)

\begin{tabular}{|l|c|c|c|}
\cline { 2 - 3 } \multicolumn{1}{c|}{} & \multicolumn{2}{c|}{ Reference data } & Total \\
\hline \multicolumn{1}{c|}{ Classified data } & Water & Non-water & 120 \\
\hline Water & 90 & 30 & 180 \\
\hline Non-water & 60 & 120 & 300 \\
\hline \multicolumn{1}{|c|}{ Total } & 150 & 150 & \\
\hline
\end{tabular}

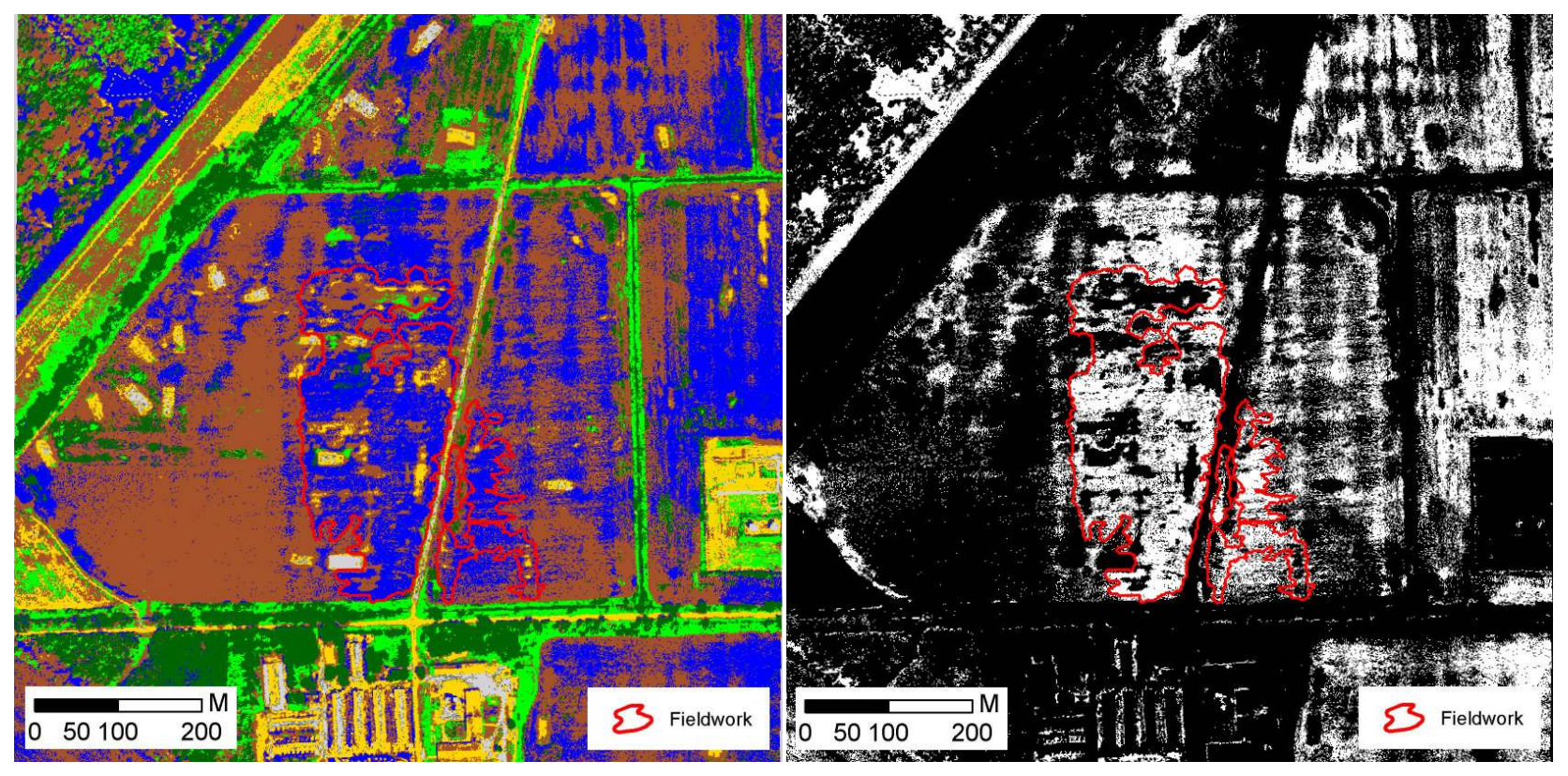

Figure 6.9. Maximum likelihood classification based on 7 classes (left) and the 6 non-water classes merged into one class (right)

It is difficult to compare the results from the traditional classifications based on the three spectral input layers with the ANN classification with 4 or more input layers. Therefore, also an ANN classification was executed using just the three spectral bands from the CIR images (Fig 6.10). 


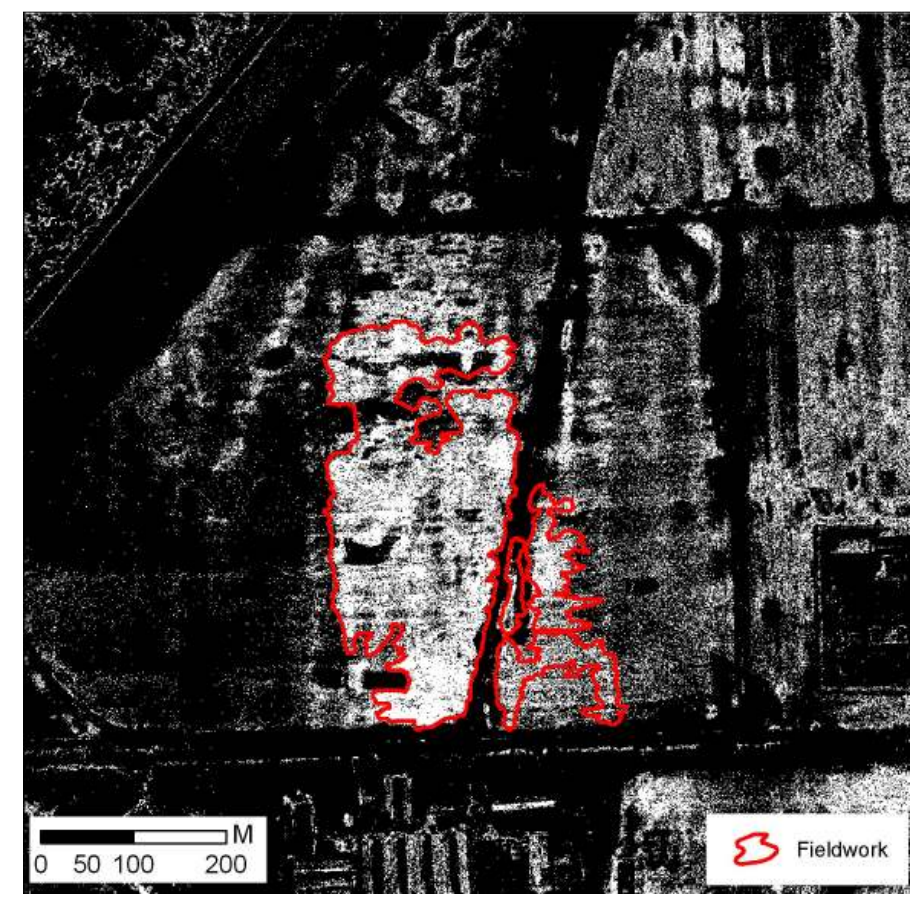

Figure 6.10 ANN classification based on three CIR bands. The settings for this classification are data reduction factor: 4, number of hidden layers: 20, memory use reduction factor: 4, transfer function for the hidden layer: logsig, and for the output layer: purelin, training function: trainlm

While comparing figure 6.9 right and figure 6.10, the resemblance is clear. Both methods find the most inland excess water in the fieldwork area, but also a lot of water to the east and northeast of that area. These areas have not been identified as inland excess water during the fieldwork. The soil in these areas was very saturated with water though. The statistical result is given in table 6.7. The overall accuracy of the ANN classification with three bands is $74 \%$ which is slightly better than the maximum likelihood classification with the reclassified non-water classes. Still, $36 \%$ of the water pixels in the reference data were misclassified.

Table 6.7 ANN classification result based on three input layers (absolute number of samples)

\begin{tabular}{|c|c|c|c|}
\cline { 2 - 3 } \multicolumn{1}{c|}{} & \multicolumn{2}{c|}{ Reference data } & \multicolumn{1}{c}{ Total } \\
\hline Classified data & Water & Non-water & 115 \\
\hline Water & 93 & 22 & 185 \\
\hline Non-water & 57 & 128 & 300 \\
\hline Total & 150 & 150 & \\
\hline
\end{tabular}

Overall, it can be concluded that the result of the maximum likelihood classification and the ANN with only three remote sensing bands is quite similar. Improving this result is possible by adding extra information to the classifications like local depressions, distance to anthropogenic objects and soil type. This results in a much higher accuracy (Table 6.8). The additional layers are not 
compatible with the remote sensing data, and therefore it is only possible to use them with the ANN approach and not with the maximum likelihood method.

Table 6.8 Summary of the classification results of different types of classifications

\begin{tabular}{|l|c|c|c|c|c|}
\cline { 2 - 5 } \multicolumn{1}{c|}{} & $\begin{array}{c}\text { Correctly } \\
\text { classified } \\
\text { water }\end{array}$ & $\begin{array}{c}\text { Correctly } \\
\text { classified } \\
\text { non-water }\end{array}$ & $\begin{array}{c}\text { Total water } \\
\text { found }\end{array}$ & $\begin{array}{c}\text { Total non- } \\
\text { water }\end{array}$ & $\begin{array}{c}\text { Overall } \\
\text { accuracy }\end{array}$ \\
\hline MD based on 2 classes & 119 & 83 & 186 & 114 & $67 \%$ \\
\hline ML based on 2 classes & 135 & 72 & 213 & 87 & $69 \%$ \\
\hline $\begin{array}{l}\text { ML with merged non-water } \\
\text { classes }\end{array}$ & 90 & 120 & 120 & 180 & $70 \%$ \\
\hline ANN two classes (3 layers) & 93 & 128 & 115 & 185 & $74 \%$ \\
\hline ANN two classes (8 layers) & 149 & 130 & 169 & 131 & $93 \%$ \\
\hline
\end{tabular}

When two classes are used, the water class is much more homogeneous compared to the non-water class, because the later one contain all subclasses, like different vegetation types, concrete and soil. This is probably the reason for the low score of non-water classes in the traditional classification with two classes. If the non-water class is split up in its subclasses during the training, and just merged after the classification, the probability of a pixel being correctly classified as non-water is much higher. This may have to do with misclassification of saturated soil or vegetation in water which are not included in the training data set. The ANN classification with only 3 layers behaves similar as the ML with merged classes. Probably, it is not capable of distinguishing the difference between saturated soils and water either. The ANN with 8 layers uses the depression data as well, this may compensate for the lack of training data.

\subsection{Conclusions}

Many complex and interrelated factors influence the formation of inland excess water. Since it is impossible to include or measure all of them, the neural network approach has provided a pragmatic basis for classifying the locations of the inundations. New data sets can easily be integrated to improve the calculations when they become available.

Integrating the functionality of the GIS and the ANN toolbox improves the efficiency of the modelling process. Performing all steps from within the GIS allows for flexible testing of different trainings and simulations.

The framework works as expected with the presented data set. The larger data sets also result in proper delineation of inland excess water patches, but present long training times. Due to the nature of spatial data, very large matrices are created as input data for the network. This results in performance problems. By reducing the amount of input pixels from the input data sets, the performance of the system is improved. During the simulation phase, it is not possible to reduce the 
size of the input data set by subsampling, because the simulation is executed on all pixels. In this case, the out of memory problems can only be prevented by using computers with lager internal memory or by adapting internal functions of (the Neural Network Toolbox of) Matlab. These changes include removing error checking which prevents Matlab from duplicating the matrix that is used as input for the network.

The results of most simulations show a clear distinction between water and dry soils. In reality this is a fuzzy boundary. Intermediate classes like saturated soil and vegetation in water exist as well. These classes were just once taken into account in the training set. Extra field data is needed to incorporate these classes and to be able to derive them in the simulation properly.

The simulations and spatial correlation between the input data and the ground truth data show that the influence of the relief on the development of inland excess water in the study area is large. The influence of the other data sets is smaller, although when used all together they have a large spatial correlation with the fieldwork data.

The artificial neural network approach gives better results than traditional classification, especially when more (GIS) data sets are incorporated. Since the factors involved in the development of inland excess water are diverse and consist of different data types than the aerial photographs, their combined use is not possible with traditional classification methods.

With other statistical techniques, the weights of the individual factors causing inland excess water are adapted to match earlier observations or are based on expert knowledge. The calculation of the weights is an intrinsic part of the training of a network; therefore no user input is required. This reduces errors and makes the method easier adaptable to other geographic regions.

A disadvantage of artificial neural networks is the difficulty to interpret their results. It is sometimes difficult to explain the patterns in the simulation results, since the functional form of the relationship between the input variables and the output layer remains hidden.

This dissertation shows that artificial neural networks can be used to delineate inland excess water. There are still many possibilities for improvements. The current input data set is limited in its scope. On purpose, an area was selected where the influence of the soil is spatially homogeneous. Applying the same method in an area with larger soil variation may yield useful insight in its influence on the development of inland excess water. In that case, it might be possible to evaluate the usefulness of the method for classifying the vertical type of inland excess water as well.

Another improvement regarding the size of the study area would be welcome; since inland excess water covers large areas, it would be good to extend the training and simulation areas. To circumvent problems due to the high computational demands of the methods several options are possible. First, there may be options to improve the performance of the developed computer programs by optimizing the code. Second, using a stronger computer and making use of parallel processing would increase the calculation capacity. Third, reducing the spatial resolution would 
reduce the calculation demands. It would be interesting to study which spatial resolution is sufficient to estimate inland excess water accurately.

Some people regard the land as agricultural land that get flooded once in a while; other people regard the same land as wetland areas that are also used as agricultural land. The point of view determines how harmful inland excess water is perceived to be. The result of this study can help to understand better where inland excess water occurs. This may help to improve water management schemes for inland excess water and to create a better balance between dry and wet periods. 


\section{Acknowledgements}

I would not have been able to accomplish this work without the support of many people. Therefore, I would like to thank everybody who was there to help me.

Quite some years ago, when we drove back from a conference in Mórahalom, Szatmári József talked about the use of artificial neural networks and the many possibilities they could have in geographic research. Some time later, we continued the discussion and started to get the feeling that it would be promising to combine neural networks and inland excess water. This was the basis of several years of work that resulted in this dissertation. I wish to thank Szajó for giving the idea and for his supervision of my work.

I would also like to thank my other supervisor, Mezősi Gábor who gave me lots of feedback on the dissertation and provided guidance and motivation. Fortunately, he sometimes also urged me to hurry, because otherwise, I probably would have never finished. I would also like to express my sincere gratitude to him for giving me the opportunity to come to work at the department. Without his faith, our move to Hungary would not have been possible.

This brings me to my other colleagues who were extremely supportive when I arrived in Hungary. With the help of Mitics, Papesz and Zalán, I managed to get acquainted during the first couple of months in Szeged. Later, Zalán became my roommate in the office. He was and is a continuous support in all the work I do. It would have been very hard to write this dissertation without his help.

Many thanks to János, Karcsi Andi and Timi as well for enlightening the theoretical background of inland excess water from different perspectives. Also Kati's help in proofreading the dissertation is greatly appreciated.

Barsi Árpád's detailed review with numerous comments and suggestions for improvements, especially related to artificial neural networks really improved the dissertation. Hopefully, this will be the start of future cooperation on the topic.

Furthermore, I would like to thank my colleagues Zsuzsi and Viki, who I continuously bothered with questions about the formalities of writing a $\mathrm{PhD}$. Also many thanks for their nice company and good friendship.

To my other colleagues from the department, I would like to express my gratitude as well. Thanks for helping me getting around at the university, for teaching me the Hungarian "dos and don'ts" and how to speak your difficult language.

I would also like to show my appreciation for the financial support I received from the project "Development of an INLAND EXCESS WATER-INFO system" (Economic Operative Program: GOP - 1.1.1 - 08 / $1-2008-0025)$. 
The continuous warmth and happiness I receive from my Hungarian family deserves special thanks. Their positive view of life and enormous support is greatly appreciated. My Dutch family is sometimes far away, but their support is invaluable. My father's subtle, positive pressure kept me focused and determined.

Above all, I would like to express my warmest gratitude to my wonderful family Mónika, Nina and Lukas. Love you.

Boudewijn van Leeuwen

Szeged, June 2012 


\section{References}

Agarwal P. \& Skupin A., 2008, Self-Organising Maps: Applications in Geographic Information Science. New Jersey: John Wiley \& Sons Ltd. 214 p.

Agrárszektor, 2011, Közel 200 milliárdos a mezőgazdasági kár, agrarszektor.hu http://agrarszektor.hu/hir/528/kozel_200_milliardos_a_mezogazdasagi_kar.html [10-04-2011].

Allen R.G., Pereira L.S., Raes D., Smith M., 1998, Crop evapotranspiration - Guidelines for computing crop water requirements, FAO Irrigation and Drainage Papers No 56, FAO, http://www.fao.org/docrep/X0490E/X0490E00.htm [09-08-2011].

Amini J., 2008, Optimum Learning Rate in Back-Propagation Neural Network for Classification of Satellite Images (IRS-1D), Scientia Iranica 15, 6, pp. 558-567.

Atkinson P.M. \& Tatnall A.R.L., 1997, Introduction neural networks in remote sensing. International Journal of Remote Sensing 18, p. 699-709.

Barsi Á., 1997, Landsat-felvétel tematikus osztályozása neurális hálózattal, Geodézia és kartográfia XLIX/4, pp. 21-28.

Barsi Á., 1999, Koordinátatranszformáció megoldása neurális hálózattal, Geodézia és kartográfia 10, pp. 12-18.

Barsi Á., Gáspár K., Szepessy Zs., 2010, Unsupervised classification of high resolution satellite imagery by self-organizing neural network, AGD Landscape \& Environment 4, 1, pp. 37-44.

Barta K. \& Szatmári J., 2010, Antropogén hatások a belvíz-képződésben, Hidrológiai közlöny 90-2, pp. 23-25.

Barta K., Szatmári J., Post A., 2011, A belvízképződés és az autópályák kapcsolata, Foldrajzi Kozlemenyek, 135, 4, pp. 379-387.

Barta K., 2012, Meteorológiai és talajtani monitoring alapuló belvízi elörejelzés dél-alföldi mintaterületen, Journal of Env. Geogr. (In press).

Bartholy J., Pongrácz R., Gelybó Gy., 2007, Regional climate change expected in Hungary for 2071-2100, Applied ecology and environmental research 5, 1, pp. 1-17.

Bartos T., 2000, Kinn vagyunk a vízböl, Ökotáj, 25-26., pp. 75-90.

Benediktsson J.A., Swain P.H., Ersoy O.K., 1990, Neural Network approaches versus statistical methods in classification of multisource remote sensing data, IEEE Transactions on geoscience and remote sensing 28, No 4. pp. 540 - 552.

Benyhe B. \& Kiss T., 2012, Morphometric analysis of agricultural landforms In lowland ploughed fields using high resolution digital elevation models, Carpth. j. of Earth and Environmental Sciences 7,3 , pp. $71-78$.

Bishop C.M., 1995, Neural networks for pattern recognition, Oxford university press, 482 p. 
Bowden G.J., Dandy G.C., Maier H.R., 2005, Input determination for neural network models in water resources applications. Part 1 - Background and methodology, Journal of Hydrology 301, pp. 75-92.

Bozán Cs., Pálfai I., Pásztor L., Kozák P., Körösparti J., 2005, Mapping of Excess Water Hazard in Békés and Csongrád Counties of Hungary. ICID $21^{\text {st }}$ European Regional Conference Integrated Land And Water Resources Management: Towards Sustainable Rural Development, CD-ROM, 1519 May 2005, Frankfurt (an Oder) and Slubice, Germany and Poland, 4 p.

Bozán Cs, Körösparti J., Pásztor L., Kuti L., Kozák P., Pálfai I., 2009, GIS-based Mapping of excess water inundation hazard in Csongrád county (Hungary), Proceedings of the International Symposia on Risk Factors for Environment and Food Safety \& Natural Resources and Sustainable Development, Faculty of Environmental Protection, November 6-7 Oradea 2009, pp. 678 - 684.

Büttner Gy., Maucha G., Bíró M., Kosztra B., Pataki R., Petrik O., 2004, National land cover database at scale 1:50,000 in Hungary, EARSeL eProceedings 3, 3/2004, pp. 323-330.

Chen T., Niu R.-Q., Wang Y., Li P.-X., Zhang L.-P., Du B., 2011, Assesment of spatial distribution of soil loss over the upper basin of Miyun reservoir in China based on RS and GIS techniques, Environ. Monit. Assess. 179, pp. 605-617.

Choi J., Oh H-J., Lee H-J., Lee C., Lee S., 2012, Combining landslide susceptibility maps obtained from frequency ratio, logistic regression, and artificial neural network models using ASTER images and GIS , Engineering Geology 124, pp. 12-23.

Cohen J., 1960, A coefficient of agreement for nominal scale, Educational and Psychological Measurement 20, pp 37-46.

Coleman A.M., 2008, An adaptive Landscape classification procedure using geoinformatics and artificial neural networks. Amsterdam 195 p.

Congalton R.G., 1991, A review of assessing the accuracy of classifications of remotely sensed data, Remote sensing of the Environment 37, pp. 35-46.

Congalton R.G. \& Green K., 2009, Assessing the accuracy of remotely sensed data, principles and practices, Second edition, CRC Press, 183 p.

Csekő Á., 2003, Árvíz- és belvízfelmérés radar felvételekkel, Geodézia és Kartográfia 2003, 2, pp. $16-22$.

Csornai G., Lelkes M., Nádor G., Wirnhardt Cs., 2000, Operatív árvíz- és belvíz-monitoring távérzékeléssel. Geodézia és Kartográfia, 2000. 5.

Dai E., Wu S., Shi W., Cheung C.-K., Shaker A., 2005, Modeling change-pattern-value dynamics on land use: an integrated GIS and artificial neural networks approach, Journal of Environmental Management 36, 4, pp. 576-591.

Dawson C.W. \& Wilby R.L., 2001, Hydrological modelling using artificial neural networks, Progress in Physical Geography 25, 1, pp. 80-108.

Demuth H., Beale M., Hagan M., 2010, Neural Network Toolbox 6, User's Guide. The Mathworks, $901 \mathrm{p}$. 
Duch W. \& Jankowski N., 2001, Transfer functions: hidden possibilities for better neural networks, proceedings - European Symposium on Artificial Neural Networks, pp. 81-94.

Farkas J. Zs., 2010, Mesterséges neurális hálózatok alkalmazása a magyar kistérségek földrajzi típusainak meghatározásában, In: Matematikát, fizikát és informatikát oktatók, XXXIV.Országos és nemzetközi konferenciája. Békéscsaba, Magyarország, Szent István Egyetem, CD-ROM. (ISBN 978-963-269-201-2), p. 10.

Farsang A., 2011, A belvízképződés talajtani okai, Presentation at the Csongrád megyei mérnőki kamara inland excess water conference, 11 February 2011.

Freeman J.A. \& Skapura D.M., 1991, Neural Networks: Algorithms, Applications and Programming Techniques, Addison-Wesley, Reading (MA), $550 \mathrm{p}$.

Derrick N. \& Widrow B., 1990, Improving the learning speed of 2-layer neural networks by choosing initial values of the adaptive weights, Proceedings of the International Joint Conference on Neural Networks 3, p 21-26.

Gurney K., 1997, An introduction to neural networks, UCL Press Limited, London, 234 p.

Hagan M.T., Demuth H.B., Beale M.H., 1996, Neural Network Design, Boston, MA., PWS Publishing, $734 \mathrm{p}$.

Hewitson B.C. \& Crane R.G., 1994, Neural Nets: Applications in Geography. Dordrecht: Kluwer Academic Publishers, 194 p.

Hilbert D.W. \& Ostendorf B., 2001, The utility of artificial neural networks for modelling the distribution of vegetation in past, present and future climates, Ecological Modelling 146, pp. 311327.

Horváth J., 2011, Define of depositional environment using neural network, Geologia Croatica 64, $3, \mathrm{pp} 251-258$.

Huang B. \& Jiang B., 2002, AVTOP: a full integration of TOPMODEL into GIS, Environmental Modelling \& Software 17, pp. 261-268.

Jafar R., Shahrour I., Juran I., 2010, Application of Artificial Neural Networks (ANN) to model the failure of urban water mains. Mathematical and Computer Modelling 51, pp. 1170-1180.

Jayawardena A.W., Fernando D.A.K., Zhou M.C., 1997, Comparison of multilayer perceptron and radial basis function networks as tools for flood forecasting, In: IAHS Publications-Series of Proceedings and Reports-Intern Assoc Hydrological Sciences 239, Wallingford Oxfordshire: IAHS, pp. 173-182.

Jenks G.F., 1967, The Data Model Concept in Statistical Mapping, International Yearbook of Cartography 7, pp. 186-190.

Jenness J. \& Wynne J.J., 2006, Kappa analysis (kappa_stats.avx) extension for ArcView 3.x. Jenness Enterprises. http://www.jennessent.com/arcview/kappa_stats.htm.[10-01-2012].

Khan S.D., 2005, Urban development and flooding in Houston Texas, inferences from remote sensing data using neural network technique, Environ Geol. 47, pp. 1120-1127. 
Keveiné Bárány I., 1988, Talajföldrajzi vizsgálatok Szeged környékén, Alföldi Tanulmányok 12, pp. 5-32.

Kohonen T., 2001, Self-Organizing Maps, Spinger Verlag Berlin, 501 p.

Koncsos L. \& Balogh E., 2009, Belvízkockázatok számitása korszerü hidroinformatikai eszközökkel, XXVII Országos vándorgyülés, Baja, 1-3 july, 2009.

http://www.hidrologia.hu/vandorgyules/27/dolgozatok/04koncsos-balogh.htm [23-03-2011].

Kozák P., 2006, A belvízjárás összefüggései az Alföld délkeleti részén, különös tekintettel a vízkárelhárítás európai igényeire. Doktori Értekezés, SZTE Földtudományi Doktori Iskola, 86 p.

Kozák P., 2008, A belvízi kockázattérképezés főbb kihívásai és eszközrendszere, XXVI Országos vándorgyülés, Miskolc, 2-4 july 2008.

Kozák P., 2011, Belvízi jelenségek az Alsó-Tiszai vízgyűjtőkön az 1955-2010 közötti időszakban, In: Rakonczai J. (ed.), Környezeti változások és az Alföld, A nagyalföldi Alapítvány kötetei 7, pp. $127-136$.

Kovács L. \& Deme A., 2008, A Tiszaberceli szivattyútelep rekonstrukciós terve XXVI Országos vándorgyülés, Miskolc, 2-4 july 2008, http://www.hidrologia.hu/vandorgyules/26/3szekcio/KovacsDemeOK.htm [12-05-2012]

Körösparti J. \& Bozán Cs., 2008, A földárjás területek vízgazdálkodási problémái. Magyar Hidrológiai Társaság, XXVI Országos vándorgyűlés, Miskolc, 2-4 july 2008,.

http://www.hidrologia.hu/vandorgyules/26/3szekcio/Korosparti-BozanOK.htm [12-05-2012]

Körösparti J., Bozán Cs., Pásztor L., Kozák P., Kuti L., Pálfai I., 2009, GIS alapú belvízveszélyeztetettségi térképezés a Dél-Alföldön, Magyar Hidrológiai Társaság, XXVII Országos vándorgyülés, Baja, 1-3 july 2009,

http://www.hidrologia.hu/vandorgyules/27/dolgozatok/04korosparti_janos.htm [23-03-2011].

Krasnopolskya V.K. \& Chevallier F., 2003, Some neural network applications in environmental sciences. Part II: advancing computational efficiency of environmental numerical models, Neural Networks 16, pp. 335-348.

Kreybig L., 1956, Az agrotechnika tényezői és irányelvei, Akadémiai Kiadó, Budapest, 819 p.

Kuti L, Kerék B, Vatai J., 2006, Problem and prognosis of excess water inundation based on agrogeological factors, Carpth. J. of Earth and Environmental Sciences 1, 1, pp. $5-18$.

Ladányi Zs., Rakonczai J., van Leeuwen B., 2011, Evaluation of precipitation-vegetation interaction on a climate-sensitive landscape using vegetation indices, J. Appl. Remote Sens. 5.

Lakes, T., Müller D., Krüger C., 2009, Cropland change in southern Romania: a comparison of logistic regressions and artificial neural networks, Landscape Ecology, 24, pp. 1195-1206.

Lara F., 1998, Artificial neural networks: An introduction, Journal of the Mexican society of Instrumentation 3, 9, pp. 5-10.

Licskó B, 2009, A belvizek légi felmérésének tapasztalatai, XXVII Országos vándorgyülés, Baja, 13 july 2009, http://www.hidrologia.hu/vandorgyules/27/dolgozatok/04licsko_bela.htm [17-082011]. 
Lillesand T.M., Kiefer R.W., Chipman J.W., 2004, Remote Sensing and Image Interpretation, Wiley, $784 \mathrm{p}$.

van Leeuwen B., Mezősi G., Tobak Z., Szatmári J., Barta K., 2012, Identification of inland excess water floodings using an artificial neural network, Carpathian Journal of Earth and Environmental sciences. (In review).

van Leeuwen B., Szatmári J., Tobak Z., Németh Cs., Hauberger G., 2009a, Opportunities for the generation of high resolution digital elevation models based on small format aerial photography, HunDEM Conference Proceedings, 2009, Miskolc, Hungary, 5 p. http://www.unimiskolc.hu/ fkt/Hundem_es_Geoinfo_2009/Cikkek/vanLeeuwen_et_al.pdf [12-05-2012].

van Leeuwen B., Tobak Z., Szatmári J., 2008, Development of an integrated ANN - GIS framework for inland excess water monitoring, Journal of Env. Geogr. I, 3-4, pp. 1-6.

van Leeuwen B., Tobak Z., Szatmári J., Barta K., 2010, Új módszerek alkalmazása a belvizek keletkezésének vizsgálatában és monitorozásában, In: Lóki J., Demeter G. (Eds.) Az elmélet és gyakorlat találkozása a térinformatikában I, Debrecen. pp. 121-130.

van Leeuwen B., Tobak Z., Szatmári J., Mucsi L., Kitka G., Fiala K., Rakonczai J., Mezősi G., 2009b, Small format aerial photography: a cost effective approach for visible, near infrared and thermal digital imaging, . In: A. Car, G. Griesebner, J. Strobl (Eds.), Geospatial Crossroads @ GI_Forum' 09, Proceedings of the Geoinformatics Forum Salzburg, Heidelberg, 2009, pp. 200-209.

Malvic T. \& Prskalo S., 2007, Some benefits of the neural approach in porosity prediction, NAFTA 58,9 , pp. 455-461.

Marosi S. \& Somogyi S., 1990, Magyarország kistájainak katasztere I (Hungarian landscape cadastre), Budapest, MTA FKI, 1023 p.

Mas J.F., Puig H., Palacio J.L., Sosa-Lopez A., 2004, Modelling deforestation using GIS and artificial neural networks, Environmental modelling and software 19, pp. 461-471.

Masocha M. \& Skidmore A.K., 2011, Integrating conventional classifiers with a GIS expert system to increase the accuracy of invasive species mapping, International journal of Applied earth observation and geoinformation 13, pp. 487-494.

Meijerink A.M.J., Gieske A.S.M., Vekerdy Z., 2005, Surface energy balance using satellite data for the water balance of a traditional irrigation - Wetland system in SW Iran, Irrigation and Drainage Systems 19, 1, pp 89-105.

Mezősi G., 1983, Szeged geomorfológiai vázlata, Alföldi Tanulmányok 7, pp. 59-75.

McClelland J.L. \& Rumelhart D.E., 1986, Parallel Distributed Processing. Volume 2: Psychological and Biological Models, MIT Press, 611 p.

McClelland, J.L., 2011, Explorations in Parallel Distributed Processing: A Handbook of Models, Programs, and Exercises. http://www.stanford.edu/group/pdplab/pdphandbook/ [06-10-2011].

McCulloch W.S. \& Pitts W., 1943, A logical calculus of the ideas immanent in nervous activity, Bulletin of Mathematical Biophysics 5, pp. 115 - 133. 
Moonjun R., Farshad A., Shrestha D.P., Vaiphasa C., 2010, Artificial Neural Network and Decision Tree in Predictive Soil Mapping of Hoi Num Rin Sub-Watershed, Thailand, In: Progress in Soil Science 2, pp. 151-164.

MTA ATK TAKI-Agrotopo, 2011, http://www.mta-taki.hu/en/departments/gis-lab/agrotopo_en [01.12.2011].

MTA ATK TAKI-Kreybig Soil map, 2011, http://www.mta-taki.hu/hu/osztalyok/gislabor/dktir_kreybig [01-12-2011].

Mucsi L., 2001, Characterisation of oil-industrial contamination using aerial and thermal images, In: Buchroithner (Ed.), Proceedings of the 20th EARSeL symposium Dresden: A Decade of TransEuropean Remote Sensing Cooperation, Balkema, Rotterdam, pp. 373-377.

Mucsi L. \& Henits L., 2011, Belvízelöntési térképek készítése közepes felbontású ürfelvételek szubpixel alapú osztályozásával, Földrajzi Közlemények 135, 4, pp. 365-378.

Mutanga O. \& Skidmore A.K., 2004, Integrating imaging spectroscopy and neural networks to map grass quality in the Kruger National Park, South Afrika, Remote sensing of Environment 90, pp. 104-115.

Ni J.R. \& Xue A., 2003, Application of artificial neural networks to the rapid feedback of potential ecological risk in flood diversion zone, Engineering Applications of Artificial Intelligence 16, pp. 105-119.

OMSz 2012, Szeged éghajlati jellemzöi, http://www.met.hu/eghajlat/magyarorszag_eghajlata/varosok_jellemzoi/Szeged/ [12-05-2012]

Openshaw S. \& Abrahart R.J., 2000, GeoComputation, CRC Press, 428 p.

Pacifici F., Chini M., Emery W.J., 2009, A neural network approach using multi-scale textual metrics from very high-resolution panchromatic imagery for urban land-use classification, Remote sensing of Environment 113, pp. 1276-1292.

Pálfai I., 2000, Az Alföld belvízi veszélyeztetettsége és aszályossága. In: (Eds), A víz szerepe és jelentősége az Alföldön. A Nagyalföld Alapítvány Kötetei 6., Békéscsaba, pp. 85 - 95.

Pálfai I., 2001, A belvíz definíciói, Vízügyi Közlemények 83, 3, pp. 376-392.

Pálfai I., 2003, Magyarország belvíz-veszélyeztetettségi térképe, Vízügyi közlemények 85, 3, pp. 510-524.

Pálfai I., Bozán Cs., Herceg Á., Kozák P., Körösparti J., Kuti L., Pásztor L., 2004a, Komplex Belvíz-veszélyeztetettségi Mutató (KBM) és Csongrád megye ez alapján szerkesztett belvízveszélyeztetettségi térképe, Magyar Földrajzi Konferencia, http://geography.hu/mfk2004/mfk2004/cikkek/palfai_bozan_herceg_kozak_korosparti_kuti_pasztor .pdf [23-03-2011].

Pálfai I., 2011, Aszálos évek az Alföldön 1931-2010 között, In: Rakonczai J.(ed.), Környezeti Változások és az Alföld, Nagyalföld Alapítvány, 396 p.

Pálfai I., 2004b, Belvízek és Aszályok Magyarországon: Hidrológiai tanulmányok, Budapest, 492 p. 
Pásztor L., Pálfai I., Bozán Cs., Kőrösparti J., Szabó J., Bakacsi Zs., Kuti L., 2006, Spatial stochastic modelling of inland inundation hazard. $9^{\text {th }}$ AGILE Conference on Geographic Information Science. Visegrád, Hungary 2006.

Patay I. \& Montvajszki M., 2011, Belvíztestek matematikai modellezése, Hidrológiai közlöny 91, 1, pp. 45-49.

Pijanowski B.C., Brown D.G., Shellito B.A., Manik G.A., 2002, Using neural networks and GIS to forecast land use changes: a Land Transformation Model, Computers, Environment and Urban Systems 26, pp. 553-575.

Pijanowski B.C., Tayyebi A., Delavar M.R., Yazdanpanah M.J., 2009, Urban expansion simulation using geospatial information systems and artificial neural networks, International journal of Environmental Research 3, 4, pp. 493-502.

Pradhan B. \&, Lee S., 2007, Utilization of optical remote sensing data and gis tools for regional landslide hazard analysis using an artificial neural network model, Earth Science Frontiers 14, 6, pp. $143-152$.

Pradhan B., Lee S., Buchroithner, M.F., 2010a, A GIS-based back-propagation neural network model and its cross-application and validation for landslide susceptibility analyses, Computers, Environment and Urban Systems 34, 3, pp. 216-235.

Pradhan B. \& Lee S., 2010b, Landslide susceptibility assessment and factor effect analysis: backpropagation artificial neural networks and their comparison with frequency ratio and bivariate logistic regression modelling. Environmental, Modelling \& Software 25, pp. 747-759.

Qiu F. \& Jensen J.R., 2004, Opening the black box of neural networks for remote sensing image classification, Int. J. Remote Sensing 25, 9, pp. 1749-1768.

Rakonczai J., Mucsi L., Szatmári J., Kovács F., Csató Sz., 2001, A belvizes területek elhatárolásának módszertani lehetőségei, In: A Magyar Földrajzi Konferencia tudományos közleményei CD, Szeged.

Rakonczai J., Csató Sz., Mucsi L., Kovács F., Szatmári J., 2003, Az 1999. és 2000. évi alföldi belvíz-elöntések kiértékelésének gyakorlati tapasztalatai (Practical experiences with identification of inland excess water in the year 1999 and 2000). Vízügyi Közlemények 1998-2001. évi árvízi külön füzetek IV, pp. 317-336.

Rakonczai J, Farsang A., Mezősi G., Gál N., 2011, A belvízképződés elméleti háttere (Theoretical background of inland excess water formation), Földrajzi Közlemények 135, 4, pp. 339-350.

Retter Gy., 2006, Fuzzy, Neurális Genetikus, Kaotikus Rendszerek, Budapest: Akadémiai Kiadó, $425 \mathrm{p}$.

Ritzema H.P., 1994, Drainage principles and applications, ILRI, Wageningen, The Netherlands, $1125 \mathrm{p}$.

Rosenblatt F., 1958, The perceptron: a probabilistic model for information storage and organization in the brain, Psychological review 65, 6, pp. 386-408.

Rumelhart D.E. \& McClelland J.L., 1986, Parallel Distributed Processing. Volume 1: Foundations, MIT Press. 547 p. 
Rumelhart D.E., Widrow B., Lehr M.A., 1994, The basic ideas in neural networks, Communications of the ACM 37, 3.pp.87-92

Sárközy F., 1998, Mesterséges neurális hálózatok mint GIS függvények, Geomatikai Közlemények I, pp. 109-130.

Schlerf M., Atzberger C., 2006, Inversion of a forest reflectance model to estimate structural canopy variables from hyperspectral remote sensing data, Remote Sensing of Environment 100, pp. $281-294$.

Skidmore A.K., Turner B.J., Brinkhof W., Knowles E., 1997, Performance of a neural network: Mapping forests using GIS and remotely sensed data, Photogrammetric Engineering and Remote Sensing 63, pp. 501-514.

Somlyódy L., Nováky B., Simonffy Z., 2010, Éghajlatváltozás, szélsőségek és Vízgazdálkodás, In: Csete L. (Ed.), „Klíma-21” füzetek klímaváltozás - hatások - válaszok 61, MTA KSZI

Klímavédelmi kutatások koordinációs iroda, Budapest

Szabó J., Pásztor L., Bakacsi Zs., Zágoni B., Csökli G., 2000, 'Kreybig Digitális Talajinformatikai Rendszer (Előzmények, térinformatikai megalapozás). Agrokémia és Talajtan 49, 1-2, pp. 265-276.

Szantó G., Mucsi L., van Leeuwen B., 2008, Application of self-organizing neural networks for the delineation of excess water areas, Journal of Env. Geogr. I, 3-4. pp. 15-20.

Szantó G., Mucsi L., van Leeuwen B., 2012, Classification of remote sensing images using selforganizing neural networks, In: Geiger J., Pál Molnár E., Malvic T. (Eds.), New horizons in Central European geomathematics, geostatistics and geoinformatics, Institute of Geosciences, University of Szeged, pp. 141-149.

Szatmári J., Szíjj N., Mucsi L., Tobak Z., van Leeuwen B., Lévai Cs., Dolleschall J., 2012, Comparing LIDAR DTM with DEM-5 of Hungary, In: Geiger J., Pál Molnár E., Malvic T. (Eds.), New horizons in Central European geomathematics, geostatistics and geoinformatics, Institute of Geosciences, University of Szeged, pp. 151-158.

Szatmári J., Szíjj N., Mucsi L., Tobak Z., van Leeuwen B., Lévai Cs., Dolleschall J., 2011a., A belvízelöntések térképezését és a belvízképződés modellezését megalapozó térbeli adatgyüjtés. In. Lóki J. (Ed.) Az elmélet és gyakorlat találkozása a térinformatikában II., Debrecen. pp. 27-35.

Szatmári J, Tobak Z., van Leeuwen B., Dolleschall J., 2011b, A belvízelöntések térképezését megalapozó adatgyüjtés és a belvízképződés modellezése neurális hálózattal, Földrajzi Közlemények 135, 4, pp. 351-363.

Strahler A.N. ,1975, Physical geography, New York, Wiley, 643 p.

Tarboton D.G., Bras R.L., Rodriguez-Iturbe I., 1991, On the Extraction of Channel Networks from Digital Elevation Data. Hydrological Processes 5, pp. 81-100.

Tayyebi A., Pijanowski B.C., Tayyebi A.H., 2011, An urban growth boundary model using neural networks, GIS and radial parameterization: An application to Tehran, Iran, Landscape and Urban Planning 100, pp. 35-44.

Thirumalaiah K. \& Deo M.C., 1998, Real-time flood forecasting using neural networks, ComputerAided Civil and Infrastructure Engineering 13, pp. 101-111. 
Thyll Sz. \& Bíró T., 1999, A belvíz-veszélyeztetettség térképezése, Vízügyi Közlemények, LXXXI,, 4, pp. 709-718.

Tou J.T. \& Gonzalez R.C., Pattern recognition principles, Addison-Wesley, London, 1974. p. 377.

Tobak Z., Kitka G., Szatmári J., van Leeuwen B., Mucsi L., 2008a, Kisgépes, Kisformátumú (SFAP) CIR légifelvételek készítése, feldolgozása és alkalmazása környezeti vizsgálatokban (Acquisition, processing and application of colour infrared images using small format aerial photography). IV. Magyar Földrajzi Konferencia Tudományos Közleményei CD, Debrecen, Hungary

Tobak Z., Szatmári J., van Leeuwen B., 2008b, Small format aerial photography - remote sensing data acquisition for environmental analysis, Journal of Env. Geogr I, 3-4, pp. 21-26.

Tso B. \& Mather P., 2009, Classification Methods for Remotely Sensed Data, Second Edition, CRC Press, $376 \mathrm{p}$.

Unger J., Gál T., Rakonczai J., Mucsi L., Szatmári J., Tobak Z., van Leeuwen B., Fiala K., 2010, Modeling of the urban heat island pattern based on the relationship between surface and air temperatures. Időjárás 114, 4, pp. 287-302.

Vámosi S., 2002, A belvizek hatása az alföldi régiók fejlesztésére, Ph.D. Disszertáció, Debreceni Egyetem, $108 \mathrm{p}$.

Várallyay Gy., 2010, A talaj, mint víztározó; talajszárazodás, In: Csete L. (Ed.), „Klíma-21” füzetek klímaváltozás - hatások - válaszok 59, MTA KSZI Klímavédelmi kutatások koordinációs iroda, Budapest, pp. 3 - 25.

Várallyay G., Szűcs L., Murányi A., Rajkai K., Zilahy P., 1979, Magyarország termőhelyi adottságait meghatározó talajtani tényezők 1:100.000 méretarányú térképe. I, Agrokémia és Talajtan 28, pp. 363-384.

Várallyay G., Szűcs L., Murányi A., Rajkai K., Zilahy P., 1980, Magyarország termőhelyi adottságait meghatározó tényezõk 1:100.000 méretarányú térképe II., Agrokémia és Talajtan 29, pp. $35-76$.

Vágás I., 1989, A belvíz elvezetése, Hidrológiai Közlöny 2. pp. 77-82.

Veres G. 2002, RBF neurális hálózat alkalmazása magasság meghatározására, Geodézia és Kartográfia 54, 7, pp. 25-30.

Verger A., Baret F., Weiss M., 2008, Performances of neural networks for deriving LAI estimates from existing CYCLOPES and MODIS products, Remote sensing of the Environment 112, pp. $2789-2803$.

Vilas L.G., Spyrakos E., Torres Palenzuela J.M., 2011, Neural network estimation of chlorophyll a from MERIS full resolution data for the coastal waters of Galician rias (NW Spain), Remote Sensing of Environment 115, pp. 524-535.

Villmann T., Merényi E. Hammer B., 2003, Neural Maps in Remote Sensing Image Analysis. Neural Networks, Special Issue on Self-Organizing Maps for Analysis of Complex Scientific Data 16, 3-4, pp. 389 - 403. 
Vízügy 2011, Vízügy Tájékoztató a 2010-2011 évi belvízi helyzetről (National Water Management Directorate, inland excess report of 2010-2011), 2011.02.02, http://www.vizugy.hu/print.php?webdokumentumid=280 [12-04-2011].

Widrow B \& Lehr M.A., 1995, Perceptrons, Adalines, and Backpropagation, In: Arbib M.A. (ed.) Handbook of brain theory and neural networks pp. 719-724.

Yang Y, \& Rosenbaum M.S., 2001, Artificial networks linked to GIS for determining sedimentology in harbours, Journal of Petroleum Science and Engineering, 29, pp. 213-220.

Yeh A.G-O. \& Li X., 2003, Simulation of development alternatives using neural networks, cellular automata, and GIS for urban planning, Photogrammetric Engineering \& Remote Sensing, Vol. 69, No. 9, pp. 1043-1052.

Zaletnyik P., 2007, Koordinátatranszformációk megoldása számítógépes algebra és neurális hálózatok felhasználásával, Ph.D. Dissertation, Budapesti Müszaki és Gazdaságtudományi Egyetem, p. 115.

Zhou W, 1999, Verification of the nonparametric characteristics of backpropagation neural networks for image classification, IEEE Transactions on geoscience and remote sensing, Vol. 37, No. 2, pp. 771-779.

Zurada J.M., 1992, Introduction to Artificial Neural Systems. New York: West Publishing Company 683 p. 


\section{Summary}

Due to its geographic position and climate, the Great Hungarian Plain is under continuous threat of droughts and floods. The year 2010 was one of the wettest years ever in Hungary. In the period October 2009 - December 2010, on the Great Hungarian Plain, $1149 \mathrm{~mm}$ precipitation fell, which corresponds to a yearly precipitation of $919 \mathrm{~mm}$, while the long term average yearly precipitation is $489 \mathrm{~mm}$ (in Szeged). The extreme precipitation caused exceptionally large areas to be flooded by inland excess water. The maximum total flooded area during this 15-months period was 355000 ha on December 9, 2010 and the estimated financial damage to the agricultural sector alone exceeded 500 million Euros. Together with the consequential damage like soil degradation, inland excess water is one of the most severe natural hazards in the Carpathian basin. To be able to prevent or reduce damage due to inland excess water it is necessary to understand why and where it occurs.

There is no formal or official English word to describe the hydrological process that is the main topic of the dissertation. Inland excess water is a translation of the Hungarian word belviz and will be used throughout this work. Although inland excess water got most scientific attention in Hungary, the phenomenon is not limited to this geographic region. For example, in China, India, Italy, Germany, the Netherlands, Serbia, Romania, and Russia it occurs as well. The large number of definitions of inland excess water used in literature reflects the many scientific fields that deal with inland excess water research. Every field e.g. water management, agriculture, ecology, landscape planning or economics defines the phenomenon from its own perspective. My general working definition that is used throughout this work is the following:

Inland excess water is water that temporarily remains in local depressions because of a combination of a surplus of water due to lack of runoff, insufficient evaporation and low infiltration capacity of the soil or because of upwelling of groundwater.

Different genetic types of inland excess water can be distinguished: (1) The vertical type, which is caused by the upwards push of groundwater, (2) the horizontal type, that occurs due to precipitation and/or melting water that accumulates in local depressions because there is insufficient runoff, evaporation and/or infiltration, and (3) the type that occurs due to inland excess water that is transported from other areas towards a main river, but queues up in front of a pumping station because the station does not have enough pumping capacity.

Inland excess water is caused by a multitude of interrelated factors. They can be split into two groups; static factors that are stable over a period of decades or longer, such as relief and soil, and dynamic factors, which change within hours or days, like meteorology and groundwater level. Relief influences the runoff: water may collect in local depressions. Soil characteristics determine the infiltration and storage capacity. The amount of precipitation, as source of inland excess water is part of the meteorological factor. Other meteorological components like temperature and water vapour influence the evaporation rate. High groundwater levels may cause floodings, but can also 
prevent water from infiltration in the soil. Often anthropogenic factors strongly affect the formation of inland excess water. This can be due to the obstruction of runoff (e.g. by buildings, roads or levees) and by reducing infiltration (e.g. due to paved surfaces), or by decreasing the chance of inundations due to for example the construction of channels and reservoirs.

Damages caused by inland excess water vary in time and space. In some years, over $10 \%$ of the agricultural land is flooded, while in other years there is hardly any damage. Some areas suffer from inland excess water in one year, while in other years, at the same place severe drought occurs. This complicates the possibilities to find solutions for the problem. The spatial pattern of inland excess water is also heterogeneous. Due to the spatial variation of the interrelated factors, areas that are never inundated can be found close to areas that are often under water.

To analyse the complex problem of inland excess water, it is important to understand its spatial and temporal distribution. This is done in two ways: (1) By mapping the spatial and temporal distribution based on in situ or remotely sensed observations, and (2) by estimating the impact of a selection of principle factors and weighing those using experimentally derived coefficients. Most studies have tried to identify the above factors and combined them using regression functions or other linear statistical methods. These methods have the disadvantage that they cannot deal with the nonlinear and complex functional relationships between those factors. Here, we present a different approach to identify and forecast inland excess water inundations using artificial neural networks (ANN) combined with geographic information systems (GIS). This approach has many advantages. First, it is independent of the statistical distribution of the data and there is no need to define the weight of the individual factors. Neural networks allow the target classes to be defined in relation to their distribution in the corresponding domain of each data source, and therefore the integration of remote sensing and GIS data is very convenient. Furthermore, ANNs are capable of incorporating uncertainty, incomplete data, incorrect sampling, multicollinearity between variables, spatial or temporal autocorrelation, and insignificance of single variables. These are common in geographic analysis, but especially in inland excess water research due to the fuzzy nature of the boundaries of the inundations and the complex interrelations between the factors.

To facilitate the efficient application of classification of inland excess water occurrences by artificial neural networks, an integrated GIS - ANN framework was created using a combination of ArcGIS, a geographic information system, Matlab, a mathematical modelling software and Python, an open source programming language.

The framework was created to handle input data, intermediate results and output data in a flexible way in both ArcGIS and Matlab. In this way, it is possible to create the data files, test different network settings, perform training and simulation, and evaluate and visualize the training and simulation results efficiently. All steps are executed from within the GIS and no direct user interaction with the ANN software is needed. 
The framework was developed and evaluated with data from a $20 \mathrm{~km}^{2}$ area near Szeged, Hungary. The area is suitable for inland excess water research for two main reasons: (1) the soils in the area show extreme mechanical properties. The bad permeability characteristics combined with the very flat terrain with large local depressions without runoff, result in high vulnerability to inland excess water accumulation and (2) the Department of Physical Geography and Geoinformatics has a long standing inland excess water research program in the area. This means that lots of data and knowledge about the area are available. Furthermore, the area is close to the airport of Szeged from where the data acquisition campaigns are executed. Since inland excess water is a phenomenon with strong temporal characteristics, it is important to acquire data for research in time.

Five input data sets were created to be used in the framework: (1) Colour infrared (CIR) images collected with an in-house developed acquisition system based on a MS3100 digital camera, (2) a 1 m resolution LIDAR based digital elevation model, (3) a 1:25 000 scale soil database, (4) a database of anthropogenic objects in the area (channels, roads, buildings and oil wells), and (5) inland excess water ground truth data collected with hand-held GPS systems. Other input data that may influence the formation of inland excess water were not incorporated for several reasons. First, soil measurement showed everywhere in the area poor permeability characteristics, and differences in other soil characteristics were also minimal. Therefore, the soil is considered homogeneous in the study areas. The lithology is also considered to be homogeneous throughout the area. A groundwater-precipitation-evapotranspiration measuring station in the study area provides hourly data of many parameters. These parameters show that the precipitation, evaporation and infiltration result in a surplus of water. Vegetation is not homogeneously distributed over the area, but was not introduced as a separate input layer to the network, because its distribution is represented by the colour infrared images.

Many simulations have been executed. These simulations were cross-referenced with the training data set and results of other traditional classification methods. Four simulations were executed to evaluate the influence of the different input layers. Each simulation was executed with a different set of input layers, but with the same neural network settings. The simulations have been performed on data from the training area only, since only there, it is possible to compare the results with ground truth data.

The ANN - GIS framework is a calculation intensive approach. Experiments have been executed to determine possibilities for performance improvements. It was found that there is an exponential relationship between the time needed for training of the network and the amount of data in the training data set. It was also found that there is an exponential relationship between the time needed for training and the amount of data that is written to the computer's memory. Based on these observations, the Data reductions factor was developed and the Memory reduction function (of Matlab) was used. 
From the simulation results, it can be concluded that - in general - adding more layers gives better results. Including all input layers (except for soil) results in the highest overall accuracy and Cohen's Kappa value. Including the soil layer into the simulation slightly decreases the accuracy. This is due to its limited influence on the spatial distribution of inland excess water in this study area. In all cases, the ANN classification gives better results than the traditional Maximum Likelihood and minimum distance classifications. Improving the classification result is possible by adding additional information to the training set. Adding these extra input layers is only possible with the ANN approach since the additional layers are not compatible with the remote sensing data, and therefore it is not possible to improve the maximum likelihood method in this way. 


\section{9 Összefoglalás}

Földrajzi helyzetének és klímájának következtében az Alföld az aszály és az áradások folytonos veszélyének van kitéve. A 2010-es esztendő az egyik legcsapadékosabb év volt Magyarországon, melyet valaha mértek. Az Alföldön, 2009 októbere és 2010 decembere között 1149 mm csapadék hullott, ami éves szinten 919 mm-t jelentett Szegeden a 489 mm-es többéves átlaghoz képest. Az extrém csapadékmennyiség kivételesen nagy belvízelöntéseket okozott. A vízzel borított területek maximális kiterjedésüket ebben a 15 hónapos időszakban 2010. december 9-én érték el 355000 haral, ami csak a mezőgazdasági szektorban több mint 500 millió eurós kárt okozott. A belvízelöntés, a következtében kialakuló károkkal együtt - mint amilyen például a talajdegradáció - a Kárpátmedencében az egyik leggyakoribb természeti katasztrófa. Belvíz okozta károk megelőzése, illetve csökkentése érdekében fontos, hogy megértsük a kialakulásának okait és ismerjük az előfordulásait.

A disszertáció fó témáját adó hidrológiai jelenségre nem létezik hivatalos angol elnevezés. Az Inland excess water kifejezés - amit a dolgozatban mindvégig használok - a magyar Belvíz szó fordítása. Habár a belvíz jelenség tudományos vizsgálatára Magyarországon vetül a legnagyobb figyelem, annak előfordulása nem korlátozódik erre a földrajzi régióra. Megjelenik például Kínában, Indiában, Olaszországban, Németországban, Hollandiában, Szerbiában, Romániában és Oroszországban is. A szakirodalmakban fellelhető nagyszámú belvíz definíció a kutatásokban résztvevő számos tudományterület hatását mutatja, melyek mindegyike - mint például a vízgazdálkodás, mezőgazdaság, ökológia, tájtervezés vagy közgazdaságtan - saját szempontjai szerint közelít a problémához. A disszertációban használt saját általános definíció a következő:

A belvíz lokális mélyedésekben megjelenö idöszakos vízboritás, amelyet a lefolyás hiányából következö vízelesleg, az elégtelen párolgás, valamint a talaj alacsony vizelvezetési képességének kombinációja vagy a feláramló talajvíz okoz.

Különböző genetikai típusú belvizek különíthetők el: (1) A vertikális típus, melyet a feláramló talajvíz okoz; (2) a horizontális típus, amely az elégtelen lefolyás, párolgás és/vagy beszivárgás következtében a helyi mélyedésekben összegyülö csapadékból és/vagy olvadékvízböl jön létre; illetve (3) a folyók irányába más területekről érkező, az átemelő állomások elégtelen kapacitásának következtében azok előtt összegyülekező belvíz.

A belvíz több tényező egymásra hatása következtében alakul ki. Ezeket két csoportba sorolhatjuk: a statikus tényezők évtizedeken vagy még hosszabb időintervallumon át is stabilak maradnak, mint amilyen a relief és a talaj; a dinamikus tényezők azonban néhány órán vagy napon belül is változhatnak, mint például a meteorológiai viszonyok és a talajvízszint. A relief befolyásolja a lefolyást: olyan lokális mélyedések alakulhatnak ki, melyekben összegyülik a víz. A talajtulajdonságok meghatározzák a beszivárgást és a tárolási kapacitást. A csapadék mennyisége mint a belvíz forrása - a meteorológiai tényező része. Az egyéb meteorológiai összetevők - mint a hőmérséklet vagy a páratartalom - a párolgási sebességet befolyásolják. A magas talajvízszint 
nemcsak elöntéseket okozhat, de akadályozhatja a talajba szivárgást is. Gyakran antropogén tényezők gyakorolnak nagy hatást a belvízképződésre. Ez történhet a lefolyás akadályozásával (pl. épületek, utak, gátak által), a beszivárgás csökkentésével (pl. aszfaltozott felületeken) vagy ellenkezőleg, a víz összegyülekezési esélyének csökkentésével (pl. csatornák és tározók építése által).

A belvíz okozta károk térben és időben egyaránt változatosak. Bizonyos években akár a mezőgazdasági területek $10 \%$-a is víz alá kerül, míg máskor alig jelentkeznek károk. Néhány területet egyik évben elönt a víz, míg ugyanott egy másik évben komoly szárazság tapasztalható. Mindez megnehezíti a probléma megoldását. A belvíz térbeli mintázata is heterogén. A befolyásoló tényezők térbeli változatossága következtében egymás közelében találhatunk soha el nem öntött és gyakran víz alá kerülö terülteket.

A komplex belvíz probléma elemzéséhez fontos megérteni annak térbeli és időbeli eloszlását. Ez két módon valósítható meg: (1) a térbeli és időbeli eloszlás terepi (in situ) vagy távérzékelt adatokon alapuló térképezésével; és (2) a kiválasztott, legfontosabb befolyásoló tényezők hatásainak becslésével, majd azok tapasztalati együtthatókkal történő súlyozásával. A legtöbb kutatás megpróbálta a fenti tényezők azonosítását és kombinálását regressziós függvények vagy egyéb lineáris statisztikai módszerek segítségével megoldani. Ezek a módszerek azonban nem képesek kezelni a tényezők közötti nem-lineáris és komplex funkcionális kapcsolatokat. Jelen kutatás egy ettől eltérő megközelítést mutat be: a belvízelöntések azonosítására és előrejelzésére a mesterséges neurális hálózatokat (ANN) a földrajzi információs rendszerekkel (GIS) kombinálja. Ennek a módszernek számos előnye van. Először is független az adatok statisztikai eloszlásától és nincs szükség az egyes tényezők súlyának definiálására. A neurális hálózatok lehetővé teszik a célcsoportok azonosítását minden egyes kapcsolódó adatforrás értelmezési tartományának (domain) megfelelően, így a távérzékelt és GIS adatok integrációja kényelmesen megoldható. Az ANN képes továbbá a belső bizonytalanságok, a hiányos adatok, a helytelen mintavétel, a változók közötti többszörös kollinearitás, a tér- vagy időbeli autokorreláció és az egyedi változók inszignifikanciájának kezelésére. A felsoroltak a földrajzi elemzések során általánosan előfordulnak, a belvíz kutatásokban azonban - az elöntések fuzzy határai és az előidéző tényezők komplex belső kapcsolatai miatt - különösen jelentősek.

A belvíz előfordulások neurális hálózatokkal történő hatékony osztályozásához olyan keretrendszert kellett létrehozni, amelyet az ArcGIS földrajzi információs rendszer, a Matlab matematikai modellező szoftver és a Python nyílt forrású programnyelv épít fel.

A keretrendszert úgy alkottam meg, hogy a bemenő, köztes és kimenő adatokat egyaránt rugalmasan kezelje ArcGIS-ben és Matlab-ban. Ily módon hatékonyan hozhatunk létre adatállományokat, tesztelhetünk különböző hálózati beállításokat, futtathatunk tréning és szimulációs lépéseket, illetve értékelhetjük és vizualizálhatjuk a tréning és szimulációs 
eredményeket. Minden egyes lépés a GIS programból indítható, így nincs szükség közvetlen felhasználói beavatkozásra az ANN rendszerben.

A keretrendszer fejlesztése és tesztje egy Szegedhez közeli 20 km2-es terület adatai alapján történt. A mintaterület kiválasztásában két fő tényező játszott szerepet: (1) a terület talajai extrém mechanikai tulajdonságokkal jellemezhetők. A rossz áteresztőképesség (permeábilitás) a nagyrészt sík felszínen nagy kiterjedésü, lefolyástalan lokális mélyedésekkel párosul, aminek eredményeként a belvíz összegyülekezésének valószínűsége igen nagy. (2) A Természeti Földrajzi és Geoinformatikai Tanszék hosszú idő óta végez itt belvízkutatásokat, aminek eredményeképpen nagy mennyiségü adat és ismeret áll rendelkezésre a területről. A mintaterület emellett közel fekszik a szegedi repülőtérhez, ami a légi adatgyüjtés kiinduló állomása volt. Mivel a belvíz időben nagyon változékony jelenség, a kutatások szempontjából fontos a megfelelő idejű adatfelvételezés.

A keretrendszerben 5 különbözö input adatforrást használtunk: (1) színes-infravörös (CIR) légifelvételek, melyeket a tanszéki fejlesztésü - DuncanTech MS3100 digitális kamerára épülő légi adatgyüjtő rendszerünk szolgáltatott; (2) 1 méter felbontású. LIDAR alapú digitális domborzatmodell; (3) 1:25000 méretarányú talaj adatbázis; (4) a területen megtalálható antropogén objektumok (csatornák, utak, épületek és olajkutak) adatbázisa; és (3) kézi GPS eszközzel gyüjtött terepi referencia mérések adatai a belvízelöntésekről. Egyéb - a belvízképződést befolyásoló input adatok különféle okok miatt nem kerültek a rendszerbe. Elöször is a talajminták az egész területen rossz permeábilitást mutattak, amihez az egyéb talajtulajdonságok minimális eltérése is társult. Ennek megfelelően a talaj az egész területen homogénnek tekinthető. A földtani tényezők szintén homogénnek vehetők a mintaterületen. A talajvízszintet, csapadékot és páratartalmat mérő állomás órás felbontásban számos paraméterrel szolgált. Ezek a talajvíz, csapadék és párolgás adatok vízfelesleget mutattak a belvizes időszakokban. A vegetáció a területen nem homogén eloszlású, a rendszerben mégsem került bele külön input rétegként, ugyanis azt a színes-infravörös felvételek már reprezentálják.

Számos szimuláció került lefuttatásra. Ezek az eredmények keresztkorrelációt alkalmazva lettek összevetve a tréning adatokkal és a hagyományos osztályozási módszerekkel. A különböző input rétegek hatásának vizsgálata 4 szimulációt végrehajtva történt meg, melyek mindegyike más-más bemeneti rétegekkel, de azonos neurális hálózat beállításokkal futott le. A szimuláció csak a tréning területről származó adatokon lett végrehajtva, így az eredmény összehasonlítható a terepi felméréssel.

Az ANN - GIS keretrendszer számításigényes megoldás. A lehetséges teljesítményfokozás meghatározása kísérletekkel történt. A hálózat betanításához szükséges idő és a tréning adatok mennyisége között exponenciális kapcsolat került kimutatásra. Hasonló exponenciális kapcsolat volt megfigyelhető a tréning időtartalma és a számítógép memóriájába írt adatok mennyisége között. Ezen megfigyelések alapján került kidolgozásra az ún. Data reduction factor, illetve felhasználásra a Matlab Memory reduction funkciója. 
Általánosságban megállapítható, hogy minél több réteget használ a szimuláció, annál jobb az eredmény. Az összes bemenő réteg felhasználása eredményezi a legnagyobb pontosságot (Overall accuracy) és Cohen-féle Kappa értéket. Ez alól a talaj réteg jelent kivételt melynek használata negatív hatással van a pontosságra. Ez a jelenség, a talajtényező a mintaterületen a belvízképződésre gyakorolt korlátozott hatásával magyarázható. Az ANN osztályozás minden esetben jobb eredményt szolgáltatott, mint a hagyományos Maximum Likelihood és Minimum Distance klasszifikáció. Az osztályozás pontosságának növeléséhez a tréning állomány további információkkal történő bővítése vezethet. 
Annexes 


\section{Annex 1. Backpropagation algorithm}

In short and simplified, the steps and equations involved in the backpropagation training algorithm of a network with one input layer, one hidden layer and one output layer are as given below (After Freeman \& Skapura 1991 and Benediktsson et al. 1990). Note that the $h$ superscript stands for the quantities in the hidden layer, while the $o$ superscript refers to quantities in the output layer:

1. Apply the input vector $\mathbf{p}=\left(p_{1}, p_{2}, \ldots, p_{R}\right)^{T}$ to the network.

2. Calculate the net-input values to every $j^{\text {th }}$ neuron in the hidden layer:

$$
n_{j}^{h}=\sum_{i=1}^{R} w_{j i}^{h} p_{i}+b_{j}^{k}
$$

for $j=1, . ., \mathrm{S}$ and where $w_{j i}^{h}$ stands for the weights of the connection between the $i^{\text {th }}$ input and the $j^{\text {th }}$ neuron, and $b_{j}^{h}$ is the bias of the $j^{\text {th }}$ neuron.

3. Calculate the outputs of the hidden layer:

$$
a_{j}^{h}=f^{h}\left(n_{j}^{k}\right)
$$

for $j=1, . ., \mathrm{S}$ and where $f^{h}$ is the activation function of the hidden layer.

4. Calculate the net-input values to every $k^{\text {th }}$ neuron in the output layer:

$$
n_{k}^{o}=\sum_{j=1}^{R} w_{j}^{o} a_{j}^{k}+b_{k}^{o}
$$

for $k=1, \ldots, \mathrm{S}$.

5. Calculate the outputs:

$$
a_{k}=f^{o}\left(n_{k}^{o}\right)
$$

6. Calculate the error term for every $k^{\text {th }}$ neuron in the output layer:

$$
\delta_{k}^{o}=\left(y_{k}-a_{k}^{o}\right)\left(f^{o}\right)^{\prime}\left(n_{k}^{o}\right)
$$

for $k=1, \ldots, \mathrm{S}$ and where $y_{k}$ is the desired output value, and $a_{k}^{o}$ is the actual output value, and $\left(f^{o}\right)^{\prime}$ denotes the first derivative of the activation function of the output layer. 
7. Calculate the error terms for the $\mathrm{j}^{\text {th }}$ neurons in the hidden layer (before updating the weights of the output layer):

$$
\delta_{j}^{h}=\left(f^{h}\right)^{\prime}\left(n_{j}^{h}\right) \sum_{k=1}^{S} \delta_{k}^{o} w_{k j}^{o}
$$

8. Update the weights of the output layer, using the steepest descent gradient method (Gurney 1991), which is an iterative version of the simple least-squares method (Freeman \& Skapura 1991):

$$
\left(w_{k j}^{o}\right)_{n e w}=\left(w_{k j}^{o}\right)_{o l d}+\eta \delta_{k}^{o} a_{j}^{h}
$$

where $\eta$ is the learning rate. The performance of the algorithm is very sensitive to the proper setting of the learning rate; if the learning rate is too high, the algorithm may oscillate, if it is too small, the algorithm will take too long to converge (Amini 2008).

9. Update the weights of the hidden layer:

$$
\left(w_{j i}^{h}\right)_{n e w}=\left(w_{j i}^{h}\right)_{o l d}+\eta \delta_{j}^{h} p_{i}
$$

10. Calculate the error term (called the Generalized Data Rule) which is the sum of the squares of the errors for all output units:

$$
E=\frac{1}{2} \sum_{k=1}^{S^{o}} \delta_{k}^{2}
$$

where $\delta_{k}=y_{k}-a_{k}$, which is the difference between the requested and the actual output.

When this error is smaller than a certain threshold, the training is stopped and the weights are fixed. 


\section{Annex 2 Representativity of the subsamples}

The subsets that result from the data reduction algorithm (see $\S 5.6$ ) have been statistically tested to verify if they are representative of the original data sets. The results for band 1 of the colour infrared image are given, because this is the input layer with the largest variation, and therefore with the largest change to be misrepresented by the sub-sample set. The Data reduction factor column specifies the size of the reduction, where 1 means that the original data set was used.

\begin{tabular}{|c|c|c|c|c|c|c|}
\hline $\begin{array}{c}\text { Data } \\
\text { reduction } \\
\text { factor }\end{array}$ & Min & Max & Mean & $\begin{array}{c}\text { Standard } \\
\text { deviation }\end{array}$ & $\begin{array}{c}z-\text { test } \\
\text { result } *\end{array}$ & $\begin{array}{c}K S-\text { test } \\
\text { result** }\end{array}$ \\
\hline 1 & 2 & 204 & 72,0625 & 16,1894 & $\mathrm{~h}=0$ & $\mathrm{~h}=0$ \\
\hline 2 & 2 & 203 & 72,0620 & 16,1923 & $\mathrm{~h}=0$ & $\mathrm{~h}=0$ \\
\hline 4 & 7 & 203 & 72,0560 & 16,1906 & $\mathrm{~h}=0$ & $\mathrm{~h}=0$ \\
\hline 5 & 2 & 204 & 72,0525 & 16,1877 & $\mathrm{~h}=0$ & $\mathrm{~h}=0$ \\
\hline 10 & 2 & 203 & 72,0598 & 16,1845 & $\mathrm{~h}=0$ & $\mathrm{~h}=0$ \\
\hline 100 & 15 & 180 & 72,1335 & 16,1908 & $\mathrm{~h}=0$ & $\mathrm{~h}=0$ \\
\hline
\end{tabular}

* Matlab's ztest $(\mathrm{x}, \mathrm{m})$ function performs a $z$-test of the null hypothesis that data in the vector $\mathrm{x}$ are a random sample from a normal distribution with mean $m$ and standard deviation sigma, against the alternative that the mean is not $m$. The result of the test is returned in $h . h=1$ indicates a rejection of the null hypothesis at the $5 \%$ significance level. $\mathrm{h}=0$ indicates a failure to reject the null hypothesis at the 5\% significance level (Matlab online help).

** Matlab's kstest2(x1, $\mathrm{x} 2)$ function performs a two-sample Kolmogorov-Smirnov test to compare the distributions of the values in the two data vectors $x 1$ and $x 2$. The null hypothesis is that $x 1$ and $\mathrm{x} 2$ are from the same continuous distribution. The alternative hypothesis is that they are from different continuous distributions. The result $\mathrm{h}$ is 1 if the test rejects the null hypothesis at the 5\% significance level; 0 otherwise (Matlab online help). 


\section{Annex 3. Performance measurements}

Individual time measurements for a network with 9 input layers. Activation functions are: logsig, pureline and the training method is trainlm

\begin{tabular}{|c|c|c|c|c|}
\hline $\begin{array}{l}\text { Data reduction } \\
\text { factor }\end{array}$ & $\begin{array}{l}\text { Memory reduction } \\
\text { factor }\end{array}$ & $\begin{array}{c}\text { Number of } \\
\text { hidden } \\
\text { neurons }\end{array}$ & $\begin{array}{c}\text { Time for } 50 \\
\text { iterations (in sec) }\end{array}$ & $\begin{array}{l}\text { Time for } 1 \text { iteration } \\
\text { (in sec) }\end{array}$ \\
\hline 1 & 1 & 20 & \multicolumn{2}{|c|}{ Out of memory } \\
\hline 2 & 1 & 20 & \multicolumn{2}{|c|}{ Out of memory } \\
\hline 3 & 1 & 20 & \multicolumn{2}{|c|}{ Out of memory } \\
\hline 20 & 1 & 20 & 75 & 3,75 \\
\hline 1 & 2 & 20 & \multicolumn{2}{|c|}{ Out of memory } \\
\hline 2 & 2 & 20 & \multicolumn{2}{|c|}{ Out of memory } \\
\hline 3 & 2 & 20 & \multicolumn{2}{|c|}{ Out of memory } \\
\hline 1 & 3 & 20 & \multicolumn{2}{|c|}{ Out of memory } \\
\hline 2 & 3 & 20 & \multicolumn{2}{|c|}{ Out of memory } \\
\hline 3 & 3 & 20 & 570 & 11,4 \\
\hline 4 & 3 & 20 & 424 & 8,48 \\
\hline 5 & 3 & 20 & 335 & 6,7 \\
\hline 7 & 3 & 20 & 219 & 4,38 \\
\hline 8 & 3 & 20 & 189 & 3,78 \\
\hline 10 & 3 & 20 & 143 & 2,42 \\
\hline 20 & 3 & 20 & 68 & 1,36 \\
\hline
\end{tabular}

\begin{tabular}{|c|c|c|c|c|}
\hline 4 & 3 & 20 & 424 & 8,48 \\
\hline 4 & 4 & 20 & 414 & 8,28 \\
\hline 4 & 5 & 20 & 390 & 7,8 \\
\hline 4 & 7 & 20 & 369 & 7,38 \\
\hline 4 & 10 & 20 & 356 & 7,12 \\
\hline 4 & 20 & 20 & 353 & 7,06 \\
\hline
\end{tabular}

\begin{tabular}{|c|c|c|c|c|}
\hline 4 & 3 & 8 & 249 & 4,98 \\
\hline 4 & 3 & 9 & 259 & 5,18 \\
\hline 4 & 3 & 10 & 275 & 5,5 \\
\hline 4 & 3 & 15 & 351 & 7,02 \\
\hline 4 & 3 & 20 & 424 & 8,48 \\
\hline 4 & 3 & 25 & 495 & 9,9 \\
\hline 4 & 3 & 30 & 594 & 11,88 \\
\hline
\end{tabular}

